\title{
Interception of the "Bycroft-Gowland" intermediate in the enzymatic macrocyclization of thiopeptides
}

Jonathan W. Bogart ${ }^{1}$, Nicholas J. Kramer ${ }^{1}$, Aneta Turlik ${ }^{2}$, Rachel M. Bleich ${ }^{1}$, Daniel S. Catlin ${ }^{3}$, Frank C. Schroeder ${ }^{4}$, Satish K. Nair ${ }^{3,5}$, R. Thomas Williamson ${ }^{6}$, K. N. Houk ${ }^{2}$, Albert A. Bowers ${ }^{1,7}$

${ }^{1}$ Division of Chemical Biology and Medicinal Chemistry, UNC Eshelman School of Pharmacy, University of North Carolina at Chapel Hill, Chapel Hill, North Carolina 27599, USA

${ }^{2}$ Department of Chemistry and Biochemistry, University of California, Los Angeles, California 90095, USA

${ }^{3}$ Department of Biochemistry, University of Illinois at Urbana-Champaign, Urbana, Illinois 61801

${ }^{4}$ Boyce Thompson Institute and Department of Chemistry and Chemical Biology, Ithaca, New York 14853, USA

${ }^{5}$ Center for Biophysics and Computational Biology, University of Illinois at Urbana-Champaign, Illinois 61801, USA

${ }^{6}$ Department of Chemistry and Biochemistry, University of North Carolina Wilmington, Wilmington, North Carolina 28403, USA

${ }^{7}$ Department of Chemistry, University of North Carolina at Chapel Hill, Chapel Hill, North Carolina 27599, USA

*e-mail: abower2@email.unc.edu

\section{Contents:}



2. Synthesis of Building Blocks......................................................................... 4-18

3. Solid Phase Peptide Synthesis................................................................... 18-19

4. Protein Expression and Purification............................................................... 18-19

5. General Information for Intramolecular Cyclization Assays with TbtD .........................20

6. Table S1 - Summary of Cyclizations with Variant Substrates....................................21

7. Figure S1 - Thiopeptides with 29-membered Macrocycles.........................................22

8. Figure S2 - Cyclization Assays with Thiazole-to-Oxazole Substitutions ................... 23-24

9. Figure S3 - Time Courses of (4) at pHs 8.5-10.5 ..............................................2

10. Synthesis and Isolation of ${ }^{13} \mathrm{C}$-Labeled Intermediate (6') and Thiopeptide (7') ........ 26-28

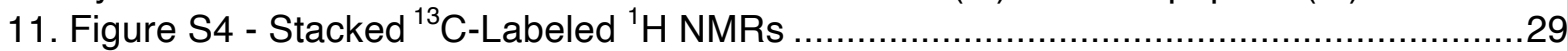

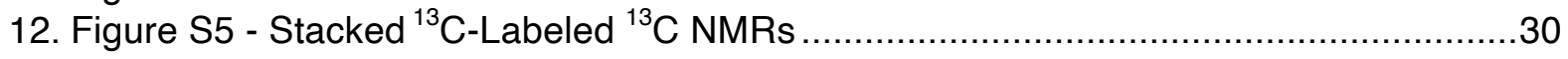

13. Figure S6 - Calculated NMR Shifts for Two Potential Intermediates ...............................

14. NMR Calculations ............................................................................... $31-50$

15. Figure S7 - DFT Calculations for Possible Aza-[4+2] Cycloaddition Mechanism .............51

16. DFT Calculations of Aza-[4+2] Reaction ..................................................... 52-88

17. Peptide Characterization ............................................................................ 89-94

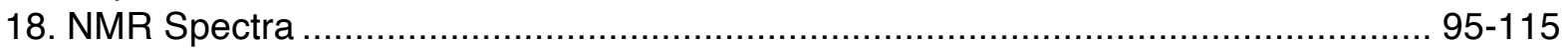




\section{General Information}

All reactions were carried out in an oven-dried round-bottom flask under an inert nitrogen atmosphere with stirring, unless indicated otherwise. Solvents, reagents, and chemical were purchased through Fisher Scientific ${ }^{\mathrm{TM}}$ and Millipore Sigma and used as received unless otherwise noted. Amino acids, their protected derivatives, and 1-hydroxybenzotriazole hydrate $\left(\mathrm{HOBt} \cdot \mathrm{H}_{2} \mathrm{O}\right)$ were purchased from Chem-Impex International, Inc. 1-Ethyl-3-(3dimethylaminopropyl)carbodiimide hydrochloride $(\mathrm{EDC} \cdot \mathrm{HCl})$ was purchased from ChemPep Inc.

Spectra for ${ }^{1} \mathrm{H}$ and ${ }^{13} \mathrm{C}$ NMR of amino acid building blocks were recorded at room temperature, unless otherwise noted, with a Varian Inova $400(400 \mathrm{MHz}$ and $100 \mathrm{MHz}$, respectively) or Varian Inova $500\left(500 \mathrm{MHz}\right.$ and $125 \mathrm{MHz}$, respectively) spectrometers. Spectra for ${ }^{1} \mathrm{H},{ }^{13} \mathrm{C}$, and ${ }^{13} \mathrm{C}-{ }^{13} \mathrm{C}$ COSY NMR of ${ }^{13} \mathrm{C}$-labeled peptides were recorded at room temperature, unless otherwise noted, with a Bruker $850(850 \mathrm{MHz}$ and $213 \mathrm{MHz}$, respectively) spectrometer. Chemical shifts are reported in $\delta(\mathrm{ppm})$ relative units to residual solvent peaks $\mathrm{CDCl}_{3}\left(7.26 \mathrm{ppm}\right.$ for ${ }^{1} \mathrm{H}$ and $77.0 \mathrm{ppm}$ for ${ }^{13} \mathrm{C}$ ) and DMSO- $d_{6}\left(2.50 \mathrm{ppm}\right.$ for ${ }^{1} \mathrm{H}$ and $39.5 \mathrm{ppm}$ for $\left.{ }^{13} \mathrm{C}\right)$. Splitting patterns are assigned as $\mathrm{s}$ (singlet), d (doublet), t (triplet), q (quartet), quint (quintet), $m$ (multiplet), dd (doublet of doublets), td (triplet of doublets), and dt (doublet of triplets). Coupling constants are reported as $\mathrm{Hz}$, which are followed by integration.

LCMS measurements were recorded using an Agilent 6520 Accurate-Mass Q-TOF ESI positive in high-resolution mode, $350{ }^{\circ} \mathrm{C}$ temperature and $250 \mathrm{~V}$ fragmentor, with a $100 \times 2.10 \mathrm{~mm}$ Kinetex® 2.6 A C8 100 Å column or a 50 x 2.1 mm Kinetex® 2.6 A C18 100 Å column; both were purchased from Phenomenex ${ }^{\circledR}$, Inc. Predicted masses were extracted to $\pm 5 \mathrm{ppm}$. Two methods were utilized.

\section{Method A:}

\begin{tabular}{ll} 
Time (min) & $\%$ Solvent B \\
$0-2$ & 2 \\
\hline $2-5$ & $2-45$ \\
$5-22$ & $45-60$ \\
\hline $22-23$ & $60-95$ \\
$23-24$ & 95 \\
$24-25$ & $95-2$
\end{tabular}




\begin{tabular}{ll} 
Method B: & \\
\hline Time (min) & $\%$ Solvent B \\
\hline $0-2$ & 2 \\
\hline $2-13$ & $2-98$ \\
\hline $13-15$ & 98
\end{tabular}

Microwave assisted peptide couplings were programmed and synthesized in a Biotage Initiatior+ Alstra $^{\mathrm{TM}}$ with Rink Amide ChemMatrix ${ }^{\circledR}$ purchased from Biotage. Solutions utilized were freshly prepared just before synthesis. Manual solid phase peptide synthesis was performed on a Mettler Toledo Bohdan MiniBlock ${ }^{\text {TM }}$ Compact Shaking and Washing station. Flash chromatography was performed on a Biotage Isolera ${ }^{\mathrm{TM}}$ system with ethyl acetate/hexanes or methanol/dichloromethane solvent systems. Analytical thin-layer chromatography was performed on a glass plate pre-coated with silica gel (Silica gel HL TLC Plates, glass backed, 250 um) purchased from Sorbent Technologies ${ }^{\circledR}$, Inc. Preparatory HPLC was performed in a Shimadzu UFLP CBM-20A with a dual channel wavelength detector at $220 \mathrm{~nm}$ and $254 \mathrm{~nm}$ with a LUNA $10 \AA \mathrm{C} 18(2) 100 \AA$, AXIA (Phenomenex ${ }^{\circledR}$, Inc.) semi-preparatory column with a $15 \mathrm{~mL} / \mathrm{min}$ flow rate. Purifications were carried out with a to solvent system (solvent $A-0.1 \%$ trifluoroacetic acid in water; $B-0.1 \%$ trifluoroacetic acid in acetonitrile). Analytical HPLC was performed with a dual channel wavelength detector at $254 \mathrm{~nm}$ and 220 or $250 \mathrm{~nm}$ on a Kinetex $10{ }^{\circledR} \mathrm{C} 18100 \AA$ (Phenomenex ${ }^{\circledR}$, Inc.) column with a $0.5 \mathrm{~mL} / \mathrm{min}$ flow rate.

\section{Method A:}

Time (min) \% Solvent B

\begin{tabular}{ll}
$0-2$ & 5 \\
$2-8$ & $5-35$ \\
\hline $8-23$ & $35-55$ \\
$23-25$ & $55-100$ \\
$25-28.5$ & 100 \\
$28.5-30$ & $100-5$ \\
$30-32$ & 5
\end{tabular}

\section{Method B:}

\begin{tabular}{ll} 
Time $(\boldsymbol{m i n})$ & $\%$ Solvent B \\
$0-2$ & 5 \\
\hline $2-25$ & $5-95$ \\
$25-27$ & 95 \\
\hline $27-28$ & $95-5$ \\
$28-30$ & 5
\end{tabular}




\begin{tabular}{ll} 
Method C: & \\
\hline Time $($ min) & $\%$ Solvent B \\
\hline $0-2$ & 5 \\
\hline $2-15$ & $5-95$ \\
\hline $15-18$ & 95 \\
\hline $18-19$ & $95-5$ \\
\hline $19-20$ & 5 \\
\hline
\end{tabular}

\section{Synthesis of Building Blocks}

(S)-2-(1-((((9H-fluoren-9-yl)methoxy)carbonyl)amino)-2-(tritylthio)ethyl)thiazole-4carboxylic acid (S1)<smiles>O=C(O)c1csc(C(C[SeH])NC(F)F)n1</smiles>

We have previously described the synthesis of compound $\mathbf{S 1} .{ }^{1}$ The ${ }^{1} \mathrm{H}$ and ${ }^{13} \mathrm{C}$ NMRs are in good agreement with that previously reported.

${ }^{1} \mathrm{H}$ NMR $\left(500 \mathrm{MHz}\right.$, DMSO- $\left.d_{6}\right) \delta 8.31(\mathrm{~d}, J=8.5 \mathrm{~Hz}, 1 \mathrm{H}), 8.26(\mathrm{~s}, 1 \mathrm{H}), 7.88(\mathrm{~d}, J=7.6 \mathrm{~Hz}, 2 \mathrm{H})$, $7.70(\mathrm{~d}, J=7.6 \mathrm{~Hz}, 2 \mathrm{H}), 7.39(\mathrm{dt}, J=8.0,4.2 \mathrm{~Hz}, 2 \mathrm{H}), 7.33(\mathrm{~d}, J=6.6 \mathrm{~Hz}, 12 \mathrm{H}), 7.30-7.21(\mathrm{~m}$, $5 \mathrm{H}), 4.53(\mathrm{td}, J=8.9,5.3 \mathrm{~Hz}, 1 \mathrm{H}), 4.34(\mathrm{~d}, J=7.1 \mathrm{~Hz}, 2 \mathrm{H}), 4.23(\mathrm{t}, J=7.0 \mathrm{~Hz}, 1 \mathrm{H}), 2.83(\mathrm{dd}, J=$ $12.7,9.6 \mathrm{~Hz}, 1 \mathrm{H}), 2.67$ (dd, $J=12.7,5.3 \mathrm{~Hz}, 1 \mathrm{H})$.

${ }^{13} \mathrm{C}$ NMR $\left(125 \mathrm{MHz}\right.$, DMSO- $\left.d_{6}\right) \delta 172.13,162.57,155.96,144.66,144.14,141.20,129.58$, 128.62, 128.10, 127.54, 127.52, 127.35, 125.69, 125.66, 120.59, 66.96, 66.17, 52.97, 47.11, 35.92.

LCMS ESI: $\mathrm{C}_{40} \mathrm{H}_{32} \mathrm{~N}_{2} \mathrm{NaO}_{4} \mathrm{~S}_{2}{ }^{+}[\mathrm{M}+\mathrm{Na}]^{+}$Exact Mass: 691.1696; Observed: 691.1689

\footnotetext{
${ }^{1}$ Wever, W. J.; Bogart, J. W.; Bowers, A. A. J. Am. Chem. Soc. 2016, 138, 13461
} 
(S)-2-(1-((((9H-Fluoren-9-yl)methoxy)carbonyl)amino)-2-methylpropyl)thiazole-4carboxylic acid (S2)

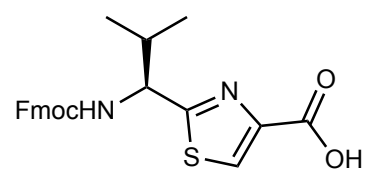

We have previously described the synthesis of compound $\mathbf{S 2} .{ }^{2}$ The ${ }^{1} \mathrm{H}$ and ${ }^{13} \mathrm{C}$ NMRs are in good agreement with that previously reported.

${ }^{1} \mathrm{H}$ NMR $\left(500 \mathrm{MHz}, \mathrm{DMSO}-\mathrm{d}_{6}\right) \delta 8.36(\mathrm{~d}, J=0.6 \mathrm{~Hz}, 1 \mathrm{H}), 8.22(\mathrm{~d}, J=8.6 \mathrm{~Hz}, 1 \mathrm{H}), 7.89(\mathrm{~d}, J=7.6$ $\mathrm{Hz}, 2 \mathrm{H}), 7.76-7.69(\mathrm{~m}, 2 \mathrm{H}), 7.44-7.38(\mathrm{~m}, 2 \mathrm{H}), 7.32(\mathrm{t}, J=7.4 \mathrm{~Hz}, 2 \mathrm{H}), 4.67$ (t, J = $7.9 \mathrm{~Hz}$, $1 \mathrm{H}), 4.41-4.28(\mathrm{~m}, 2 \mathrm{H}), 4.23(\mathrm{t}, J=7.1 \mathrm{~Hz}, 1 \mathrm{H}), 2.26(\mathrm{~h}, J=6.8 \mathrm{~Hz}, 1 \mathrm{H}), 0.93(\mathrm{~d}, J=6.7 \mathrm{~Hz}$, $3 \mathrm{H}), 0.86(\mathrm{~d}, \mathrm{~J}=6.7 \mathrm{~Hz}, 3 \mathrm{H})$.

${ }^{13} \mathrm{C}$ NMR $\left(125 \mathrm{MHz}\right.$, DMSO- $\left.d_{6}\right) \delta 173.67,162.08,156.14,146.85,143.72,140.71,128.34$, $127.63,127.03,125.24,120.10,65.66,58.99,46.69,32.18,19.36,18.21$

LCMS ESI: $\mathrm{C}_{23} \mathrm{H}_{23} \mathrm{~N}_{2} \mathrm{O}_{4} \mathrm{~S}^{+}[\mathrm{M}+\mathrm{H}]^{+}$Exact Mass: 423.1373; Observed: 423.1352

(S)-2'-(1-(((9H-Fluoren-9-yl)methoxy)carbonyl)amino)-2-methylpropyl)-[2,4'-bithiazole]-4carboxylic acid (S3)<smiles>CC(C)[C@H](NC(F)F)c1nc(-c2nc(C(=O)O)cs2)cs1</smiles>

We have previously described the synthesis of compound S3. ${ }^{2}$ The ${ }^{1} \mathrm{H}$ and ${ }^{13} \mathrm{C}$ NMRs are in good agreement with that previously reported.

${ }^{1} \mathrm{H}$ NMR $\left(400 \mathrm{MHz}\right.$, DMSO- $\left.d_{6}\right) \delta 8.23-8.13(\mathrm{~m}, 2 \mathrm{H}), 7.84(\mathrm{~d}, J=7.6 \mathrm{~Hz}, 2 \mathrm{H}), 7.68(\mathrm{dd}, J=7.9$, $3.9 \mathrm{~Hz}, 2 \mathrm{H}), 7.40-7.31(\mathrm{~m}, 2 \mathrm{H}), 7.26(\mathrm{t}, J=7.5 \mathrm{~Hz}, 2 \mathrm{H}), 4.65(\mathrm{t}, J=7.9 \mathrm{~Hz}, 1 \mathrm{H}), 4.36-4.25(\mathrm{~m}$, 2H), $4.19(\mathrm{t}, J=7.2 \mathrm{~Hz}, 1 \mathrm{H}), 2.22(\mathrm{q}, J=6.9 \mathrm{~Hz}, 1 \mathrm{H}), 0.91(\mathrm{~d}, J=6.7 \mathrm{~Hz}, 3 \mathrm{H}), 0.85(\mathrm{~d}, J=6.7 \mathrm{~Hz}$, $3 \mathrm{H})$.

${ }^{13} \mathrm{C}$ NMR $\left(125 \mathrm{MHz}\right.$, DMSO- $\left.d_{6}\right) \delta 174.97,162.21,162.19,156.19,148.10,147.31,143.71$, 140.72 , 128.91, 127.64, 127.04, 125.24, 125.18, 120.11, 117.77, 65.67, 58.95, 46.72, 32.30, $19.31,18.25$

LCMS ESI: $\mathrm{C}_{26} \mathrm{H}_{24} \mathrm{~N}_{3} \mathrm{O}_{4} \mathrm{~S}_{2}{ }^{+}[\mathrm{M}+\mathrm{H}]^{+}$Exact Mass: 506.1203; Observed: 506.1202 
(S)-2-(1-((((9H-Fluoren-9-yl)methoxy)carbonyl)amino)-3-(methylamino)-3oxopropyl)thiazole-4-carboxylic acid (S4)

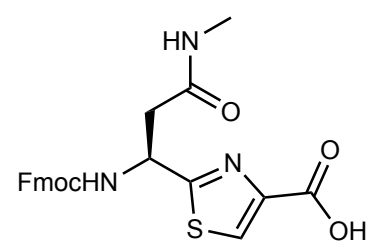

We have previously described the synthesis of compound $\mathbf{S 4} .{ }^{2}$ The ${ }^{1} \mathrm{H}$ and ${ }^{13} \mathrm{C}$ NMRs are in good agreement with that previously reported.

${ }^{1} \mathrm{H}$ NMR $\left(500 \mathrm{MHz}\right.$, DMSO- $\left.d_{6}\right) \delta 8.35(\mathrm{~s}, 1 \mathrm{H}), 8.23(\mathrm{~d}, J=8.1 \mathrm{~Hz}, 1 \mathrm{H}), 7.89(\mathrm{~d}, J=7.2 \mathrm{~Hz}, 3 \mathrm{H})$, 7.70 (dd, $J=7.6,4.5 \mathrm{~Hz}, 2 \mathrm{H}), 7.41$ (t, $J=7.8 \mathrm{~Hz}, 2 \mathrm{H}$ ), 7.32 (td, $J=7.6,2.5 \mathrm{~Hz}, 2 \mathrm{H}$ ), 5.26 (td, $J=$ 8.3, $5.4 \mathrm{~Hz}, 1 \mathrm{H}$ ), 4.39 (dd, $J=10.6,7.2 \mathrm{~Hz}, 1 \mathrm{H}), 4.32(\mathrm{dd}, J=10.6,6.8 \mathrm{~Hz}, 1 \mathrm{H}), 4.24(\mathrm{t}, J=6.9$ $\mathrm{Hz}, 1 \mathrm{H}), 2.86(\mathrm{dd}, J=15.2,5.4 \mathrm{~Hz}, 1 \mathrm{H}), 2.70(\mathrm{dd}, J=15.1,8.6 \mathrm{~Hz}, 1 \mathrm{H}), 2.57$ (d, J = 4.5 Hz, 3H). ${ }^{13} \mathrm{C}$ NMR $\left(125 \mathrm{MHz}\right.$, DMSO- $\left.d_{6}\right) \delta 174.09,169.48,162.50,156.04,147.32,144.27,144.12$, 141.22, 129.21, 128.12, 127.59, 127.56, 125.68, 125.64, 120.61, 66.14, 50.77, 47.15, 26.03.

LCMS ESI: $\mathrm{C}_{23} \mathrm{H}_{22} \mathrm{~N}_{3} \mathrm{O}_{5} \mathrm{~S}^{+}[\mathrm{M}+\mathrm{H}]^{+}$Exact Mass: 452.1275; Observed: 452.126

(S)-2-(1-((((9H-Fluoren-9-yl)methoxy)carbonyl)amino)-2-phenylethyl)thiazole-4-carboxylic acid (S5)<smiles>O=C(O)c1csc([C@H](Cc2ccccc2)NC(F)F)n1</smiles>

We have previously described the synthesis of compound $\mathbf{5 5} .{ }^{2}$ The ${ }^{1} \mathrm{H}$ and ${ }^{13} \mathrm{C}$ NMRs are in good agreement with that previously reported.

${ }^{1}$ H NMR (400 MHz, DMSO- $\left.d_{6}\right) \delta 8.35(\mathrm{~d}, J=14.9 \mathrm{~Hz}, 2 \mathrm{H}), 7.88(\mathrm{~d}, J=7.5 \mathrm{~Hz}, 2 \mathrm{H}), 7.61(\mathrm{t}, J=$ $7.4 \mathrm{~Hz}, 2 \mathrm{H}$ ), 7.41 (t, J=7.5 Hz, 2H), $7.36-7.25(\mathrm{~m}, 6 \mathrm{H}), 7.24-7.17(\mathrm{~m}, 1 \mathrm{H}), 5.05$ (ddd, J = 10.9, 8.6, 4.3 Hz, 1H), 4.28 (dd, $J=10.5,7.2 \mathrm{~Hz}, 1 \mathrm{H}), 4.22(\mathrm{dd}, J=10.5,6.8 \mathrm{~Hz}, 1 \mathrm{H}), 4.15(\mathrm{t}, J=7.0$ $\mathrm{Hz}, 1 \mathrm{H}), 3.38(\mathrm{~d}, J=4.4 \mathrm{~Hz}, 1 \mathrm{H}), 3.34(\mathrm{~d}, J=4.5 \mathrm{~Hz}, 2 \mathrm{H}), 3.06(\mathrm{dd}, J=13.8,10.9 \mathrm{~Hz}, 1 \mathrm{H})$.

${ }^{13} \mathrm{C}$ NMR $\left(100 \mathrm{MHz}, \mathrm{CDCl}_{3}\right) \delta \mathrm{ppm} 172.91,164.20,155.81,146.41,143.77,141.45,135.97$, 129.46, 128.90, 127.88, 127.36, 127.22, 127.21, 125.17, 120.14, 67.21, 54.41, 47.25, 41.50

LCMS ESI: $\mathrm{C}_{27} \mathrm{H}_{23} \mathrm{~N}_{2} \mathrm{O}_{4} \mathrm{~S}^{+}[\mathrm{M}+\mathrm{H}]^{+}$Exact Mass: 471.1373; Observed: 471.1371 
(R)-2-(1-((((9H-Fluoren-9-yl)methoxy)carbonyl)amino)-2-(tritylthio)ethyl)oxazole-4carboxylic acid (S6)



We have previously described the synthesis of compound $\mathbf{S 6} .{ }^{2}$ The ${ }^{1} \mathrm{H}$ and ${ }^{13} \mathrm{C}$ NMRs are in good agreement with that previously reported.

${ }^{1} \mathrm{H}$ NMR $(500 \mathrm{MHz} \text {, DMSO-d })_{6} \delta 8.66(\mathrm{~s}, 1 \mathrm{H}), 8.15(\mathrm{~d}, J=8.5 \mathrm{~Hz}, 1 \mathrm{H}), 7.88(\mathrm{~d}, J=7.5 \mathrm{~Hz}, 2 \mathrm{H})$, $7.75-7.64(\mathrm{~m}, 2 \mathrm{H}), 7.39(\mathrm{tt}, J=7.7,3.2 \mathrm{~Hz}, 2 \mathrm{H}), 7.37-7.28(\mathrm{~m}, 12 \mathrm{H}), 7.28-7.22(\mathrm{~m}, 4 \mathrm{H}), 4.47$ $(\mathrm{td}, J=8.6,6.2 \mathrm{~Hz}, 1 \mathrm{H}), 4.35-4.24(\mathrm{~m}, 2 \mathrm{H}), 4.22(\mathrm{t}, J=7.1 \mathrm{~Hz}, 1 \mathrm{H}), 2.78(\mathrm{dd}, J=12.7,8.9 \mathrm{~Hz}$, $1 \mathrm{H}), 2.66$ (dd, $J=12.7,6.3 \mathrm{~Hz}, 1 \mathrm{H})$.

${ }^{13} \mathrm{C}$ NMR $\left(125 \mathrm{MHz}\right.$, DMSO- $\left.d_{6}\right) \delta 163.47,162.32,155.89,145.84,144.58,144.17,144.11$, $141.17,133.57,129.56,128.62,128.11,128.09,127.52,127.38,125.71,120.57,66.96,66.26$, 48.87, 47.04, 34.32.

LCMS ESI: $\mathrm{C}_{40} \mathrm{H}_{32} \mathrm{~N}_{2} \mathrm{NaO}_{5} \mathrm{~S}^{+}[\mathrm{M}+\mathrm{Na}]^{+}$Exact Mass: 675.1924 ; Observed: 675.1928

(S)-2'-(1-((((9H-Fluoren-9-yl)methoxy)carbonyl)amino)-2-methylpropyl)-[2,4'-bioxazole]-4carboxylic acid (S7)<smiles>CC(C)[C@H](NC(F)F)c1nc(-c2nc(C(=O)O)co2)co1</smiles>

We have previously described the synthesis of compound $\mathbf{S 7} .{ }^{3}$ The ${ }^{1} \mathrm{H}$ and ${ }^{13} \mathrm{C}$ NMRs are in good agreement with that previously reported.

${ }^{1}$ H NMR (500 MHz, DMSO- $\left.d_{6}\right) \delta 8.91(\mathrm{~s}, 1 \mathrm{H}), 8.85(\mathrm{~s}, 1 \mathrm{H}), 8.19(\mathrm{~d}, J=8.5 \mathrm{~Hz}, 1 \mathrm{H}), 7.87(\mathrm{~d}, J=$ $7.6 \mathrm{~Hz}, 2 \mathrm{H}), 7.73$ (t, $J=7.6 \mathrm{~Hz}, 2 \mathrm{H}), 7.39$ (t, $J=7.5 \mathrm{~Hz}, 2 \mathrm{H}), 7.31$ (td, $J=7.5,2.3 \mathrm{~Hz}, 2 \mathrm{H}), 4.59$ $(\mathrm{t}, J=8.2 \mathrm{~Hz}, 1 \mathrm{H}), 4.36-4.28(\mathrm{~m}, 2 \mathrm{H}), 4.23(\mathrm{t}, J=7.1 \mathrm{~Hz}, 1 \mathrm{H}), 2.24$ (hept, $J=6.9 \mathrm{~Hz}, 1 \mathrm{H}), 0.98$ (d, J=6.7 Hz, 3H), $0.85(\mathrm{~d}, J=6.7 \mathrm{~Hz}, 3 \mathrm{H})$.

\footnotetext{
${ }^{2}$ Bogart, J. W.; Bowers, A. A. J. Am. Chem. Soc. 2019, 141, 1842-1846
} 
${ }^{13} \mathrm{C}$ NMR (125 MHz, DMSO- $\left.d_{6}\right) \delta 165.53,162.26,156.63,155.48,145.57,144.21,141.19$, $141.18,141.08,134.75,129.42$, 128.10, 127.51, 125.75, 120.55, 66.25, 55.52, 47.14, 31.45, 19.47, 19.15 .

LCMS ESI: $\mathrm{C}_{26} \mathrm{H}_{24} \mathrm{~N}_{3} \mathrm{O}_{6}{ }^{+}[\mathrm{M}+\mathrm{Na}]^{+}$Exact Mass: 474.1660; Observed: 474.1662

Methyl (S)-2-(1-((tert-butoxycarbonyl)amino)-2-methylpropyl)oxazole-4-carboxylate (S8)<smiles>COC(=O)c1coc(C(NC(=O)OC(C)(C)C)C(C)C)n1</smiles>

We have previously described the synthesis of compound $\mathbf{S 8} .{ }^{3}$ The ${ }^{1} \mathrm{H}$ and ${ }^{13} \mathrm{C}$ NMRs are in good agreement with that previously reported.

${ }^{1} \mathrm{H}$ NMR $\left(500 \mathrm{MHz}, \mathrm{CDCl}_{3}\right) \delta 8.19(\mathrm{~s}, 1 \mathrm{H}), 5.30(\mathrm{~d}, J=9.3 \mathrm{~Hz}, 1 \mathrm{H}), 4.80(\mathrm{dd}, J=9.4,6.0 \mathrm{~Hz}, 1 \mathrm{H})$, $3.92(\mathrm{~s}, 3 \mathrm{H}), 2.20(\mathrm{~h}, J=6.9 \mathrm{~Hz}, 1 \mathrm{H}), 1.43(\mathrm{~s}, 9 \mathrm{H}), 0.92(\mathrm{t}, J=7.5 \mathrm{~Hz}, 6 \mathrm{H})$.

${ }^{13} \mathrm{C}$ NMR $\left(125 \mathrm{MHz}, \mathrm{CDCl}_{3}\right) \delta 165.18,161.58,155.36,143.83,133.16,80.03,54.26,52.22,32.93$, 28.27, 18.68, 17.95 .

LCMS ESI: $\mathrm{C}_{14} \mathrm{H}_{22} \mathrm{~N}_{2} \mathrm{NaO}_{5}{ }^{+}[\mathrm{M}+\mathrm{Na}]^{+}$Exact Mass: 321.1421 ; Observed: 321.1425

(S)-2-(1-((((9H-Fluoren-9-yl)methoxy)carbonyl)amino)-2-(tert-butoxy)ethyl)oxazole-4carboxylic acid (S9)
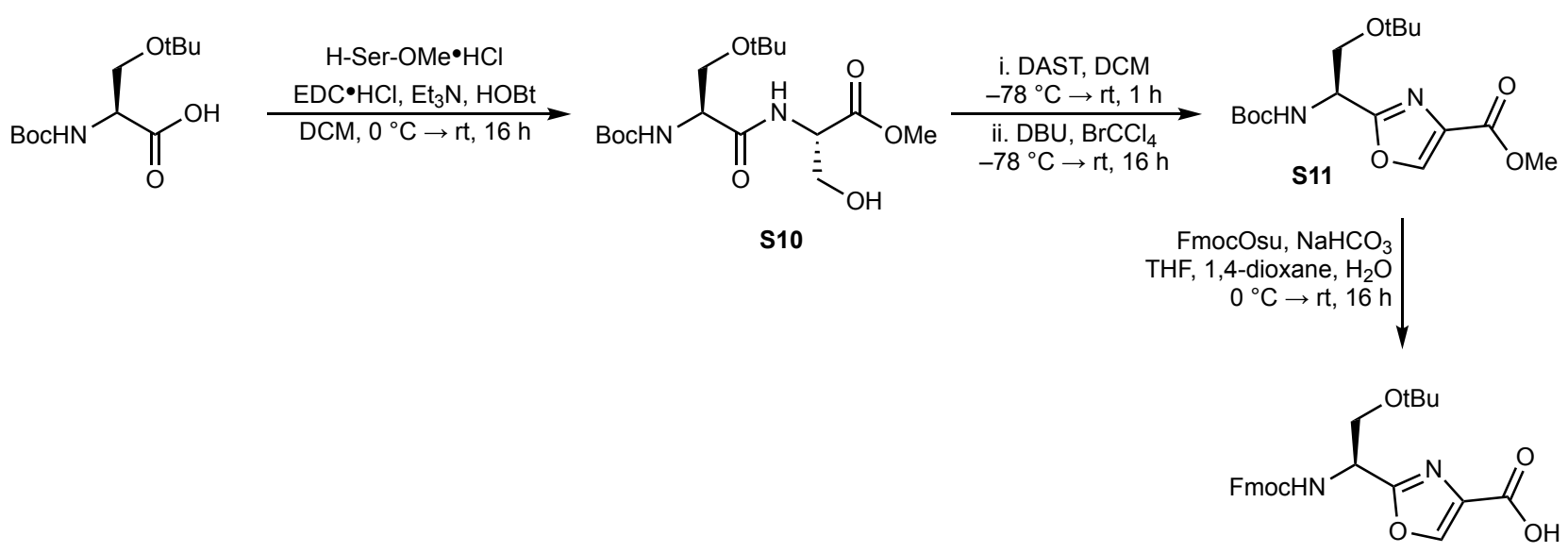
Methyl N-(tert-butoxycarbonyl)-O-(tert-butyl)-L-seryl-L-serinate (S10)<smiles>CCCCCC(NC(=O)[C@@H](CO)NC(=O)c1ccccc1)C(=O)OC</smiles>

In a 500-mL round bottom flask under $\mathrm{N}_{2}$ was dissolved Boc-Ser(tBu)-OH (2.00 g, $\left.7.65 \mathrm{mmol}\right), \mathrm{H}$ Ser-OMe $\cdot \mathrm{HCl}(1.19 \mathrm{~g}, 7.65 \mathrm{mmol})$, and HOBt $(1.20 \mathrm{~g}, 881 \mathrm{mmol})$ in DCM $(77 \mathrm{~mL}, 0.1 \mathrm{M})$ and the solution was cooled to $0{ }^{\circ} \mathrm{C}$. To the cooled solution was added $\mathrm{Et}_{3} \mathrm{~N}$ (3.2 mL, $23.0 \mathrm{mmol}$ ), dropwise, followed by $\mathrm{EDC} \cdot \mathrm{HCl}(1.48 \mathrm{~g}, 7.73 \mathrm{mmol})$. The solution was let warm to room temperature and stirred overnight. Upon consumption of the starting material by TLC, the reaction was concentrated in vacuo and the contents were dissolved in EtOAc $(100 \mathrm{~mL})$. The organics were washed with $0.5 \mathrm{M}$ citric acid $(1 \times 50 \mathrm{~mL})$ and brine $(1 \times 50 \mathrm{~mL})$, dried over $\mathrm{Na}_{2} \mathrm{SO}_{4}$, filtered, and concentrated in vacuo to provide the titled compound $(1.54 \mathrm{~g}, 4.25 \mathrm{mmol}, 56 \%$ yield) as a white solid, which was used without further purification.

${ }^{1} \mathrm{H}$ NMR $\left(400 \mathrm{MHz}, \mathrm{CDCl}_{3}\right) \delta 7.53(\mathrm{~d}, J=7.56 \mathrm{~Hz}, 1 \mathrm{H}), 5.48(\mathrm{~d}, J=6.20 \mathrm{~Hz}, 1 \mathrm{H}), 4.59(\mathrm{t}, J=3.34$ $\mathrm{Hz}, 1 \mathrm{H}), 4.17$ (br. s, 1H), 3.83-3.92 (m, 2H), 3.70 (s, 3H), 3.68-3.70 (m, 1H), 3.40 (t, J= $7.78 \mathrm{~Hz}$, $1 \mathrm{H}), 1.39(\mathrm{~s}, 9 \mathrm{H}), 1.13(\mathrm{~s}, 9 \mathrm{H})$

${ }^{13} \mathrm{C}$ NMR $\left(100 \mathrm{MHz}, \mathrm{CDCl}_{3}\right) \delta 171.07,170.63,155.64,80.18,74.09,62.81,61.95,54.88,54.42$, $28.30,27.31$

LCMS ESI: $\mathrm{C}_{16} \mathrm{H}_{30} \mathrm{~N}_{2} \mathrm{O}_{7}^{+}[\mathrm{M}+\mathrm{H}]^{+}$Exact Mass: 363.2126; Observed: 363.2144; $[\mathrm{M}+\mathrm{Na}]^{+}$Exact Mass: 385.1945; Observed 385.1965

\section{Methyl (S)-2-(2-(tert-butoxy)-1-((tert-butoxycarbonyl)amino)ethyl)oxazole-4-carboxylate} (S11)<smiles>CCCCCC(COCCCC)c1nc(C(=O)OC)co1</smiles>

In a $50-\mathrm{mL}$ round bottom flask under $\mathrm{N}_{2}$ was dissolved $\mathbf{S 1 0}(2.28 \mathrm{~g}, 6.29 \mathrm{mmol})$ in DCM $(27.4 \mathrm{~mL}$, $0.23 \mathrm{M})$ and the solution was cooled to $-78^{\circ} \mathrm{C}$. To the vessel was then slowly added DAST $(0.91$ $\mathrm{mL}, 6.92 \mathrm{mmol}$ ) and the reaction was slowly warmed to room temperature for 1 hour. Upon consumption of the starting material by TLC, the reaction was quenched via addition of $\sim 5 \mathrm{~mL}$ of saturated aqueous $\mathrm{NaHCO}_{3}$ and the organics were separated from the aqueous layer and dried 
with $\mathrm{Na}_{2} \mathrm{SO}_{4}$. The organic layer was filtered and concentrated in vacuo to provide the desired oxazoline intermediate as an orange oil. This intermediate was dissolved in DCM (27.4 mL, $0.23 \mathrm{M})$ and the solution was cooled to $-78^{\circ} \mathrm{C}$. After 15 minutes of cooling, DBU (3.46 mL, 23.0 $\mathrm{mmol}$ ) and bromotrichloromethane $(1.28 \mathrm{~mL}, 23.0 \mathrm{mmol})$ were added to the reaction and the solution was allowed to slowly warm to room temperature and stir overnight. Upon consumption of the intermediate by TLC, the reaction mixture was concentrated in vacuo and loaded directly onto a column. Purification by silica gel chromatography, eluting 0-50\% EtOAc/hexanes provided the titled compound $(1.30 \mathrm{~g}, 6.29 \mathrm{mmol}, 60 \%$ yield) as a white solid.

${ }^{1} \mathrm{H}$ NMR $\left(400 \mathrm{MHz}, \mathrm{CDCl}_{3}\right) \delta 8.16(\mathrm{~s}, 1 \mathrm{H}), 5.52(\mathrm{~d}, J=7.64 \mathrm{~Hz}, 1 \mathrm{H}), 5.00(\mathrm{t}, J=3.78,1 \mathrm{H}), 3.88$ (s, 3H), 3.63-3.81 (m, 2H), $1.42(\mathrm{~s}, 9 \mathrm{H}), 1.06(\mathrm{~s}, 9 \mathrm{H})$

${ }^{13} \mathrm{C}$ NMR $\left(100 \mathrm{MHz}, \mathrm{CDCl}_{3}\right) \delta 164.27,161.76,144.09,133.45,80.26,73.80,63.05,52.79$, $50.16,28.42,27.38$

LCMS ESI: $\mathrm{C}_{16} \mathrm{H}_{26} \mathrm{~N}_{2} \mathrm{O}_{6}{ }^{+}[\mathrm{M}+\mathrm{Na}]^{+}$Exact Mass: 365.1683; Observed 365.1687

(S)-2-(1-((((9H-Fluoren-9-yl)methoxy)carbonyl)amino)-2-(tert-butoxy)ethyl)oxazole-4carboxylic acid (S9)

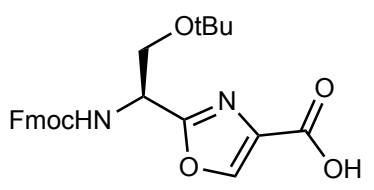

In a 100-mL round bottom flask was dissolved $\mathbf{S 1 1}(5.14 \mathrm{~g}, 15.0 \mathrm{mmol})$ in 1,4-dioxane (31 $\mathrm{mL}$, $0.5 \mathrm{M}$ ) and the solution was cooled to $0^{\circ} \mathrm{C}$. Once the solution was cooled, a $4 \mathrm{M}$ solution of $\mathrm{HCl}$ was added $(3.75 \mathrm{~mL})$ and the reaction was slowly let warm to room temperature and stir for 4 hours. Upon removal of the Boc group, indicated by TLC, the reaction was neutralized with a $1 \mathrm{M}$ $\mathrm{NaOH}$ solution and was concentrated in vacuo. The resulting solution was washed several times with DCM and the crude material was dissolved in THF (13 mL, 1.2 M), 1,4-dioxane (13 mL, 1.2 $\mathrm{M})$, and water $(13 \mathrm{~mL}, 1.2 \mathrm{M})$. Using solid $\mathrm{NaHCO}_{3}$, the $\mathrm{pH}$ of the solution was adjusted to $\sim 7.0$ 7.5, followed by the addition of Fmoc-OSu (5.31 g, $16.5 \mathrm{mmol})$, scoop-wise. The reaction was put under $\mathrm{N}_{2}$ and allowed to stir at room temperature overnight. Upon consumption of the intermediate by TLC, the solution was quenched with a $1 \mathrm{~N}$ solution of $\mathrm{HCl}$ to a $\mathrm{pH}$ of $\sim 3$. The solution was concentrated in vacuo to the aqueous layer and the resulting slurry was suspended in $10 \%$ EtOAc/hexanes $(75 \mathrm{~mL})$ and sonicated heavily. The suspension was filtered and the filtrate was discarded, providing the titled compound (5.60 g, 79\% yield) as an off-white solid. 
${ }^{1}$ H NMR (400 MHz, DMSO-d $\left.d_{6}\right) \delta 13.04$ (br. s, 1H), 8.71 (s, 1H), 8.06 (d, J = 8.36 Hz, 1H), 7.88 (d, $J=7.52 \mathrm{~Hz}, 2 \mathrm{H}), 7.72(\mathrm{~d}, J=7.36 \mathrm{~Hz}, 2 \mathrm{H}), 7.41(\mathrm{t}, J=7.36 \mathrm{~Hz}, 2 \mathrm{H}), 7.32(\mathrm{t}, J=7.78 \mathrm{~Hz}, 2 \mathrm{H})$, $4.80(\mathrm{q}, J=7.29 \mathrm{~Hz}, 1 \mathrm{H}), 4.20-4.35(\mathrm{~m}, 2 \mathrm{H}), 3.64-3.76(\mathrm{~m}, 2 \mathrm{H}), 1.09(\mathrm{~s}, 9 \mathrm{H})$

${ }^{13} \mathrm{C}$ NMR (100 MHz, DMSO- $\left.d_{6}\right) \delta 163.04,162.01,155.83,145.20,143.76,140.72,133.21$, $127.65,127.06,125.30,120.12,73.14,65.83,61.75,49.99,46.61,27.18$

LCMS ESI: $\mathrm{C}_{25} \mathrm{H}_{26} \mathrm{~N}_{2} \mathrm{O}_{6}{ }^{+}[\mathrm{M}+\mathrm{H}]^{+}$Exact Mass: 451.1864; Observed: 451.1858; $[\mathrm{M}+\mathrm{Na}]^{+}$Exact Mass: 473.1683; Observed 473.1678

(S)-2-(1-((((9H-fluoren-9-yl)methoxy)carbonyl)amino)-2-(tritylthio)ethyl-1,2- $\left.{ }^{13} C_{2}\right)$ thiazole-4carboxylic-2- ${ }^{13} \mathrm{C}$ acid (S12)

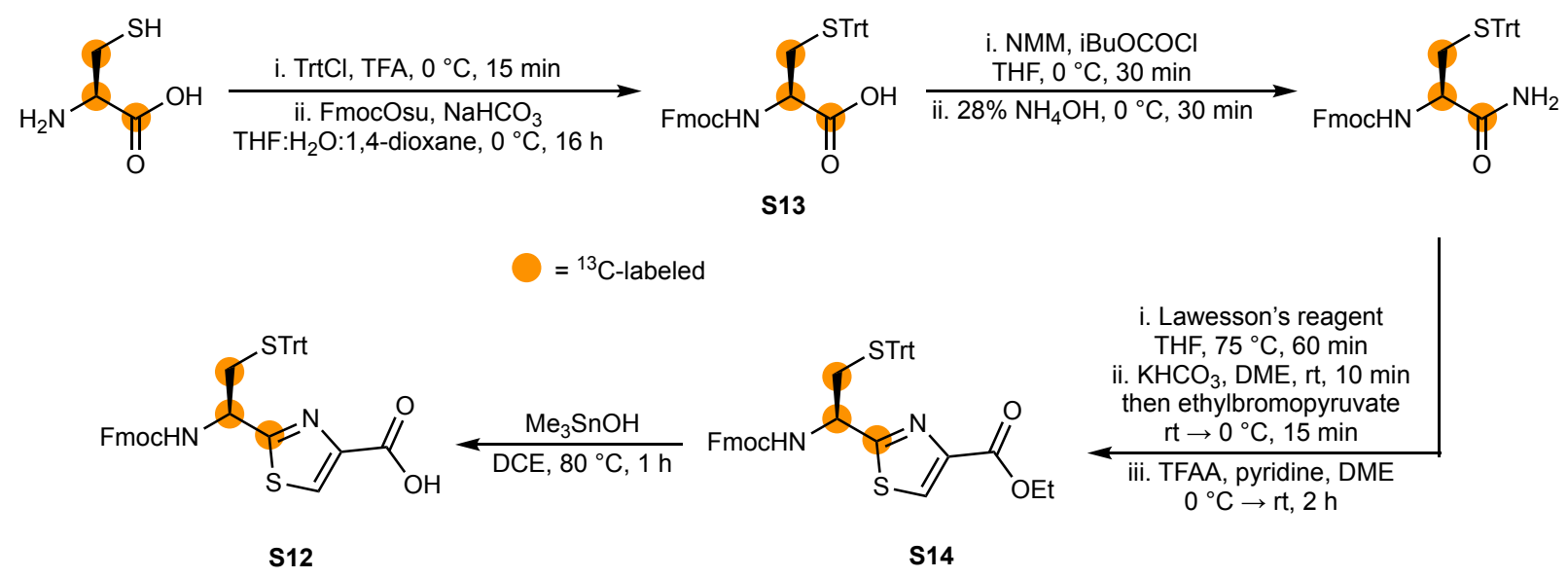

$N-\left(\left((9 H-F l u o r e n-9-y l)\right.\right.$ methoxy)carbonyl)-S-trityl-L-cysteine- ${ }^{13} C_{3}$ (S13)<smiles>O=C(O)C(CBr)NC(F)F</smiles>

In a $100-\mathrm{mL}$ round bottom flask was dissolved L-cysteine $-{ }^{13} C_{3}{ }^{3}(0.25 \mathrm{~g}, 2.01 \mathrm{mmol})$ and trityl chloride $(0.64 \mathrm{~g}, 2.22 \mathrm{mmol})$ in TFA $(20 \mathrm{~mL})$ at $0{ }^{\circ} \mathrm{C}$, which was added drop-wise. The reaction was allowed to stir for 15 minutes after which the reaction was assumed complete. The crude material was concentrated under reduced pressure to yield a crude oil, which was dissolved in a small amount of DCM (25 mL), transferred to a separatory funnel, and washed with water $(2 \times 15$ $\mathrm{mL}$ ). The organics were dried over $\mathrm{Na}_{2} \mathrm{SO}_{4}$, filtered, and concentrated in vacuo to provide a solid

${ }^{3}$ L-cysteine- ${ }^{13} C_{3}$ is commercially available through Cambridge Isotope Laboratories, Inc. 
which was used without further purification. In a 100-mL round bottom flask, this crude solid was dissolved in THF (12 mL), 1,4-dioxane $(12 \mathrm{~mL})$, and water $(12 \mathrm{~mL})$ and cooled to $0{ }^{\circ} \mathrm{C}$. To the cooled solution was then added $\mathrm{NaHCO}_{3}(0.42 \mathrm{~g}, 5.04 \mathrm{mmol})$ followed by FmocOSu $(0.75 \mathrm{~g}, 2.22$ $\mathrm{mmol}$ ) portion-wise and the reaction was let warm to room temperature and stirred overnight. Upon conversion of the intermediate by TLC, the reaction solution was concentrated in vacuo to the aqueous phase and acidified to a $\mathrm{pH}$ of 3 with a $1 \mathrm{~N} \mathrm{HCl}$ solution. The organics were extracted with EtOAc ( $2 \times 25 \mathrm{~mL})$, concentrated, and loaded directly onto a column. Purification via silica gel chromatography, eluting 0-100\% EtOAc/hexanes provided the titled compound (1.19 g, 2.02 mmol, $>95 \%$ yield) as a white solid.

${ }^{1} \mathrm{H}$ NMR $\left(400 \mathrm{MHz}, \mathrm{CDCl}_{3}\right) \delta \mathrm{ppm}$ 7.75-7.79 (m, 2H), 7.58-7.61 (m, 2H) 7.18-7.41 (m, $\left.19 \mathrm{H}\right), 5.15$ (d, J = 6.40 Hz, 1H), 4.40 (t, J=6.70 Hz, 2H), 4.22 (t, J=6.56 Hz, 1H), $2.90(\mathrm{~s}, 1 \mathrm{H}), 2.54(\mathrm{~s}, 1 \mathrm{H})$ ${ }^{13} \mathrm{C}$ NMR $\left(100 \mathrm{MHz}, \mathrm{CDCl}_{3}\right) \delta$ ppm $174.76(\mathrm{~d}, J=58.94 \mathrm{~Hz}), 156.07,144.29,143.89,143.77$, $141.43,129.64,128.23,128.07,127.91,127.13,120.13,67.45,67.39,52.92$ (dd, J = 85.84, 35.60 $\mathrm{Hz}), 47.22,33.56(\mathrm{~d}, J=35.52 \mathrm{~Hz})$

LCMS ESI: $\mathrm{C}_{16} \mathrm{H}_{30} \mathrm{~N}_{2} \mathrm{O}_{7}^{+}[\mathrm{M}+\mathrm{Na}]^{+}$Exact Mass: 611.1967; Observed 611.1974

\section{Ethyl (S)-2-(1-((((9H-fluoren-9-yl)methoxy)carbonyl)amino)-2-(tritylthio)ethyl-1,2-} $\left.{ }^{13} C_{2}\right)$ thiazole-4-carboxylate-2- ${ }^{13} C(\mathrm{~S} 14)$

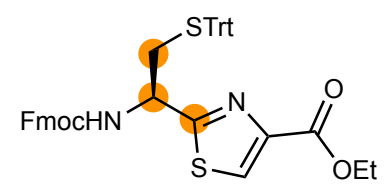

This procedure was carried out analogously to the synthesis of the unlabeled compound S6. ${ }^{1}$ In a $100-\mathrm{mL}$ round bottom flask under $\mathrm{N}_{2}$ was dissolved $\mathbf{S 1 3}(1.19 \mathrm{~g}, 2.02 \mathrm{mmol})$ in THF (10 mL, $0.2 \mathrm{M})$ and the solution was cooled to $0^{\circ} \mathrm{C}$. Next was added $\mathrm{N}$-methylmorpholine $(0.25 \mathrm{~mL}, 2.22$ $\mathrm{mmol})$ and subsequently isobutyl chloroformate $(0.30 \mathrm{~mL}, 2.22 \mathrm{mmol})$ drop-wise and the temperature of the solution was slowly raised to $23^{\circ} \mathrm{C}$ over a period of 30 minutes. The solution was then cooled back down to $0{ }^{\circ} \mathrm{C}$ and ammonium hydroxide ${ }^{4}(1.4 \mathrm{~mL}, 10.1 \mathrm{mmol})$ was added drop-wise to the solution and the reaction was stirred at $0{ }^{\circ} \mathrm{C}$ and monitored by TLC. Complete consumption of the intermediate was observed in 30-45 minutes and the reaction was warmed to room temperature, concentrated in vacuo, and diluted with EtOAc $(50 \mathrm{~mL})$. The organics were washed with a $0.5 \mathrm{M}$ aqueous citric acid solution $(1 \times 25 \mathrm{~mL})$ and brine $(1 \times 25 \mathrm{~mL})$, dried over

\footnotetext{
${ }^{4}$ Added as a $28 \%$ aqueous solution.
} 
$\mathrm{Na}_{2} \mathrm{SO}_{4}$, filtered, and concentrated in vacuo to provide the carboxamide intermediate $(1.19 \mathrm{~g}, 2.02$ mmol, $>95 \%$ yield) as a crude white solid, which was used in the next step without further purification.

In a 100-mL round bottom flask under $\mathrm{N}_{2}$ was dissolved the crude carboxamide intermediate (1.19 $\mathrm{g}, 2.02 \mathrm{mmol})$ in THF (10 mL, 0.2M) followed by the addition of Lawesson's reagent $(0.61 \mathrm{~g}, 1.52$ $\mathrm{mmol}$ ) and the reaction was refluxed at $75^{\circ} \mathrm{C}$ for 1 hour. Upon consumption of the intermediate by TLC, the reaction was concentrated in vacuo and the material was pushed through a silica plug, washed with hexanes, eluted with EtOAc and used without further purification.

The white solid was dissolved in DME $(2.8 \mathrm{~mL}, 0.67 \mathrm{M})$ in a round bottom flask under $\mathrm{N}_{2}$ after which potassium bicarbonate $(1.51 \mathrm{~g}, 15.0 \mathrm{mmol})$ was added to the flask and stirred for 10 minutes at room temperature. To the flask was then added ethyl 3-bromo-2-oxopropanoate (0.79 $\mathrm{mL}, 5.66 \mathrm{mmol}$ ) and the reaction was stirred for 30 minutes at room temperature and cooled to 0 ${ }^{\circ} \mathrm{C}$. A solution of TFAA $(1.06 \mathrm{~mL}, 7.51 \mathrm{mmol})$ and pyridine $(1.30 \mathrm{~mL}, 16.0 \mathrm{mmol})$ in DME $(2.0 \mathrm{~mL}$, $0.94 \mathrm{M}$ ) at $0{ }^{\circ} \mathrm{C}$ was added dropwise to the reaction, which was slowly warmed to room temperature and stirred overnight. Another $2 \mathrm{~mL}$ of TFAA was added to the reaction after TLC indicated incomplete conversion from the intermediate to the product. Upon consumption of the remaining intermediate by TLC ( 30 mins), the reaction was concentrated in vacuo and dissolved in EtOAc (100 mL). The organics were washed vigorously with water until effervescence had ceased and then separated from the aqueous. The aqueous layer was back extracted with DCM $(2 \times 50 \mathrm{~mL})$ and the combined organics were dried over $\mathrm{Na}_{2} \mathrm{SO}_{4}$, filtered, concentrated, and loaded directly onto a column. Purification via silica gel chromatography, eluting $0-35 \%$ EtOAc/hexanes provided the titled compound $(1.09 \mathrm{~g}, 1.56 \mathrm{mmol}, 83 \%$ yield) as a light orange solid.

${ }^{1}$ H NMR (400 MHz, $\left.\mathrm{CDCl}_{3}\right) \delta$ ppm $8.02(\mathrm{~d}, J=7.36 \mathrm{~Hz}, 1 \mathrm{H}), 7.73(\mathrm{~d}, J=8.16 \mathrm{~Hz}, 2 \mathrm{H}), 7.57$ (s, 2H), 7.20-7.46 (m, 19H), $5.21(\mathrm{~d}, J=5.16 \mathrm{~Hz}, 1 \mathrm{H}), 4.38-4.45(\mathrm{~m}, 4 \mathrm{H}), 4.19(\mathrm{t}, J=5.94 \mathrm{~Hz}, 1 \mathrm{H})$, $3.06(\mathrm{~s}, 1 \mathrm{H}), 2.69(\mathrm{~s}, 1 \mathrm{H}), 1.37-1.42(\mathrm{~m}, 3 \mathrm{H})$

${ }^{13} \mathrm{C}$ NMR (100 MHz, $\mathrm{CDCl}_{3}$ ) $\delta \mathrm{ppm} 172.52$ (d, $\left.J=57.21\right), 161.22,155.79,147.26,144.29,143.69$, 141.46, 129.81, 129.63, 128.27, 127.88, 127.22, 127.15, 125.15, 120.14, 67.81, 67.11, 61.86, 52.26 (dd, $J=57.30,36.33 \mathrm{~Hz}$ ), 47.26, $36.52(\mathrm{~d}, J=36.23 \mathrm{~Hz}) 14.40$

LCMS ESI: $\mathrm{C}_{39}{ }^{13} \mathrm{C}_{3} \mathrm{H}_{36} \mathrm{~N}_{2} \mathrm{NaO}_{4} \mathrm{~S}_{2}{ }^{+}[\mathrm{M}+\mathrm{Na}]^{+}$Exact Mass: 722.2109; Observed 722.2111 
(S)-2-(1-((((9H-fluoren-9-yl)methoxy)carbonyl)amino)-2-(tritylthio)ethyl-1,2- $\left.{ }^{13} C_{2}\right)$ thiazole-4carboxylic-2- ${ }^{13} \mathrm{C}$ acid (S12)<smiles>O=C(O)c1csc(C(=O)CBr)n1</smiles>

In a $50-\mathrm{mL}$ round bottom flask was dissolved $\mathbf{S 1 3}(1.09 \mathrm{~g}, 1.56 \mathrm{mmol})$ in DCE $(15.6 \mathrm{~mL}$, $0.1 \mathrm{M})$ followed by the addition of trimethyltin hydroxide $(2.82 \mathrm{~g}, 15.6 \mathrm{mmol})$. The reaction was heated to $80^{\circ} \mathrm{C}$ and stirred for 1 hour and monitored by TLC. Upon consumption of the starting material by TLC, the reaction was concentrated in vacuo and loaded directly onto a column. Purification via silica gel chromatography, eluting $0-10 \% \mathrm{MeOH} / \mathrm{DCM}$ to provide the titled compound ( $0.43 \mathrm{~g}, 0.64 \mathrm{mmol}, 41 \%$ yield) as a light yellow solid.

${ }^{1}$ H NMR (400 MHz, $\left.\mathrm{CDCl}_{3}\right) \delta$ ppm $8.15(\mathrm{~d}, J=6.96 \mathrm{~Hz}, 1 \mathrm{H}), 7.75(\mathrm{t}, J=7.08 \mathrm{~Hz}, 2 \mathrm{H}), 7.57$ (s, 2H), 7.19-7.39 (19H), 5.25 (d, J=5.00 Hz, 1H), $4.98(\mathrm{~s}, 1 \mathrm{H}), 4.39-4.51(\mathrm{~m}, 2 \mathrm{H}), 4.19(\mathrm{~s}, 1 \mathrm{H}), 3.06$ (d, $J=2.94-3.10(\mathrm{~m}, 1 \mathrm{H}), 2.62-2.74(\mathrm{~m}, 1 \mathrm{H})$

${ }^{13} \mathrm{C}$ NMR $\left(100 \mathrm{MHz}, \mathrm{CDCl}_{3}\right) \delta \mathrm{ppm} 172.55(\mathrm{~d}, J=57.27 \mathrm{~Hz}), 162.13,155.64,144.30,143.69$, $141.44,129.82$, 129.65, 128.29, 128.07, 127.91, 127.86, 127.41, 127.23, 127.18, 120.16, 67.86, 66.98, 52.40 (dd, $J=57.16,35.57 \mathrm{~Hz}), 47.32,36.47$ (d, $J=36.28 \mathrm{~Hz}$ )

LCMS ESI: $\mathrm{C}_{37}{ }^{13} \mathrm{C}_{3} \mathrm{H}_{32} \mathrm{~N}_{2} \mathrm{NaO}_{4} \mathrm{~S}_{2}{ }^{+}[\mathrm{M}+\mathrm{Na}]^{+}$Exact Mass: 694.1796; Observed 694.1798

(S)-2'-(1-((((9H-fluoren-9-yl)methoxy)carbonyl)amino)-2-methylpropyl)-[2,4'-bioxazole]-4carboxylic $-{ }^{13} \mathrm{C}$ acid (S15)

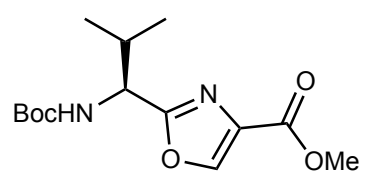

S8



$={ }^{13} \mathrm{C}$-labeled

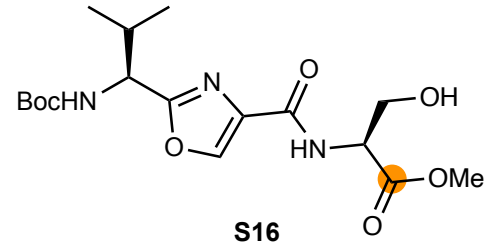

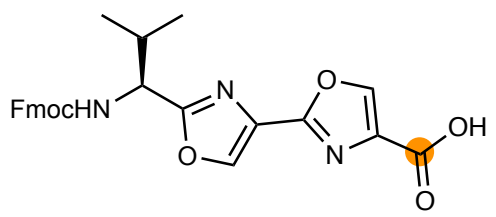

S15

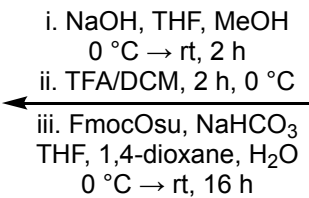

$0{ }^{\circ} \mathrm{C} \rightarrow \mathrm{rt}, 16 \mathrm{~h}$

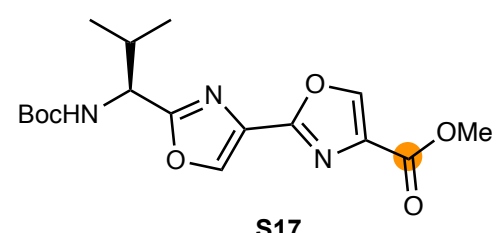

S17 


\section{Methyl (2-((S)-1-((tert-butoxycarbonyl)amino)-2-methylpropyl)oxazole-4-carbonyl)-L- serinate $-1-{ }^{13} C(\mathrm{~S} 16)$}



In a 250-mL round bottom flask was dissolved S8 $(2.69 \mathrm{~g}, 9.02 \mathrm{mmol})$ in THF (13.7 mL, 0.66M) and $\mathrm{MeOH}(13.7 \mathrm{~mL}, 0.66 \mathrm{M})$, cooled to $0^{\circ} \mathrm{C}$, and put under $\mathrm{N}_{2} . \mathrm{NaOH}$ (10M in water) $(2.7 \mathrm{~mL}$, $27.0 \mathrm{mmol}$ ) was added slowly, drop-wise over several minutes, after which the reaction was slowly warmed to room temperature. Upon consumption of the starting material by TLC, the reaction was concentrated in vacuo to the aqueous phase and acidified to a $\mathrm{pH}$ of 3 with $1 \mathrm{~N} \mathrm{HCl}$. The solution was then diluted with EtOAc $(70 \mathrm{~mL})$ and washed with brine $(1 \times 50 \mathrm{~mL})$. The organic layer was dried over $\mathrm{Na}_{2} \mathrm{SO}_{4}$, filtered, and concentrated provide a crude white intermediate. In a $100-\mathrm{mL}$ round bottom flask was dissolved the intermediate in DCM (18.1 mL, 0.1M). The solution was cooled to $0{ }^{\circ} \mathrm{C}$ and $\operatorname{EDC}(0.35 \mathrm{~g}, 1.83 \mathrm{mmol})$ and triethylamine $(0.75 \mathrm{~mL}, 5.42 \mathrm{mmol})$ were subsequently added. The reaction was slowly warmed to room temperature and let stir overnight. Upon consumption of the starting material by TLC, the reaction was concentrated in vacuo and the crude material was re-dissolved in EtOAc $(25 \mathrm{~mL})$. The organics were washed with water (2 $\times 25 \mathrm{~mL})$ and brine $(1 \times 25 \mathrm{~mL})$, dried over $\mathrm{Na}_{2} \mathrm{SO}_{4}$, filtered, and concentrated in vacuo to provide the titled compound $(0.410 \mathrm{~g}, 1.06 \mathrm{mmol}, 59 \%$ yield) as a white solid. The material was taken to the next step without further purification.

${ }^{1} \mathrm{H}$ NMR $\left(400 \mathrm{MHz}\right.$, DMSO- $\left.d_{6}\right) \delta 8.59(\mathrm{~s}, 1 \mathrm{H}), 7.95(\mathrm{~d}, J=8.0 \mathrm{~Hz}, 1 \mathrm{H}), 7.54(\mathrm{~d}, J=8.5 \mathrm{~Hz}, 1 \mathrm{H})$, 4.51 (ddt, $J=8.1,6.8,4.1 \mathrm{~Hz}, 1 \mathrm{H}), 4.43(\mathrm{t}, J=8.2 \mathrm{~Hz}, 1 \mathrm{H}$ ), 3.82 (ddd, $J=11.2,4.5,2.1 \mathrm{~Hz}, 1 \mathrm{H}$ ), 3.71 (ddd, $J=11.3,5.9,3.8 \mathrm{~Hz}, 1 \mathrm{H}), 3.62(\mathrm{~d}, J=3.8 \mathrm{~Hz}, 3 \mathrm{H}), 2.11(\mathrm{~h}, J=6.9 \mathrm{~Hz}, 1 \mathrm{H}), 1.34$ (s, $9 \mathrm{H}), 0.90(\mathrm{~d}, J=6.7 \mathrm{~Hz}, 3 \mathrm{H}), 0.76(\mathrm{~d}, J=6.7 \mathrm{~Hz}, 3 \mathrm{H})$.

${ }^{13} \mathrm{C}$ NMR (100 MHz, DMSO- $\left.d_{6}\right) \delta 171.39,171.09,170.78,170.72,169.24,164.59,160.26$, 155.88, 142.52, 135.52, 117.23, 114.35, 78.82, 61.50, 55.07, 54.96, 54.35, 52.52, 52.49, 31.49, 28.56, 28.27, 19.43, 19.15 .

LCMS ESI: $\mathrm{C}_{16}{ }^{13} \mathrm{CH}_{27} \mathrm{~N}_{3} \mathrm{NaO}_{7}{ }^{+}[\mathrm{M}+\mathrm{Na}]^{+}$Exact Mass: 409.1775 ; Observed: 409.1764 


\section{Methyl (S)-2'-(1-((tert-butoxycarbonyl)amino)-2-methylpropyl)-[2,4'-bioxazole]-4- carboxylate- ${ }^{13} \mathrm{C}(\mathrm{S} 17)$}<smiles>COC(=O)c1coc(-c2coc([C@@H](NC(C)(C)C)C(C)C)n2)n1</smiles>

In a 50-mL round bottom flask under $\mathrm{N}_{2}$ was dissolved $\mathbf{S 1 6}(0.41 \mathrm{~g}, 1.06 \mathrm{mmol})$ in DCM $(4.6 \mathrm{~mL}$, $0.23 \mathrm{M})$ and the solution was cooled to $-78^{\circ} \mathrm{C}$. To the vessel was then slowly added DAST $(0.15$ $\mathrm{mL}, 1.17 \mathrm{mmol}$ ) and the temperature was slowly warmed to room temperature for 1 hour. Upon consumption of the starting material by TLC, the reaction was quenched via addition of $\sim 5 \mathrm{~mL}$ of saturated aqueous $\mathrm{NaHCO}_{3}$ and the organics were separated from the aqueous layer and dried with $\mathrm{Na}_{2} \mathrm{SO}_{4}$. The organic layer was filtered and concentrated in vacuo to provide the desired oxazoline intermediate as an orange oil. The intermediate was re-dissolved in DCM (4.6 mL, $0.23 \mathrm{M})$ and the solution was cooled to $-78^{\circ} \mathrm{C}$. After 15 minutes of cooling, DBU $(0.72 \mathrm{~mL}, 4.77$ $\mathrm{mmol})$ and bromotrichloromethane $(0.31 \mathrm{~mL}, 3.18 \mathrm{mmol})$ were added to the reaction and the solution was allowed to slowly warm to room temperature and stirred overnight. Upon consumption of the intermediate by TLC, the reaction mixture was concentrated in vacuo and loaded directly onto a column. Purification by silica gel chromatography, eluting $0-50 \%$ EtOAc/hexanes provided the titled compound $(0.23 \mathrm{~g}, 0.63 \mathrm{mmol}, 59 \%$ yield $)$ as a white solid.

${ }^{1}$ H NMR (400 MHz, DMSO- $\left.d_{6}\right) \delta 8.91(\mathrm{~s}, 1 \mathrm{H}), 8.88(\mathrm{~s}, 1 \mathrm{H}), 7.57(\mathrm{~d}, J=8.5 \mathrm{~Hz}, 1 \mathrm{H}), 4.48(\mathrm{t}, J=$ $8.1 \mathrm{~Hz}, 1 \mathrm{H}), 3.80(\mathrm{~d}, J=3.9 \mathrm{~Hz}, 3 \mathrm{H}), 2.13(\mathrm{dq}, J=13.9,6.9 \mathrm{~Hz}, 1 \mathrm{H}), 1.35(\mathrm{~s}, 9 \mathrm{H}), 0.90$ (d, J = 6.7 $\mathrm{Hz}, 3 \mathrm{H}), 0.78(\mathrm{~d}, J=6.7 \mathrm{~Hz}, 3 \mathrm{H})$.

${ }^{13} \mathrm{C}$ NMR $\left(100 \mathrm{MHz}\right.$, DMSO- $\left.d_{6}\right) \delta 170.96,165.78,161.80,161.32,160.85,159.41,155.92$, 155.69, 155.62, 145.95, 145.84, 141.16, 134.07, 133.12, 129.15, 78.81, 54.95, 52.36, 52.34, $31.44,28.58,19.40,19.08$.

LCMS ESI: $\mathrm{C}_{16}{ }^{13} \mathrm{CH}_{23} \mathrm{~N}_{3} \mathrm{NaO}_{6}{ }^{+}[\mathrm{M}+\mathrm{Na}]^{+}$Exact Mass: 389.1513 ; Observed: 389.1510 
(S)-2'-(1-((((9H-Fluoren-9-yl)methoxy)carbonyl)amino)-2-methylpropyl)-[2,4'-bioxazole]-4carboxylic $-{ }^{13} C$ acid (S15)

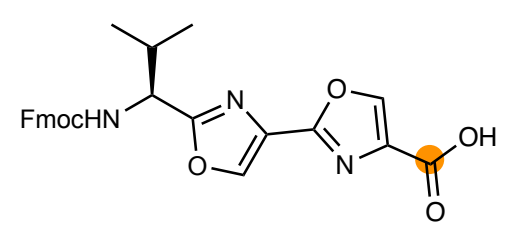

In a $100-\mathrm{mL}$ round bottom flask was dissolved $\mathbf{S} 17(0.23 \mathrm{~g}, 0.63 \mathrm{mmol})$ in THF $(1.57 \mathrm{~mL}$, $0.4 \mathrm{M})$ and $\mathrm{MeOH}(1.57 \mathrm{~mL}, 0.4 \mathrm{M})$ and the solution was cooled to $0{ }^{\circ} \mathrm{C}$. Once cooled, $\mathrm{NaOH}(1 \mathrm{M}$ in water) (2.51 $\mathrm{mL}, 2.51 \mathrm{mmol}$ ) was added dropwise and the reaction was allowed to warm to room temperature. Upon consumption of the starting material by TLC, the $\mathrm{pH}$ of the solution was adjusted to 3 using an aqueous $1 \mathrm{~N} \mathrm{HCl}$ solution. The solution was then concentrated to the aqueous phase and diluted with EtOAc $(50 \mathrm{~mL})$. The organics were washed with brine $(1 \times 50$ $\mathrm{mL}$ ), dried over $\mathrm{Na}_{2} \mathrm{SO}_{4}$, filtered, and concentrated in vacuo to provide a crude solid.

In a 100-mL round bottom flask, the crude solid was dissolved (suspended) in DCM (1.57 mL, $0.4 \mathrm{M})$ and cooled to $0{ }^{\circ} \mathrm{C}$, after which TFA $(1.57 \mathrm{~mL}, 0.4 \mathrm{M})$ was slowly added, drop-wise. The solution was allowed to warm to room temperature and stir for 2 hours. The reaction was concentrated in vacuo and washed several times with DCM to provide a crude light yellow oil.

In a 100-mL round bottom flask was dissolved the crude oil in THF (1.57 mL, 0.4M), water (1.57 $\mathrm{mL}, 0.4 \mathrm{M})$, and 1,4 -dioxane $(1.57 \mathrm{~mL}, 0.4 \mathrm{M})$ and the solution was cooled to $0{ }^{\circ} \mathrm{C}$. Once the solution was cooled, both sodium bicarbonate $(0.13 \mathrm{~g}, 1.57 \mathrm{mmol})$ and subsequently FmocOSu $(0.22 \mathrm{~g}, 0.69 \mathrm{mmol})$ were added scoop-wise. The reaction was allowed to slowly warm to room temperature and stir overnight. Upon consumption of the intermediate by TLC, the $\mathrm{pH}$ of the reaction was adjusted to $\sim 3$ using an aqueous $1 \mathrm{~N} \mathrm{HCl}$ solution. The reaction was concentrated in vacuo to provide a crude white solid, which was loaded directly onto a column. Purification via silica gel chromatography, eluting $0-10 \% \mathrm{MeOH} / \mathrm{DCM}$ provided the titled compound $(0.18 \mathrm{~g}, 0.38$ $\mathrm{mmol}, 60 \%$ yield) as a white solid.

${ }^{1} \mathrm{H}$ NMR $\left(400 \mathrm{MHz}\right.$, DMSO- $\left.d_{6}\right) \delta 8.87(\mathrm{~s}, 1 \mathrm{H}), 8.81(\mathrm{~s}, 1 \mathrm{H}), 8.14(\mathrm{~d}, J=8.5 \mathrm{~Hz}, 1 \mathrm{H}), 7.86(\mathrm{dd}, J=$ 13.9, 7.5 Hz, 2H), $7.73-7.62(\mathrm{~m}, 2 \mathrm{H}), 7.42-7.23(\mathrm{~m}, 4 \mathrm{H}), 4.54(\mathrm{t}, J=8.2 \mathrm{~Hz}, 1 \mathrm{H}), 4.36-4.15$ (m, 3H), $2.20(\mathrm{dq}, J=13.6,6.7 \mathrm{~Hz}, 1 \mathrm{H}), 0.94(\mathrm{~d}, J=6.7 \mathrm{~Hz}, 3 \mathrm{H}), 0.81(\mathrm{~d}, J=6.8 \mathrm{~Hz}, 3 \mathrm{H})$.

${ }^{13} \mathrm{C}$ NMR $\left(100 \mathrm{MHz}\right.$, DMSO- $\left.d_{6}\right) \delta 165.49,162.23,144.18,141.14,141.05,128.06,127.48$, $125.71,120.53,66.20,55.48,47.09,31.41,19.44,19.11$. 
LCMS ESI: $\mathrm{C}_{26} \mathrm{H}_{24} \mathrm{~N}_{3} \mathrm{O}_{6}{ }^{+}[\mathrm{M}+\mathrm{Na}]^{+}$Exact Mass: 474.1660; Observed: 474.1662

\section{Solid Phase Peptide Synthesis (SPPS)}

All unlabeled peptides were synthesized following the "general room temperature SPPS method" with Rink Amide ChemMatrix ${ }^{\circledR}$ resin. ${ }^{5}$ These peptides were cleaved and purified following the "general peptide cleavage method."

\section{General Room Temperature SPPS Method:}

Resin (20-100 mg) was initially swollen in DMF (1.5-6.0 mLs) for $30 \mathrm{~min}$ at room temperature.

(i) Coupling: Fmoc-AA-OH (5.0 equiv., $0.5 \mathrm{M}$ in DMF), HATU (5.0 equiv., $0.5 \mathrm{M}$ in DMF), and DIPEA (10.0 equiv., 1.0 M in DMF) were added to the swollen resin in that order. The resulting suspension was stirred for 15 minutes at room temperature. The reaction vessel is then drained and the resin is thoroughly washed with DMF $(4 \times 5 \mathrm{~mL})$.

(ii) Fmoc Deprotection: Following coupling and washing, excess $20 \%$ piperidine (in DMF) is added to the reaction vessel and allowed to incubate for 10 minutes while stirring at room temperature. The reaction vessel is drained and the resin is thoroughly washed with DMF (4 $55 \mathrm{~mL})$.

\section{General Peptide Cleavage Method:}

The resin was washed several times with DMF and DCM and then dried and cleaved using a cleavage cocktail (TFA/TIPS/ $\left.\mathrm{H}_{2} \mathrm{O}, 95: 2.5: 2.5\right)$ at $37^{\circ} \mathrm{C}$ for $1 \mathrm{~h}$. The resin was then filtered from the cleavage cocktail solution and dried under a stream of nitrogen. Cooled $\mathrm{Et}_{2} \mathrm{O}$ (at least 10 times the volume of the residual TFA) was added to crash out the crude peptide. The crude peptide was pelleted by centrifugation ( $10 \mathrm{~min}$ at $15,000 \mathrm{rpm}$ at $4^{\circ} \mathrm{C}$ ) and then decanted. The crude peptide was dissolved in DMF, diluted with $\mathrm{MeCN}: \mathrm{H}_{2} \mathrm{O}(1: 1)$ and purified by reverse-phase preparatory HPLC using method A or B (page S2). Fractions containing the peptide of interest were analyzed by LCMS to verify their identities and lyophilized.

\section{Conversion of Cysteines to Dehydroalanines}

The cysteine-containing peptide substrates were dissolved to a final concentration of $0.63 \mathrm{mM}$ in a solution of DMF: $\mathrm{H}_{2} \mathrm{O}(1: 1)$ and reduced with TCEP (2.0 equiv.) for 15 minutes at room temperature. The crude material was then cooled to $0{ }^{\circ} \mathrm{C}$ and $\mathrm{K}_{2} \mathrm{CO}_{3}$ (100.0 equiv.) was added scoop-wise followed by dropwise addition of methyl 2,5-dibromovalerate (100.0 equiv.) The

\footnotetext{
${ }^{5}$ Slightly different parameters were used in the synthesis of ${ }^{13} \mathrm{C}$-labeled intermediate 6 '. See section 9 . Synthesis and Isolation of ${ }^{13} \mathrm{C}$-Labeled Intermediate (6') and Thiopeptide (7') for details.
} 
reaction was allowed to stir at $37^{\circ} \mathrm{C}$ for 3 hours after which the crude peptide was diluted in MeCN: $\mathrm{H}_{2} \mathrm{O}(1: 1)$ and purified by reverse-phase preparatory HPLC using method A or $B$ (page S2). Fractions containing peptide of interest were analyzed by LCMS to verify their identities and lyophilized.

\section{Protein Expression and Purification}

The purification of TbtD has been previously described. ${ }^{23}$ TbtD was heterologously expressed in E. coli BL21 (DE3) cells and purified separately as follows. $1 \mathrm{~L}$ of Luria-Bertani (LB) medium, supplemented with ampicillin $(100 \mu \mathrm{g} / \mathrm{mL})$ was inoculated with $5 \mathrm{~mL}$ of an overnight seed and grown to an $\mathrm{OD}_{600}$ between $0.6-0.8$ at $37^{\circ} \mathrm{C}$, at which point $400 \mu \mathrm{L}$ of a $1 \mathrm{M}$ stock of IPTG was added and culture grown for $18 \mathrm{~h}$ at $16^{\circ} \mathrm{C}$. Cells were pelleted and resuspended in $40 \mathrm{~mL}$ of lysis/binding buffer $\left(50 \mathrm{mM} \mathrm{KHPO}_{4}\right.$ at $\mathrm{pH}=7.00,250 \mathrm{mM} \mathrm{KCl}, 10 \mathrm{mM}$ imidazole, and 10\% glycerol) supplemented with $250 \mu \mathrm{g} / \mathrm{mL}$ lysozyme, $2 \mathrm{mM} \mathrm{PMSF}$, and 1-protease inhibitor tablet (ROCHE). Cells were lysed by sonicating twice with a $20 \%$ maximum amplitude intermittent pulses for 1:30 min. Cell debris was removed by centrifugation (20 min at $15,000 \mathrm{rpm}$ at $4^{\circ} \mathrm{C}$ ) and supernatant collected and cold filtered through a $0.44 \mu \mathrm{m}$ filter. Supernatant was loaded into a 5$\mathrm{mL}$ HisTrap $\left(\mathrm{Ni}^{2+}\right)$ IMAC column and washed $(5 \mathrm{CV})$ to remove non-specific binding. 6xHis-MBPTbtD was eluted with an elution buffer gradient $\left(50 \mathrm{mM} \mathrm{KHPO}_{4}\right.$ at $\mathrm{pH}=7.00,250 \mathrm{mM} \mathrm{KCl}, 500$ $\mathrm{mM}$ imidazole, and 10\% glycerol) from $0-100 \%$ (6 CV). Fractions containing eluted protein were pooled and concentrated to $5 \mathrm{~mL}$ or less utilizing a Centricon (30,000 Da MWCO) concentrator (EMD Millipore). The resulting concentrated protein was buffer-exchanged into $50 \mathrm{mM} \mathrm{KHPO}_{4}$ at $\mathrm{pH}=7.00,250 \mathrm{mM} \mathrm{KCl}$, and 10\% glycerol utilizing a PD-10 column (GE Healthcare Life Sciences). The concentration of each 6 xHis-MBP-enzyme was determined by UV absorbance at 280nm. Enzymes were used for all assay directly from the PD-10 elution. 


\section{General Information for Intramolecular Cyclization Assays with TbtD}

Initial Test Cyclization Assay: Cyclization assays were performed using $20 \mu \mathrm{M}$ substrate and 10 $\mu \mathrm{M}$ MBP-TbtD in a total volume of $50 \mu \mathrm{L}$ using the buffers listed below. Reactions were incubated at $25^{\circ} \mathrm{C}$ on the bench top for 21 hours. After 21 hours, $100 \mu \mathrm{L}$ of methanol was added to each reaction to crash out MBP-TbtD. Insoluble material was then removed by centrifugation (15,000 rpm, $5 \mathrm{~min}, 25^{\circ} \mathrm{C}$ ) and the samples were analyzed LCMS using method $\mathrm{B}$.

Time Course Cyclization Assays: Cyclization assays were performed using $200 \mu \mathrm{M}$ substrate and $50 \mu \mathrm{M}$ MBP-TbtD in a total volume of $110 \mu \mathrm{L}$ using the buffers listed below. Reactions were incubated at $25^{\circ} \mathrm{C}$ on the bench top. Individual time points were taken at $0,2.5,5,10,15,30,60$, $90,120,180,240$ and 360 minutes by taking a $10 \mu \mathrm{L}$ aliquot and adding it to $90 \mu \mathrm{L}$ of $\mathrm{MeOH}$. Insoluble material was then removed by centrifugation $\left(15,000 \mathrm{rpm}, 5 \mathrm{~min}, 25^{\circ} \mathrm{C}\right)$ and the samples were analyzed analytical HPLC using method A.

Buffers Used:

pH 7.2 Buffer: 50 mM HEPES, $150 \mathrm{mM} \mathrm{NaCl}$, pH 7.2 pH 8.0 Buffer: 50 mM HEPES, $150 \mathrm{mM} \mathrm{NaCl}$, pH 8.0 pH 8.5 Buffer: $50 \mathrm{mM}$ HEPES, $150 \mathrm{mM} \mathrm{NaCl}$, pH 8.5 pH 9.0 Buffer: $50 \mathrm{mM}$ CHES, $150 \mathrm{mM} \mathrm{NaCl}$, pH 9.0 pH 9.5 Buffer: $50 \mathrm{mM}$ CHES, $150 \mathrm{mM} \mathrm{NaCl}$, pH 9.5 pH 10.0 Buffer: $50 \mathrm{mM}$ CHES, $150 \mathrm{mM} \mathrm{NaCl}, \mathrm{pH} 10.0$ pH 10.5 Buffer: 50 mM CAPS, $150 \mathrm{mM} \mathrm{NaCl}$, pH 10.5 


\section{Table S1 - Summary of Cyclizations with Variant Substrates}

\begin{tabular}{|c|c|c|c|c|}
\hline \multicolumn{2}{|c|}{ Linear Substrate Compound Number \& Sequence } & \multirow{2}{*}{$\frac{\text { Intermediate Observed }}{\text { no }}$} & \multirow{2}{*}{$\begin{array}{c}\text { Thiopeptide Observed } \\
\text { yes }(\mathrm{s} 18)\end{array}$} & \multirow{2}{*}{$\begin{array}{r}\text { AlogP } \\
4.22\end{array}$} \\
\hline $\mathbf{s 2 5}$ & LP-DhaThzAsn(NMe) ThzPheThzTyrValThzThzDhaOxz & & & \\
\hline 4 & LP-DhaThzAsn (NMe) ThzPheThzTyrValoxzOxzDhaThz & yes & yes $(7)$ & 3.66 \\
\hline s26 & LP-DhaThzAsn (NMe) ThzValoxzTyrValThzThzDhaThz & no & yes (s19) & 3.51 \\
\hline $\mathbf{s} 27$ & LP-DhaThzSer-----OxzPheThzTyrValThzThzDhaThz & no & yes $(\mathbf{s 2 0})$ & 4.37 \\
\hline $\mathbf{s} 28$ & LP-DhaOxzAsn (NMe) ThzPheThzTyrValThzThzDhaThz & no & yes (s21) & 4.22 \\
\hline $\mathbf{s} 29$ & LP-DhaThzAsn (NMe) ThzValThzGlyValThzThzDhaoxzPro & no & yes $(\mathbf{s 2 2})$ & 1.60 \\
\hline s30 & LP-DhaOxzAsn (NMe) ThzValThzGlyValoxzOxzDhaOxzPro & yes & yes (s23) & -0.08 \\
\hline $\mathbf{s 3 1}$ & LP-DhaOxzSer-----OxzValoxzTyrValoxzOxzDhaOxz & yes & no (s24) & 0.87 \\
\hline
\end{tabular}

Table S1 Summary of Cyclizations with Variant Substrates. A compound was considered observed if the expected mass $(\mathrm{m} / \mathrm{z})$ could be extracted and associated with a UV peak at $254 \mathrm{~nm}$ (see Figure S1). LP $=15$-residue leader peptide sequence, Dha $=$ dehydroalanine, $\mathrm{Thz}=$ thiazole, $\mathrm{Oxz}=$ oxazole. AlogP values were calculated in MaestroElements (Maestro Core 10.7.014). 


\section{Figure $\mathrm{S1}$ - Thiopeptides with 29-membered macrocycles}


Figure S1 Thiopeptides with 29-membered macrocycles. These structures showcase the diverse structures found within the macrocyles for this particular family of thiopeptides. 


\section{Figure S2 - Cyclization Assays with Thiazole-to-Oxazole Substitutions}


Thiopeptide product (P)

Figure S2a Results of Oxazole Substitution in Substrates. LC-MS traces indicate the presence of linear substrate $(\mathrm{S})$, hemiaminal intermediate (I) and/or thiopeptide product $(\mathrm{P})$. 

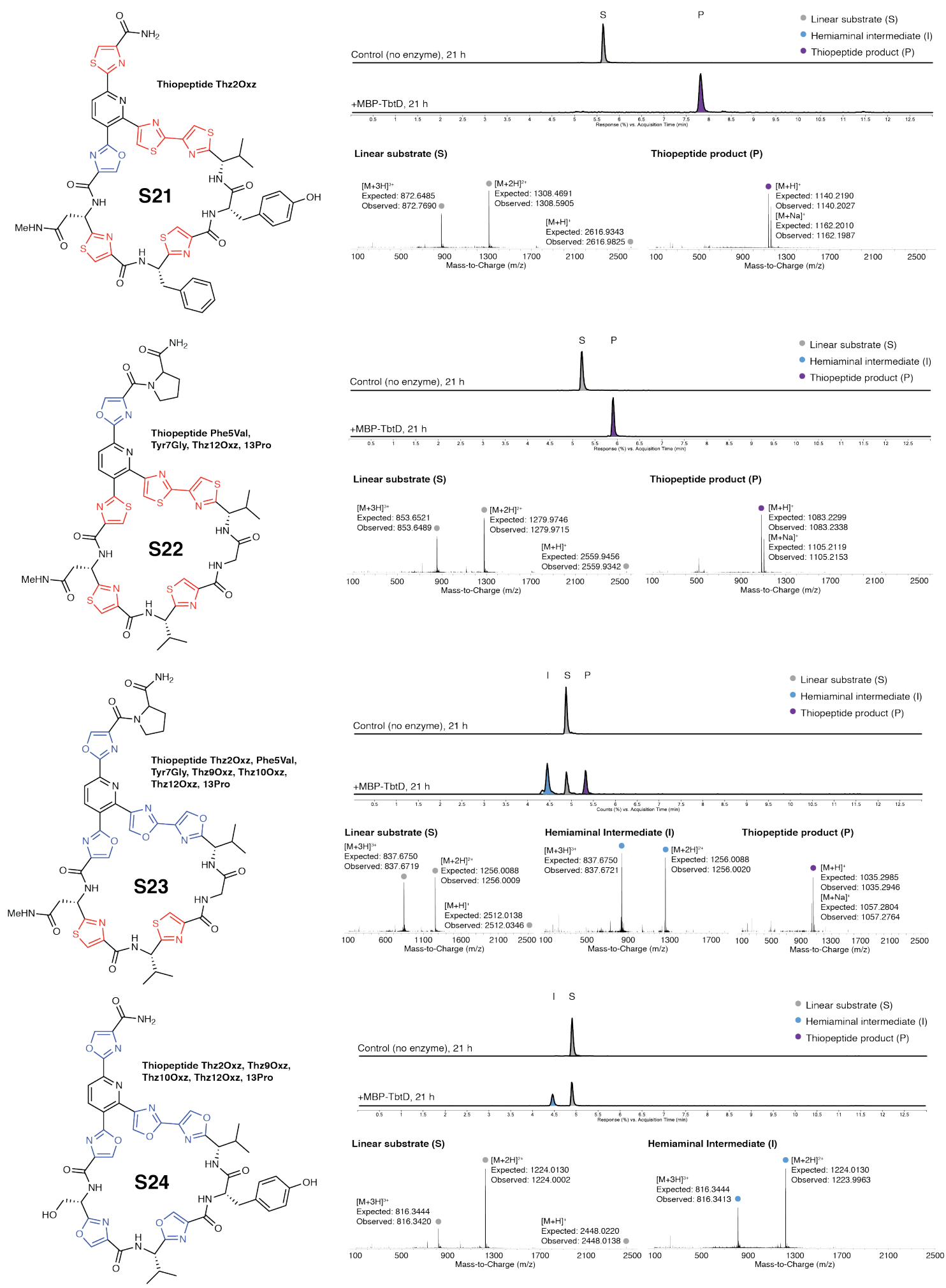

Figure S2b Results of Oxazole Substitution in Substrates. LC-MS traces indicate the presence of linear substrate $(\mathrm{S})$, hemiaminal intermediate (I) and/or thiopeptide product (P). 


\section{Figure S3 - Time Courses of (4) at pHs 8.5-10.5}

a. Time course at $\mathrm{pH} 8.5$
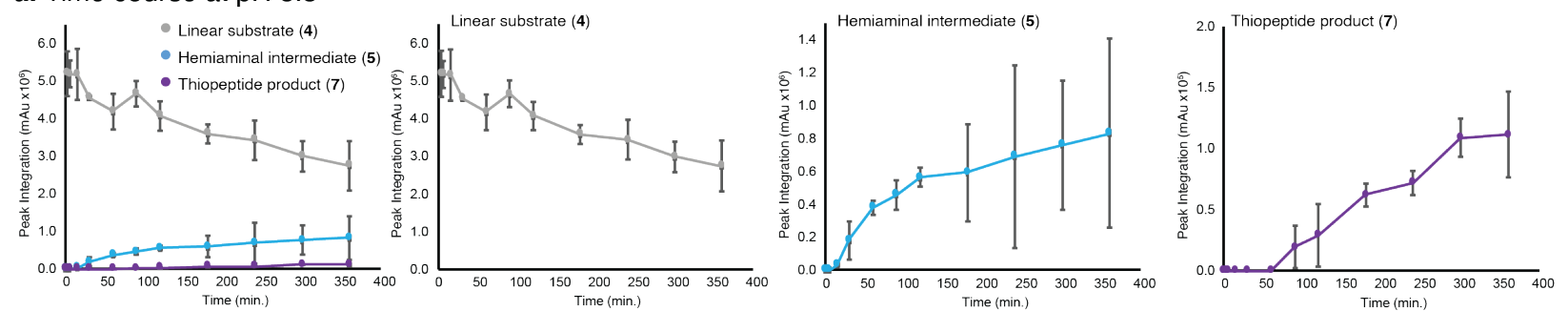

b. Time course at $\mathrm{pH} 9.0$
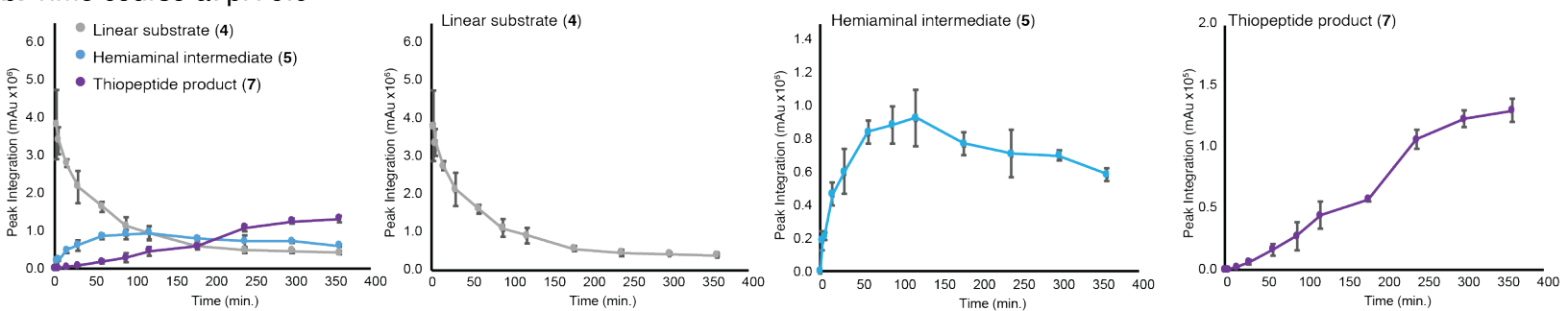

c. Time course at $\mathrm{pH} 9.5$
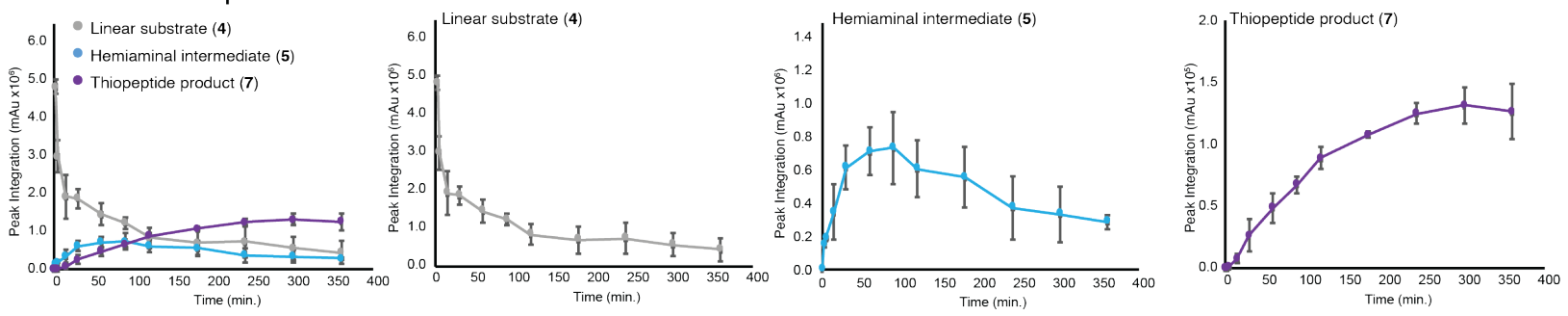

d. Time course at $\mathrm{pH} 10.0$
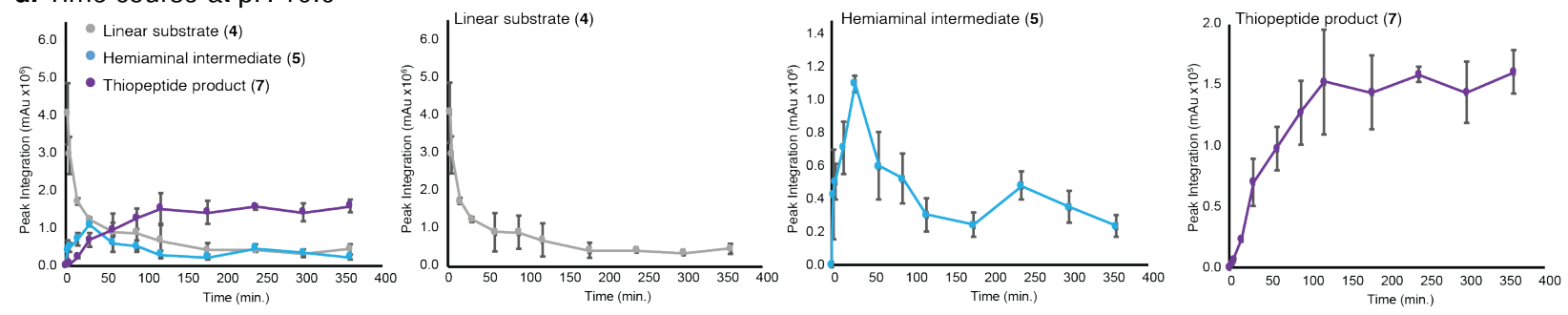

e. Time course at $\mathrm{pH} 10.5$
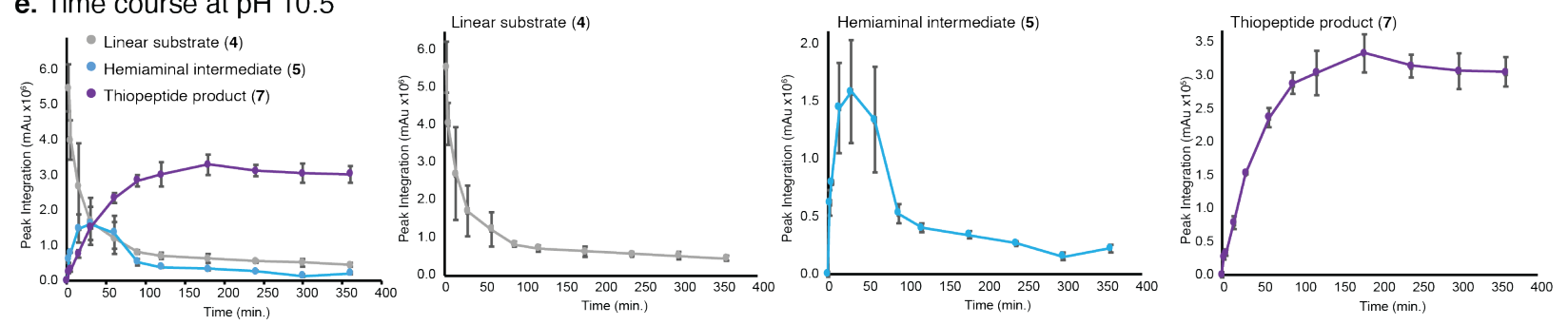

Figure S3 Time Course of (4) at pH 8.5-10.5 Each time point was analyzed by analytical RP-HPLC. The area under the peaks associate with the linear substrate (4), hemiaminal intermediate (5), and thiopeptide product (7) were plotted. All time courses were performed in triplicate. Error is represented in standard deviation. 


\section{Synthesis and Isolation of ${ }^{13} C$-Labeled Intermediate (6') and Thiopeptide (7')}

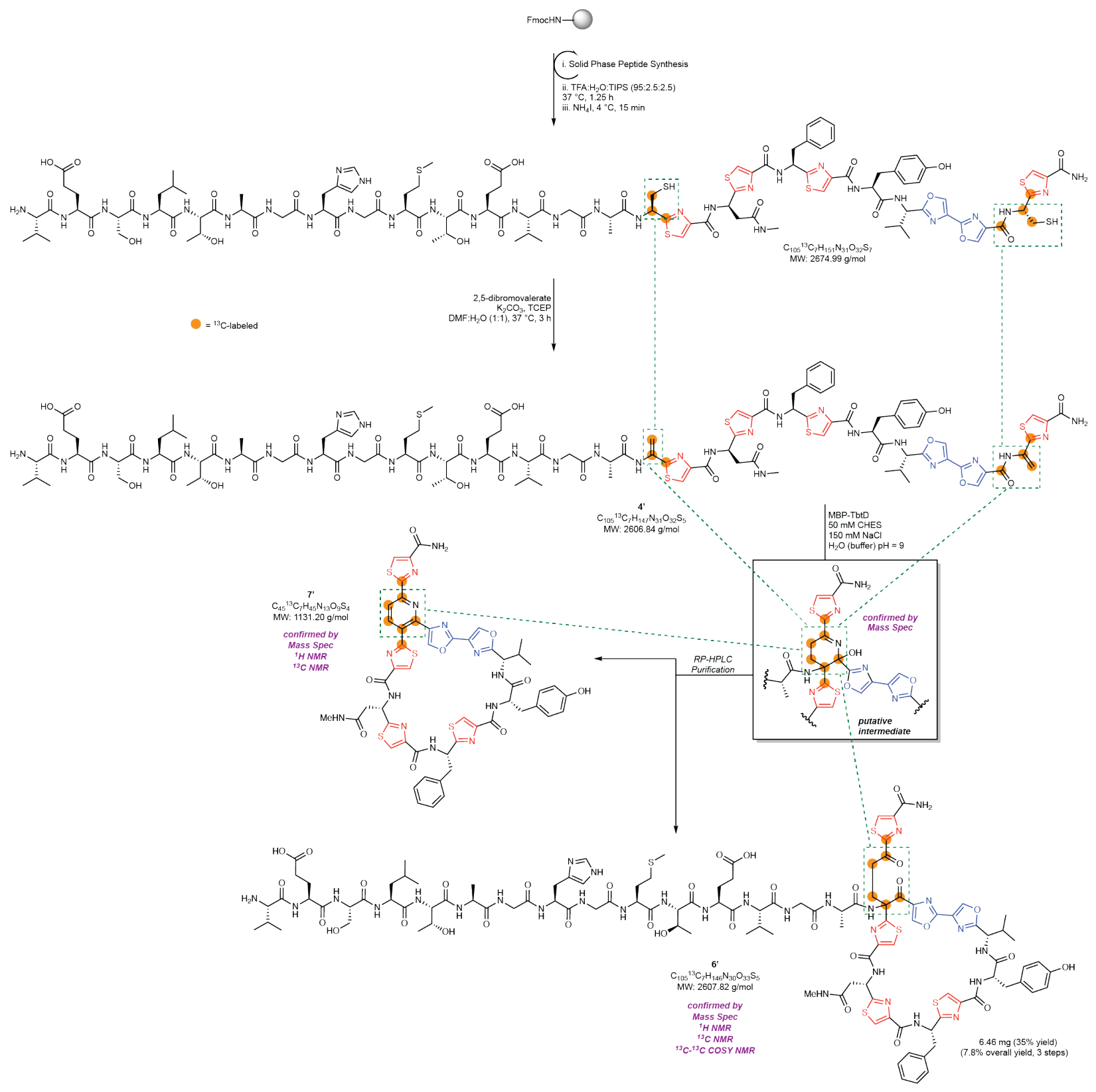

\section{Solid Phase Peptide Synthesis:}

In a 10-mL solid phase peptide synthesis vessel was swollen $200 \mathrm{mg}$ of H-Rink Amide ChemMatrix ${ }^{\circledR}$ resin in DMF:DCM (1:1)(5 mL) for 1 hour, followed by a standard deprotection sequence using a solution of piperidine $(20 \%$ in DMF $(v / v))$ for 10 minutes and the vessel was drained and washed with DMF (4 $\times 5 \mathrm{~mL})$ and DCM $(2 \times 5 \mathrm{~mL})$. To the deprotected resin was added a pre-activated solution of Fmoc-AA-OH (2-5 equivalents), HCTU (2-5 equivalents), and DIPEA (4-10 equivalents) in $2 \mathrm{~mL}$ of DMF and the reaction was stirred at room temperature for 
30-45 minutes per amino acid (2 equivalents of ${ }^{13} \mathrm{C}$-labeled azole building blocks were used, 3 equivalents for unlabeled azole building blocks, and 5 equivalents for commercially available building blocks). Each coupling was followed with a standard washing step, standard deprotection step, and another standard washing step. The synthesis was carried out to complete the construction of the peptide.

The peptide-bound resin was washed several times with DMF:DCM (1:1) and briefly vacuum dried prior to being transferred to a $50-\mathrm{mL}$ conical tube. The resin was cleaved by agitating in a standard cleavage cocktail of TFA:TIPS: $\mathrm{H}_{2} \mathrm{O}(95: 2.5: 2.5,25 \mathrm{~mL})$ at $37^{\circ} \mathrm{C}$ for 75 minutes. The solution was then frozen by placing it in dry ice for several minutes. A methionine sulfoxide reduction was conducted by adding $\sim 15$ equivalents of ammonium iodide ( $200 \mathrm{mgs})$ to the frozen resin. The tube containing the resin was simultaneously shaken and thawed at $4{ }^{\circ} \mathrm{C}$ for 15 minutes. The resin was then filtered from the cleavage cocktail solution and the resulting filtrate was concentrated to a total volume of $\sim 4 \mathrm{~mL}$ under a stream of nitrogen. Approximately $45 \mathrm{~mL}$ of $\mathrm{Et}_{2} \mathrm{O}$ was added to the vessel to crash out the peptide from the solution (to bring the total volume close to $50 \mathrm{~mL}$ ), after which the vessel was then placed in the $-80^{\circ} \mathrm{C}$ freezer for 30 minutes to facilitate precipitation of the peptide. The crude peptide was then pelleted by centrifugation (10 minutes at $1500 \mathrm{rpm}$ at $4{ }^{\circ} \mathrm{C}$ ) and the $\mathrm{Et}_{2} \mathrm{O}$ was carefully decanted to provide a crude white solid. The crude material was dissolved in $\sim 2.5 \mathrm{~mL}$ of DMF and then diluted with $\sim 22 \mathrm{~mL}$ of $\mathrm{MeCN}_{\mathrm{H}} \mathrm{\textrm {O }}(1: 1)$ to render the material fully soluble, and a small amount (2-5 equiv.) of TCEP was added to maintain the dithiol.

The peptide-containing solution was purified by RP-HPLC eluting a gradient of $0-100 \%$ $\mathrm{MeCN} / \mathrm{H}_{2} \mathrm{O}(+1 \%$ TFA) over 5 injections. Fractions predicted to contain the desired product were taken into scintillation vials, frozen, and lyophilized overnight to dryness, providing the cleaved linear precursor (72.1 mg, $26.9 \mu \mathrm{mol}, 28 \%$ yield) as a white solid.

\section{Dehydroalanine Installation:}

In a $50-\mathrm{mL}$ conical tube was added $4.25 \mathrm{~mL}$ of a solution of this peptide $(72.1 \mathrm{mg}, 26.9 \mu \mathrm{mol})$ (6.33 mM in DMF), $17.55 \mathrm{~mL}$ of DMF, $15.00 \mathrm{~mL}$ of $\mathrm{H}_{2} \mathrm{O}$, and $1.74 \mathrm{~mL}$ of a $0.1 \mathrm{M}$ TCEP solution in $\mathrm{H}_{2} \mathrm{O}$. The reaction was incubated and agitated at $37^{\circ} \mathrm{C}$ for 30 minutes after which $5.34 \mathrm{~mL}$ of a 
$0.5 \mathrm{M} \mathrm{K}_{2} \mathrm{CO}_{3}$ solution in $\mathrm{H}_{2} \mathrm{O}$ and $0.24 \mathrm{~mL}$ of methyl 2,5-dibromovalerate ${ }^{6}$ were added. The vessel was briefly vortexed to ensure mixing and then agitated at $37^{\circ} \mathrm{C}$ for 3 hours. The peptidecontaining solution was purified by RP-HPLC eluting a gradient of $0-100 \% \mathrm{MeCN} / \mathrm{H}_{2} \mathrm{O}(+1 \%$ TFA) over 10 injections. Fractions predicted to contain the desired product were taken into scintillation vials, frozen, and lyophilized overnight to dryness, providing 4' (18.7 mg, 7.16 $\mu \mathrm{mol}$, $27 \%$ yield) as a white solid.

\section{Enzymatic Cyclization:}

In a $50-\mathrm{mL}$ conical tube, $1.40 \mathrm{~mL}$ of a solution of 4' (18.7 mg, $7.16 \mu \mathrm{mol}), 0.01 \mathrm{M}$ in DMF) was diluted into $27.0 \mathrm{~mL}$ of buffer solution (50 mM CHES, $150 \mathrm{mM} \mathrm{NaCl}, \mathrm{pH}$ 9.0) followed by the addition of $6.26 \mathrm{~mL}$ of MBP-TbtD (10mg/mL in buffer). The tube was gently pipetted up and down to ensure complete homogeneity of the reaction solution. The tube was then centrifuged briefly at $200 \mathrm{rpm}$ for 20 seconds to remove all of the bubbles and was then let sit on the benchtop and monitored by either LCMS or analytical HPLC (in order to maximize the intermediate yield and avoid further conversion to the thiopeptide product). When peak concentrations of the intermediate were reached, the reaction solution was quenched by the addition of $30 \mathrm{mLs}$ of $\mathrm{MeOH}$ (to crash out the TbtD). ${ }^{7}$ The solutions were centrifuged to pellet all insoluble enzyme at $4000 \mathrm{rpm}$ for 10 minutes. The solutions were then decanted to separate from the insoluble TbtD pellet and concentrated in vacuo (MeOH removal) to render approximately $25 \mathrm{~mL}$ of remaining solution. The peptide-containing solution was purified by RP-HPLC eluting a gradient of $0-100 \%$ $\mathrm{MeCN} / \mathrm{H}_{2} \mathrm{O}(+1 \% \mathrm{TFA})$ over 5 runs. Fractions predicted to contain the desired intermediate, product, and recovered starting material were taken into scintillation vials, frozen, and lyophilized overnight to dryness. Recovered from the purification was the desired intermediate 6' (6.46 mg, $2.48 \mu \mathrm{mol}$, 35\% yield), starting material 4' (8.11 mg, $3.11 \mu \mathrm{mol}, 43 \%$ recovery), and thiopeptide product 7' (1.59 mg, $1.41 \mu \mathrm{mol}, 20 \%$ yield).

\footnotetext{
${ }^{6}$ Compound was synthesized via a protocol from Morrison, P; Foley, P; Warriner, S.; Webb, M. Chem. Commun. 2015, 51, 13470-13473

${ }^{7}$ Prior to quenching, the $\sim 35 \mathrm{mLs}$ of reaction solution were first split into two different conical tubes to account for the large volume.
} 


\section{Figure S4 - Stacked ${ }^{13} \mathrm{C}$-Labeled ${ }^{1} \mathrm{H}$ NMRs}

${ }^{1} \mathrm{H}$ NMR Stack



$\begin{array}{lllllllllllllllllllllll}11.0 & 10.5 & 10.0 & 9.5 & 9.0 & 8.5 & 8.0 & 7.5 & 7.0 & 6.5 & \begin{array}{c}6.0 \\ \text { chemical shift }\end{array} \begin{array}{l}5.5 \\ \text { (ppm) }\end{array} & 4.5 & 4.0 & 3.5 & 3.0 & 2.5 & 2.0 & 1.5 & 1.0 & 0.5 & 0.0\end{array}$

Figure S4 Stacked ${ }^{13} \mathrm{C}$-Labeled ${ }^{1} \mathbf{H}$ NMRs. ${ }^{1} \mathrm{H}$ NMRs of the ${ }^{13} \mathrm{C}$-labeled linear substrate, diketone intermediate and thiopeptide product are stacked. All spectra were taken in DMSO- $d_{6}$. 


\section{Figure S5 - Stacked ${ }^{13} \mathrm{C}$-Labeled ${ }^{13} \mathrm{C}$ NMRs}

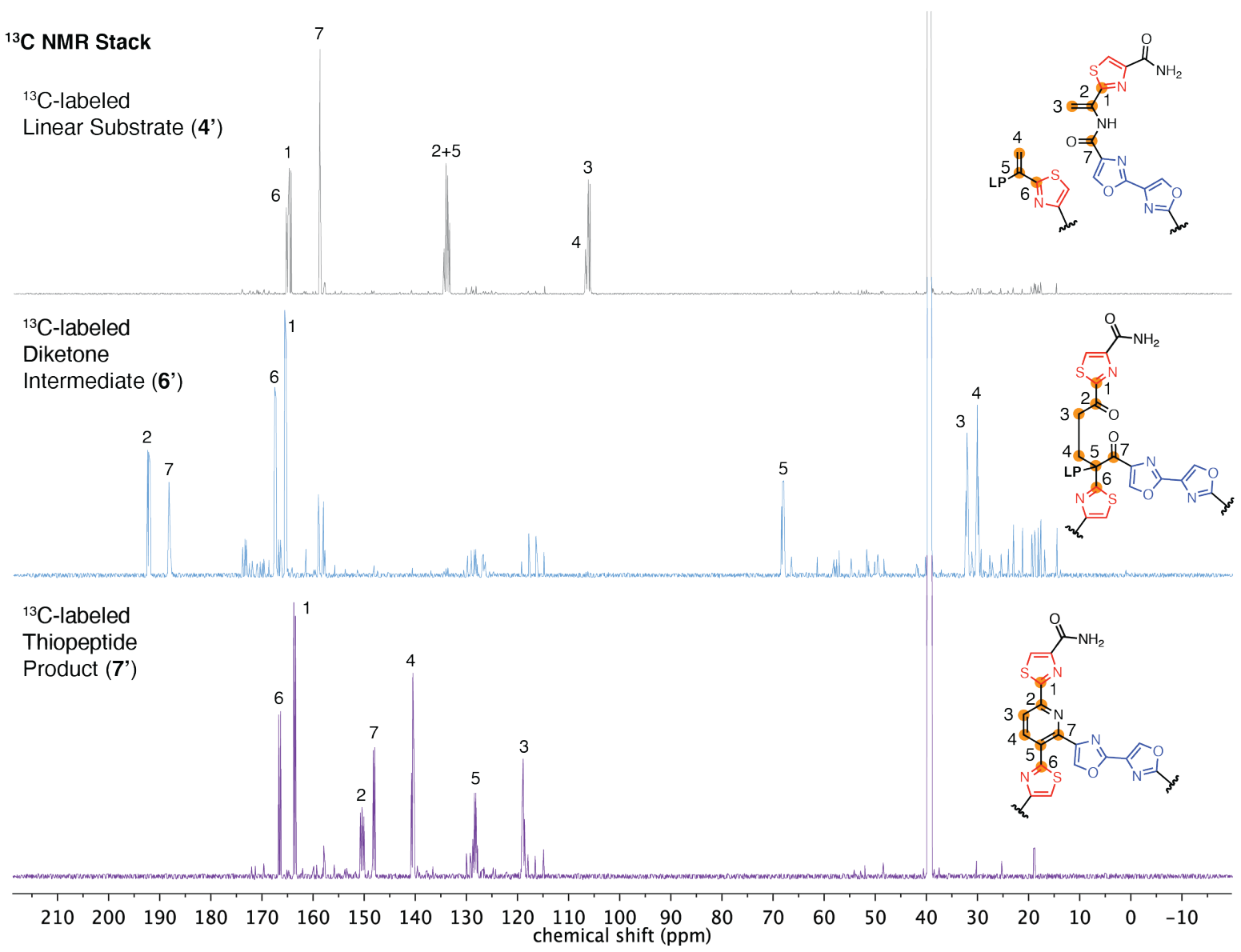

Figure S5 Stacked ${ }^{13} \mathrm{C}$-Labeled ${ }^{13} \mathrm{C}$ NMRs. ${ }^{13} \mathrm{C}$ NMRs of the ${ }^{13} \mathrm{C}$-labeled linear substrate, diketone intermediate and thiopeptide product are stacked. All spectra were taken in DMSO- $d_{6}$. 


\section{Figure S6 - NMR calculations}

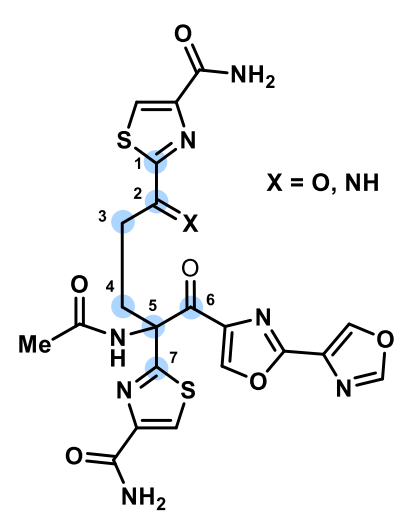

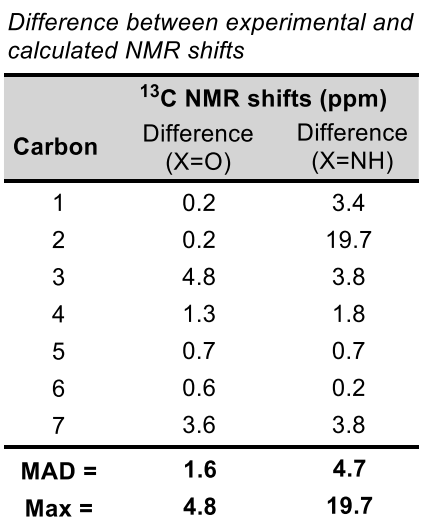

Figure $\mathbf{S 6}$ Calculated NMR shifts for two potential intermediates ${ }^{\mathrm{a}}$

${ }^{a} \mathrm{MAD}=$ mean average deviation. ${ }^{b} \mathrm{Max}=$ maximum deviation

\section{NMR calculations}

In order to evaluate the possibility of the ketone or imine intermediates, we conducted NMR calculations. Deviations between experimental and calculated ${ }^{13} \mathrm{C}$ NMR shifts are shown for both structures. Calculations of the carbonyl intermediate closely match experimental data, with a mean average deviation (MAD) of $1.6 \mathrm{ppm}$, and a maximum deviation (Max) of $4.8 \mathrm{ppm}$. Conversely, calculated shifts of the corresponding imine structure deviated from the experimental shifts to a greater extent, particularly at the C2 position, which marks the location of the carbonyl/imine carbon. These results support the assignment of the intermediate as the carbonyl compound.

\section{General Information}

A conformational search was performed on both structures $(X=O, X=N H)$ using MacroModel. 46 and 45 conformers were generated for the $\mathrm{X}=\mathrm{O}$ and $\mathrm{X}=\mathrm{NH}$ compounds, respectively. Geometry optimizations and frequency calculations were performed on each structure using Gaussian using $B 3 L Y P / 6-31+G(d, p)$. The Boltzman distribution and mole fractions of the structures was computed. Structures that were within $4 \mathrm{kcal} / \mathrm{mol}$ of the lowest-energy structure (which corresponds to a mol fraction of 0.001 ) were carried on to the next steps. For the $X=0$ compound, this consisted of seven structures. For the $\mathrm{X}=\mathrm{NH}$ compound, it consisted of 8 structures. NMR calculations were performed on each optimized structure using mPW1PW91/6- 
$311+\mathrm{G}(2 \mathrm{~d}, \mathrm{p})$ with DMSO solvation. The calculated isotropic values were scaled using scaling factors developed by Pierins et al. $^{8}$ The scaling factors used were as follow:

$\begin{array}{ll}\text { slope: } & -1.0496 \\ \text { intercept: } & 186.2534\end{array}$

The contribution of each structure's NMR shifts towards the overall NMR shift was determined based on the mole fraction of each compound.

\section{Coordinates of optimized geometries}

$\begin{array}{lrrr}\text { NMR: O } & & & \\ \text { 1 } & & & \\ \text { C } & 0.886681 & 1.562322 & -0.138437 \\ \text { N } & 1.885578 & 2.363368 & 0.110074 \\ \text { C } & 2.433788 & 2.866154 & -1.049265 \\ \text { C } & 1.841117 & 2.436464 & -2.207930 \\ \text { S } & 0.539302 & 1.371454 & -1.846463 \\ \text { C } & 0.110756 & 0.878738 & 0.986158 \\ \text { N } & -0.731741 & 1.850396 & 1.684702 \\ \text { C } & 1.156344 & 0.417561 & 2.050440 \\ \text { C } & -1.785067 & 2.523223 & 1.150548 \\ \text { O } & -2.174359 & 2.348311 & -0.008315 \\ \text { C } & 2.204798 & -0.543765 & 1.672038 \\ \text { O } & 1.090609 & 0.833544 & 3.199779 \\ \text { C } & -0.712210 & -0.340004 & 0.475723 \\ \text { C } & -1.478108 & -1.070867 & 1.596668 \\ \text { C } & -2.316483 & -2.222356 & 1.064732 \\ \text { C } & -3.531072 & -1.879298 & 0.281838 \\ \text { O } & -2.025733 & -3.393720 & 1.264975 \\ \text { N } & -3.895838 & -0.661909 & -0.032388 \\ \text { C } & -5.046807 & -0.658523 & -0.771746 \\ \text { C } & -5.580005 & -1.905263 & -1.019987 \\ \text { S } & -4.606432 & -3.133421 & -0.320220 \\ \text { C } & -5.659042 & 0.610259 & -1.285338 \\ \text { O } & -6.743194 & 0.585812 & -1.869418 \\ \text { N } & -4.942698 & 1.738095 & -1.061803 \\ \text { C } & 3.592496 & 3.809306 & -1.013440 \\ \text { N } & 4.024399 & 4.126924 & 0.237620 \\ \text { O } & 4.100358 & 4.249212 & -2.042385 \\ \text { C } & 3.153173 & -1.054424 & 2.516636 \\ \text { O } & 3.939271 & -1.894801 & 1.803148 \\ \text { C } & 3.430832 & -1.863898 & 0.531401 \\ \text { N } & 2.402219 & -1.078694 & 0.404109 \\ \text { C } & 4.070604 & -2.672220 & -0.485987\end{array}$

${ }^{8}$ Pierens, G. K. J. Comput. Chem. 2014, 35, 1388-1394 


\begin{tabular}{|c|c|c|c|}
\hline$N$ & 5.162854 & -3.496776 & -0.226273 \\
\hline C & 5.432429 & -4.035259 & -1.369890 \\
\hline 0 & 4.612290 & -3.642890 & -2.384194 \\
\hline C & 3.741343 & -2.767384 & -1.807729 \\
\hline C & -2.465861 & 3.516494 & 2.074299 \\
\hline $\mathrm{H}$ & 2.106898 & 2.711348 & -3.218648 \\
\hline $\mathrm{H}$ & -0.429837 & 2.047080 & 2.633507 \\
\hline $\mathrm{H}$ & -0.027404 & -1.029765 & -0.022755 \\
\hline $\mathrm{H}$ & -1.427688 & 0.039687 & -0.255658 \\
\hline $\mathrm{H}$ & -2.138029 & -0.361443 & 2.106406 \\
\hline $\mathrm{H}$ & -0.794763 & -1.505847 & 2.331605 \\
\hline $\mathrm{H}$ & -6.482184 & -2.119154 & -1.575775 \\
\hline $\mathrm{H}$ & -5.309316 & 2.595766 & -1.448054 \\
\hline $\mathrm{H}$ & -4.010540 & 1.747607 & -0.654737 \\
\hline $\mathrm{H}$ & 3.565189 & 3.747772 & 1.052494 \\
\hline $\mathrm{H}$ & 4.796941 & 4.768130 & 0.333891 \\
\hline $\mathrm{H}$ & 3.376799 & -0.924803 & 3.562773 \\
\hline $\mathrm{H}$ & 6.210170 & -4.742174 & -1.615486 \\
\hline $\mathrm{H}$ & 2.989556 & -2.320632 & -2.436643 \\
\hline $\mathrm{H}$ & -3.530480 & 3.272684 & 2.128731 \\
\hline $\mathrm{H}$ & -2.048908 & 3.533284 & 3.084428 \\
\hline $\mathrm{H}$ & -2.377943 & 4.514800 & 1.635453 \\
\hline \multicolumn{4}{|l|}{2} \\
\hline C & 0.900695 & 1.560727 & -0.148323 \\
\hline$N$ & 1.879895 & 2.387789 & 0.098163 \\
\hline C & 2.438009 & 2.871107 & -1.064415 \\
\hline C & 1.873972 & 2.398516 & -2.221221 \\
\hline$S$ & 0.590898 & 1.315102 & -1.854212 \\
\hline C & 0.122345 & 0.889495 & 0.982559 \\
\hline$N$ & -0.715402 & 1.869934 & 1.674845 \\
\hline C & 1.169536 & 0.436238 & 2.047016 \\
\hline C & -1.762630 & 2.547134 & 1.134051 \\
\hline $\mathrm{O}$ & -2.153797 & 2.365665 & -0.022903 \\
\hline C & 2.212549 & -0.533492 & 1.670238 \\
\hline $\mathrm{O}$ & 1.116477 & 0.865231 & 3.192140 \\
\hline C & -0.706594 & -0.330118 & 0.483801 \\
\hline C & -1.469671 & -1.047890 & 1.615098 \\
\hline C & -2.317127 & -2.201732 & 1.103574 \\
\hline C & -3.524206 & -1.863501 & 0.306890 \\
\hline $\mathrm{O}$ & -2.041994 & -3.371382 & 1.333935 \\
\hline$N$ & -3.882696 & -0.648892 & -0.024371 \\
\hline C & -5.030056 & -0.650197 & -0.769312 \\
\hline C & -5.566648 & -1.897831 & -1.005108 \\
\hline$S$ & -4.601625 & -3.120866 & -0.284786 \\
\hline C & -5.634738 & 0.614768 & -1.300685 \\
\hline
\end{tabular}




\begin{tabular}{|c|c|c|c|}
\hline 0 & -6.715909 & 0.587874 & -1.890455 \\
\hline $\mathrm{N}$ & -4.915715 & 1.742450 & -1.085501 \\
\hline C & 3.574917 & 3.839412 & -1.031799 \\
\hline $\mathrm{N}$ & 3.978102 & 4.195213 & 0.219466 \\
\hline 0 & 4.093152 & 4.267513 & -2.060676 \\
\hline C & 3.177273 & -1.026387 & 2.504499 \\
\hline 0 & 3.946787 & -1.884548 & 1.788990 \\
\hline C & 3.403704 & -1.877746 & 0.522628 \\
\hline $\mathrm{N}$ & 2.378272 & -1.093029 & 0.407819 \\
\hline C & 4.035168 & -2.724578 & -0.467830 \\
\hline $\mathrm{N}$ & 3.571851 & -2.810806 & -1.778573 \\
\hline C & 4.375654 & -3.648574 & -2.344275 \\
\hline 0 & 5.348512 & -4.139987 & -1.525524 \\
\hline C & 5.120984 & -3.540516 & -0.322479 \\
\hline C & -2.434758 & 3.554820 & 2.048915 \\
\hline $\mathrm{H}$ & 2.153958 & 2.648083 & -3.234572 \\
\hline $\mathrm{H}$ & -0.409345 & 2.077882 & 2.619653 \\
\hline $\mathrm{H}$ & -0.027848 & -1.025743 & -0.014753 \\
\hline $\mathrm{H}$ & -1.423818 & 0.048611 & -0.246158 \\
\hline $\mathrm{H}$ & -2.124268 & -0.330930 & 2.121688 \\
\hline $\mathrm{H}$ & -0.784784 & -1.478035 & 2.351588 \\
\hline $\mathrm{H}$ & -6.466184 & -2.115164 & -1.563797 \\
\hline $\mathrm{H}$ & -5.275974 & 2.596740 & -1.484958 \\
\hline $\mathrm{H}$ & -3.985377 & 1.753018 & -0.674365 \\
\hline $\mathrm{H}$ & 3.505449 & 3.832195 & 1.033988 \\
\hline $\mathrm{H}$ & 4.727958 & 4.862986 & 0.313528 \\
\hline $\mathrm{H}$ & 3.425332 & -0.874369 & 3.542096 \\
\hline $\mathrm{H}$ & 4.372651 & -4.000878 & -3.364553 \\
\hline $\mathrm{H}$ & 5.784581 & -3.788146 & 0.489384 \\
\hline $\mathrm{H}$ & -2.018976 & 3.575831 & 3.059512 \\
\hline $\mathrm{H}$ & -2.336167 & 4.548520 & 1.601921 \\
\hline $\mathrm{H}$ & -3.501821 & 3.322151 & 2.103842 \\
\hline \multicolumn{4}{|l|}{3} \\
\hline C & -0.878926 & 1.673851 & 0.507089 \\
\hline$N$ & -1.446700 & 2.132318 & -0.572271 \\
\hline C & -2.166312 & 3.284295 & -0.318253 \\
\hline C & -2.141658 & 3.711203 & 0.981405 \\
\hline$S$ & -1.185182 & 2.644560 & 1.940064 \\
\hline C & -0.003964 & 0.426801 & 0.548331 \\
\hline $\mathrm{N}$ & -0.123855 & -0.214819 & -0.756956 \\
\hline C & -0.540637 & -0.507918 & 1.690540 \\
\hline C & 0.384442 & -1.442290 & -1.044861 \\
\hline 0 & 1.023611 & -2.101207 & -0.218710 \\
\hline C & -1.800598 & -1.253746 & 1.483843 \\
\hline 0 & 0.045995 & -0.576493 & 2.756023 \\
\hline
\end{tabular}




\begin{tabular}{|c|c|c|c|}
\hline C & 1.472837 & 0.794002 & 0.876203 \\
\hline C & 2.131049 & 1.670212 & -0.204934 \\
\hline C & 3.606795 & 1.912555 & 0.063687 \\
\hline C & 4.530451 & 0.757367 & -0.088824 \\
\hline $\mathrm{O}$ & 4.047784 & 3.007906 & 0.383231 \\
\hline$N$ & 4.162052 & -0.464711 & -0.380275 \\
\hline C & 5.235859 & -1.311189 & -0.437237 \\
\hline C & 6.455969 & -0.717929 & -0.194162 \\
\hline$S$ & 6.263238 & 0.955295 & 0.134736 \\
\hline C & 5.080691 & -2.775621 & -0.716323 \\
\hline $\mathrm{O}$ & 6.071607 & -3.489525 & -0.874029 \\
\hline$N$ & 3.804140 & -3.229174 & -0.777114 \\
\hline C & -2.904032 & 4.003916 & -1.401169 \\
\hline$N$ & -2.773001 & 3.460965 & -2.644368 \\
\hline $\mathrm{O}$ & -3.579125 & 5.001512 & -1.164930 \\
\hline C & -2.281627 & -2.230928 & 2.310950 \\
\hline $\mathrm{O}$ & -3.468783 & -2.656181 & 1.811969 \\
\hline C & -3.671037 & -1.901051 & 0.689337 \\
\hline$N$ & -2.707463 & -1.061029 & 0.446232 \\
\hline C & -4.893852 & -2.098443 & -0.063414 \\
\hline$N$ & -5.807340 & -3.111470 & 0.220559 \\
\hline C & -6.742788 & -2.951268 & -0.656984 \\
\hline $\mathrm{O}$ & -6.540203 & -1.911728 & -1.512974 \\
\hline C & -5.351034 & -1.368698 & -1.122969 \\
\hline C & 0.130514 & -1.953992 & -2.449194 \\
\hline $\mathrm{H}$ & -2.631000 & 4.582000 & 1.393508 \\
\hline $\mathrm{H}$ & -0.756321 & 0.233523 & -1.407455 \\
\hline $\mathrm{H}$ & 2.016127 & -0.144122 & 0.985725 \\
\hline $\mathrm{H}$ & 1.495723 & 1.300642 & 1.844250 \\
\hline $\mathrm{H}$ & 1.660626 & 2.655440 & -0.264595 \\
\hline $\mathrm{H}$ & 2.035601 & 1.175603 & -1.177598 \\
\hline $\mathrm{H}$ & 7.420051 & -1.206837 & -0.196185 \\
\hline $\mathrm{H}$ & 3.679931 & -4.224778 & -0.889353 \\
\hline $\mathrm{H}$ & 2.993037 & -2.664289 & -0.540320 \\
\hline $\mathrm{H}$ & -2.140112 & 2.692789 & -2.806217 \\
\hline H & -3.189640 & 3.947912 & -3.423780 \\
\hline $\mathrm{H}$ & -1.917712 & -2.700070 & 3.210110 \\
\hline $\mathrm{H}$ & -7.645351 & -3.527566 & -0.792332 \\
\hline $\mathrm{H}$ & -4.992468 & -0.508580 & -1.663119 \\
\hline $\mathrm{H}$ & -0.382312 & -2.917522 & -2.382616 \\
\hline H & -0.463858 & -1.271839 & -3.062335 \\
\hline $\mathrm{H}$ & 1.093999 & -2.125594 & -2.938141 \\
\hline \multicolumn{4}{|l|}{4} \\
\hline C & 1.760121 & 1.639134 & -0.350612 \\
\hline $\mathrm{N}$ & 2.587795 & 1.961362 & 0.604071 \\
\hline
\end{tabular}




\begin{tabular}{|c|c|c|c|}
\hline C & 3.836790 & 2.270833 & 0.112631 \\
\hline C & 3.965804 & 2.181696 & -1.248727 \\
\hline S & 2.471064 & 1.703236 & -1.953034 \\
\hline C & 0.308503 & 1.260517 & -0.051954 \\
\hline$N$ & -0.423955 & 2.440012 & 0.406719 \\
\hline C & 0.333219 & 0.296380 & 1.178362 \\
\hline C & -0.654616 & 3.560673 & -0.338087 \\
\hline $\mathrm{O}$ & -0.348446 & 3.647430 & -1.526440 \\
\hline C & 1.135673 & -0.934476 & 1.126406 \\
\hline $\mathrm{O}$ & -0.315729 & 0.569163 & 2.180500 \\
\hline C & -0.381922 & 0.587502 & -1.280361 \\
\hline C & -1.894757 & 0.377841 & -1.150869 \\
\hline C & -2.322035 & -0.886364 & -0.430824 \\
\hline C & -3.770621 & -1.032999 & -0.126691 \\
\hline 0 & -1.549847 & -1.783897 & -0.122937 \\
\hline $\mathrm{N}$ & -4.701649 & -0.156628 & -0.409204 \\
\hline C & -5.935071 & -0.595738 & -0.003149 \\
\hline C & -5.944577 & -1.832126 & 0.603421 \\
\hline$S$ & -4.359280 & -2.482944 & 0.673171 \\
\hline C & -7.169186 & 0.224497 & -0.214763 \\
\hline $\mathrm{O}$ & -8.270785 & -0.170789 & 0.157297 \\
\hline $\mathrm{N}$ & -6.960483 & 1.413666 & -0.840010 \\
\hline C & 4.950222 & 2.669748 & 1.025379 \\
\hline$N$ & 4.612554 & 2.709483 & 2.343480 \\
\hline $\mathrm{O}$ & 6.072978 & 2.935705 & 0.601432 \\
\hline C & 1.231261 & -1.860960 & 2.127275 \\
\hline 0 & 2.046711 & -2.855504 & 1.700367 \\
\hline C & 2.419439 & -2.487184 & 0.435220 \\
\hline$N$ & 1.906489 & -1.356323 & 0.051332 \\
\hline C & 3.315106 & -3.356365 & -0.300686 \\
\hline$N$ & 3.789516 & -4.565495 & 0.203577 \\
\hline C & 4.545750 & -5.027199 & -0.737524 \\
\hline $\mathrm{O}$ & 4.623906 & -4.230907 & -1.839432 \\
\hline C & 3.830628 & -3.159660 & -1.549395 \\
\hline C & -1.314628 & 4.710279 & 0.404831 \\
\hline $\mathrm{H}$ & 4.848934 & 2.387692 & -1.836307 \\
\hline $\mathrm{H}$ & -0.678843 & 2.413649 & 1.388156 \\
\hline $\mathrm{H}$ & 0.120262 & -0.359996 & -1.486721 \\
\hline $\mathrm{H}$ & -0.222038 & 1.259229 & -2.126462 \\
\hline $\mathrm{H}$ & -2.336100 & 0.317850 & -2.155165 \\
\hline $\mathrm{H}$ & -2.385456 & 1.236972 & -0.683881 \\
\hline $\mathrm{H}$ & -6.808903 & -2.350857 & 0.993881 \\
\hline H & -7.753490 & 2.010812 & -1.019360 \\
\hline $\mathrm{H}$ & -6.035445 & 1.689318 & -1.134162 \\
\hline $\mathrm{H}$ & 3.674996 & 2.482548 & 2.640542 \\
\hline
\end{tabular}




\begin{tabular}{|c|c|c|c|}
\hline $\mathrm{H}$ & 5.316814 & 2.972989 & 3.015500 \\
\hline $\mathrm{H}$ & 0.806334 & -1.949477 & 3.113264 \\
\hline $\mathrm{H}$ & 5.111165 & -5.946375 & -0.757386 \\
\hline $\mathrm{H}$ & 3.744432 & -2.383927 & -2.291589 \\
\hline $\mathrm{H}$ & -2.113824 & 5.118980 & -0.217770 \\
\hline $\mathrm{H}$ & -1.718869 & 4.426579 & 1.380435 \\
\hline $\mathrm{H}$ & -0.571304 & 5.501007 & 0.549495 \\
\hline \multicolumn{4}{|l|}{5} \\
\hline C & 0.307540 & -0.165278 & -1.132393 \\
\hline $\mathrm{N}$ & -0.183249 & 0.865372 & -0.501203 \\
\hline C & -0.357208 & 1.942448 & -1.349016 \\
\hline C & 0.010198 & 1.723832 & -2.649148 \\
\hline$S$ & 0.595018 & 0.115703 & -2.839743 \\
\hline C & 0.576704 & -1.507573 & -0.463378 \\
\hline $\mathrm{N}$ & 0.663674 & -1.254313 & 0.973197 \\
\hline C & 1.931267 & -2.067431 & -1.019217 \\
\hline C & 1.153196 & -2.171990 & 1.856823 \\
\hline $\mathrm{O}$ & 1.494984 & -3.300476 & 1.505469 \\
\hline C & 3.200389 & -1.436102 & -0.593079 \\
\hline $\mathrm{O}$ & 1.939543 & -2.963927 & -1.844321 \\
\hline C & -0.548652 & -2.538142 & -0.788032 \\
\hline C & -1.925463 & -2.168206 & -0.226198 \\
\hline C & -2.765357 & -1.264879 & -1.111516 \\
\hline C & -3.895421 & -0.538986 & -0.467660 \\
\hline $\mathrm{O}$ & -2.588044 & -1.140736 & -2.314989 \\
\hline $\mathrm{N}$ & -4.201234 & -0.568636 & 0.805471 \\
\hline C & -5.296265 & 0.213654 & 1.070005 \\
\hline C & -5.834401 & 0.855000 & -0.023397 \\
\hline$S$ & -4.951195 & 0.472548 & -1.442784 \\
\hline C & -5.849949 & 0.342067 & 2.453875 \\
\hline $\mathrm{O}$ & -6.814074 & 1.063377 & 2.695157 \\
\hline$N$ & -5.197529 & -0.390849 & 3.397116 \\
\hline C & -0.918438 & 3.238080 & -0.860792 \\
\hline$N$ & -1.278202 & 3.247638 & 0.453750 \\
\hline $\mathrm{O}$ & -1.034615 & 4.210998 & -1.601385 \\
\hline C & 4.450718 & -1.926282 & -0.847432 \\
\hline $\mathrm{O}$ & 5.356015 & -1.059420 & -0.326690 \\
\hline C & 4.607215 & -0.055908 & 0.222704 \\
\hline$N$ & 3.324233 & -0.235325 & 0.098812 \\
\hline C & 5.294761 & 1.060058 & 0.841680 \\
\hline$N$ & 6.677579 & 1.106021 & 1.007417 \\
\hline C & 6.891065 & 2.242160 & 1.585770 \\
\hline $\mathrm{O}$ & 5.767229 & 2.972374 & 1.825875 \\
\hline C & 4.746733 & 2.205704 & 1.343086 \\
\hline C & 1.250293 & -1.714631 & 3.300790 \\
\hline
\end{tabular}




\begin{tabular}{|c|c|c|c|}
\hline $\mathrm{H}$ & -0.044501 & 2.423731 & -3.470448 \\
\hline $\mathrm{H}$ & 0.529095 & -0.294568 & 1.262635 \\
\hline $\mathrm{H}$ & -0.224459 & -3.487859 & -0.358449 \\
\hline $\mathrm{H}$ & -0.603281 & -2.673864 & -1.869443 \\
\hline $\mathrm{H}$ & -1.859023 & -1.736901 & 0.776093 \\
\hline $\mathrm{H}$ & -2.518291 & -3.086468 & -0.104640 \\
\hline $\mathrm{H}$ & -6.690961 & 1.514475 & -0.026298 \\
\hline $\mathrm{H}$ & -5.552898 & -0.385395 & 4.341270 \\
\hline $\mathrm{H}$ & -4.443812 & -1.009836 & 3.138165 \\
\hline $\mathrm{H}$ & -1.227969 & 2.406806 & 1.008383 \\
\hline $\mathrm{H}$ & -1.715395 & 4.077529 & 0.825315 \\
\hline $\mathrm{H}$ & 4.825647 & -2.811090 & -1.334547 \\
\hline $\mathrm{H}$ & 7.830486 & 2.674229 & 1.895390 \\
\hline $\mathrm{H}$ & 3.746742 & 2.598730 & 1.418253 \\
\hline $\mathrm{H}$ & 0.738969 & -2.444137 & 3.934331 \\
\hline $\mathrm{H}$ & 2.304530 & -1.707274 & 3.593324 \\
\hline $\mathrm{H}$ & 0.825217 & -0.722557 & 3.475385 \\
\hline \multicolumn{4}{|l|}{6} \\
\hline C & -0.282694 & -0.209961 & 1.169161 \\
\hline$N$ & 0.186829 & 0.876606 & 0.622184 \\
\hline C & 0.393911 & 1.868171 & 1.561569 \\
\hline C & 0.071696 & 1.527226 & 2.847127 \\
\hline$S$ & -0.511951 & -0.091368 & 2.905434 \\
\hline C & -0.574812 & -1.486255 & 0.388111 \\
\hline$N$ & -0.686076 & -1.109523 & -1.018811 \\
\hline C & -1.918485 & -2.079217 & 0.932076 \\
\hline C & -1.227213 & -1.939759 & -1.957381 \\
\hline $\mathrm{O}$ & -1.564970 & -3.093496 & -1.691741 \\
\hline C & -3.199956 & -1.430122 & 0.569805 \\
\hline $\mathrm{O}$ & -1.910967 & -3.012914 & 1.715813 \\
\hline C & 0.548927 & -2.548786 & 0.596702 \\
\hline C & 1.914068 & -2.141017 & 0.032858 \\
\hline C & 2.790744 & -1.334796 & 0.974136 \\
\hline C & 3.929908 & -0.589025 & 0.370346 \\
\hline $\mathrm{O}$ & 2.635427 & -1.303404 & 2.186646 \\
\hline$N$ & 4.220083 & -0.532670 & -0.905359 \\
\hline C & 5.331789 & 0.239275 & -1.126766 \\
\hline C & 5.898957 & 0.785106 & 0.003120 \\
\hline$S$ & 5.022599 & 0.321730 & 1.402514 \\
\hline C & 5.871725 & 0.454947 & -2.505107 \\
\hline $\mathrm{O}$ & 6.856931 & 1.160210 & -2.706152 \\
\hline$N$ & 5.183546 & -0.183339 & -3.490456 \\
\hline C & 0.935782 & 3.207233 & 1.179139 \\
\hline$N$ & 1.229958 & 3.348772 & -0.142495 \\
\hline $\mathrm{O}$ & 1.102201 & 4.096462 & 2.010518 \\
\hline
\end{tabular}




\begin{tabular}{|c|c|c|c|}
\hline C & -4.437313 & -1.884679 & 0.927438 \\
\hline $\mathrm{O}$ & -5.360922 & -1.016947 & 0.435099 \\
\hline C & -4.626118 & -0.048971 & -0.208336 \\
\hline$N$ & -3.345803 & -0.251299 & -0.156531 \\
\hline C & -5.365567 & 1.029142 & -0.833333 \\
\hline$N$ & -4.742737 & 2.032056 & -1.574352 \\
\hline C & -5.714032 & 2.792319 & -1.959115 \\
\hline $\mathrm{O}$ & -6.946715 & 2.389972 & -1.542932 \\
\hline C & -6.712299 & 1.255878 & -0.820534 \\
\hline C & -1.397834 & -1.345357 & -3.342357 \\
\hline $\mathrm{H}$ & 0.156280 & 2.147099 & 3.727989 \\
\hline $\mathrm{H}$ & -0.597942 & -0.121659 & -1.220001 \\
\hline $\mathrm{H}$ & 0.205872 & -3.455584 & 0.094849 \\
\hline $\mathrm{H}$ & 0.628805 & -2.776662 & 1.660804 \\
\hline $\mathrm{H}$ & 1.823390 & -1.613611 & -0.920501 \\
\hline $\mathrm{H}$ & 2.491662 & -3.048358 & -0.196044 \\
\hline $\mathrm{H}$ & 6.771668 & 1.421790 & 0.042540 \\
\hline $\mathrm{H}$ & 5.519817 & -0.109631 & -4.438632 \\
\hline $\mathrm{H}$ & 4.404717 & -0.785370 & -3.268498 \\
\hline $\mathrm{H}$ & 1.057992 & 2.598465 & -0.793931 \\
\hline $\mathrm{H}$ & 1.583663 & 4.236374 & -0.465667 \\
\hline $\mathrm{H}$ & -4.793814 & -2.739863 & 1.477255 \\
\hline $\mathrm{H}$ & -5.669929 & 3.689563 & -2.557628 \\
\hline $\mathrm{H}$ & -7.563801 & 0.758601 & -0.386657 \\
\hline $\mathrm{H}$ & -1.110026 & -2.093651 & -4.083976 \\
\hline $\mathrm{H}$ & -2.457124 & -1.112891 & -3.492495 \\
\hline $\mathrm{H}$ & -0.817186 & -0.431817 & -3.495791 \\
\hline \multicolumn{4}{|l|}{7} \\
\hline C & -2.393268 & 0.441788 & 0.551043 \\
\hline$N$ & -3.374696 & -0.305434 & 0.127636 \\
\hline C & -3.939183 & -1.034199 & 1.150921 \\
\hline C & -3.373525 & -0.841929 & 2.384169 \\
\hline S & -2.094210 & 0.303316 & 2.274888 \\
\hline C & -1.610524 & 1.352423 & -0.398249 \\
\hline$N$ & -2.418674 & 2.513125 & -0.766981 \\
\hline C & -1.433956 & 0.547714 & -1.727626 \\
\hline C & -2.846654 & 3.485581 & 0.091189 \\
\hline $\mathrm{O}$ & -2.515933 & 3.527416 & 1.275843 \\
\hline C & -0.666068 & -0.708384 & -1.721423 \\
\hline $\mathrm{O}$ & -1.934055 & 0.957922 & -2.764616 \\
\hline C & -0.245480 & 1.781394 & 0.216793 \\
\hline C & 0.621813 & 2.697838 & -0.686898 \\
\hline C & 1.669253 & 1.950506 & -1.489485 \\
\hline C & 2.891093 & 1.496853 & -0.768251 \\
\hline $\mathrm{O}$ & 1.553259 & 1.703045 & -2.681911 \\
\hline
\end{tabular}




$\begin{array}{lrrr}\text { N } & 3.160402 & 1.720552 & 0.493542 \\ \mathrm{C} & 4.363138 & 1.167110 & 0.849888 \\ \mathrm{C} & 5.025730 & 0.508589 & -0.161956 \\ \mathrm{~S} & 4.123433 & 0.576448 & -1.619339 \\ \mathrm{C} & 4.898643 & 1.283407 & 2.242780 \\ \mathrm{O} & 5.971420 & 0.775785 & 2.559210 \\ \mathrm{~N} & 4.105995 & 1.979650 & 3.100355 \\ \mathrm{C} & -5.083379 & -1.961940 & 0.899863 \\ \mathrm{~N} & -5.510055 & -1.995041 & -0.392109 \\ \mathrm{O} & -5.583082 & -2.632566 & 1.800613 \\ \mathrm{C} & -0.400540 & -1.481210 & -2.817875 \\ \mathrm{O} & 0.328479 & -2.548726 & -2.410695 \\ \mathrm{C} & 0.481771 & -2.380216 & -1.061079 \\ \mathrm{~N} & -0.086437 & -1.302206 & -0.605665 \\ \mathrm{C} & 1.219739 & -3.381891 & -0.318736 \\ \mathrm{~N} & 1.857844 & -4.462177 & -0.924517 \\ \mathrm{C} & 2.390440 & -5.108741 & 0.060006 \\ \mathrm{O} & 2.165862 & -4.555898 & 1.284042 \\ \mathrm{C} & 1.412356 & -3.448127 & 1.031538 \\ \mathrm{C} & -3.770905 & 4.527034 & -0.516353 \\ \mathrm{H} & -3.665362 & -1.304077 & 3.316340 \\ \mathrm{H} & -2.755034 & 2.491272 & -1.724109 \\ \mathrm{H} & 0.304959 & 0.884732 & 0.505934 \\ \mathrm{H} & -0.487517 & 2.336265 & 1.125037 \\ \mathrm{H} & 1.134501 & 3.420617 & -0.046167 \\ \mathrm{H} & -0.002331 & 3.249468 & -1.394385 \\ \mathrm{H} & 5.982496 & 0.010878 & -0.087560 \\ \mathrm{H} & 4.419706 & 2.109995 & 4.050274 \\ \mathrm{H} & 3.240954 & 2.393962 & 2.786662 \\ \mathrm{H} & -5.071687 & -1.416530 & -1.093604 \\ \mathrm{H} & -6.285980 & -2.593848 & -0.629791 \\ \mathrm{H} & -0.631978 & -1.400954 & -3.867042 \\ \mathrm{H} & 2.978427 & -6.013466 & 0.032509 \\ \mathrm{H} & 1.106804 & -2.847550 & 1.871908 \\ \mathrm{H} & -3.397277 & 5.520821 & -0.257429 \\ \mathrm{H} & -3.868605 & 4.446930 & -1.602288 \\ & -4.760863 & 4.418557 & -0.062346\end{array}$

NMR: NH

1

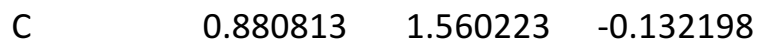

$\begin{array}{llll}\mathrm{N} & 1.886040 & 2.354508 & 0.113680\end{array}$

$\begin{array}{llll}\text { C } & 2.437612 & 2.849343 & -1.047504\end{array}$ 


\begin{tabular}{|c|c|c|c|}
\hline C & 1.841247 & 2.419867 & -2.204470 \\
\hline$S$ & 0.531439 & 1.366270 & -1.839056 \\
\hline C & 0.101924 & 0.884495 & 0.995246 \\
\hline$N$ & -0.729469 & 1.863561 & 1.696635 \\
\hline C & 1.147312 & 0.414420 & 2.054157 \\
\hline C & -1.769075 & 2.554359 & 1.156896 \\
\hline 0 & -2.148434 & 2.391108 & -0.006211 \\
\hline C & 2.196582 & -0.545314 & 1.668864 \\
\hline 0 & 1.085662 & 0.820897 & 3.207235 \\
\hline C & -0.733607 & -0.327810 & 0.488585 \\
\hline C & -1.510107 & -1.049456 & 1.607362 \\
\hline C & -2.339469 & -2.213306 & 1.090055 \\
\hline C & -3.533564 & -1.879441 & 0.287610 \\
\hline N & -2.099786 & -3.455178 & 1.298968 \\
\hline$N$ & -3.881957 & -0.663105 & -0.043672 \\
\hline C & -5.032588 & -0.654052 & -0.792193 \\
\hline C & -5.578765 & -1.892976 & -1.030236 \\
\hline$S$ & -4.623527 & -3.127111 & -0.306672 \\
\hline C & -5.624806 & 0.616232 & -1.320240 \\
\hline 0 & -6.700303 & 0.603924 & -1.921522 \\
\hline$N$ & -4.902478 & 1.740308 & -1.090230 \\
\hline C & 3.602884 & 3.784310 & -1.015263 \\
\hline$N$ & 4.034351 & 4.107215 & 0.234768 \\
\hline O & 4.116757 & 4.213511 & -2.045731 \\
\hline C & 3.163653 & -1.037034 & 2.503464 \\
\hline 0 & 3.947735 & -1.876954 & 1.786211 \\
\hline C & 3.418961 & -1.864697 & 0.522439 \\
\hline$N$ & 2.379570 & -1.092223 & 0.403753 \\
\hline C & 4.051520 & -2.675785 & -0.497287 \\
\hline$N$ & 5.141641 & -3.504471 & -0.241693 \\
\hline C & 5.404977 & -4.043633 & -1.386536 \\
\hline O & 4.582353 & -3.648003 & -2.397472 \\
\hline C & 3.716899 & -2.769374 & -1.817925 \\
\hline C & -2.446098 & 3.550308 & 2.080453 \\
\hline $\mathrm{H}$ & 2.108217 & 2.689881 & -3.216198 \\
\hline $\mathrm{H}$ & -0.430211 & 2.053184 & 2.647386 \\
\hline $\mathrm{H}$ & -0.056725 & -1.024595 & -0.011154 \\
\hline $\mathrm{H}$ & -1.447460 & 0.054542 & -0.242794 \\
\hline $\mathrm{H}$ & -2.176283 & -0.335579 & 2.102034 \\
\hline $\mathrm{H}$ & -0.825073 & -1.444483 & 2.366622 \\
\hline $\mathrm{H}$ & -1.261028 & -3.580646 & 1.870286 \\
\hline $\mathrm{H}$ & -6.478777 & -2.102818 & -1.590712 \\
\hline $\mathrm{H}$ & -5.254218 & 2.599052 & -1.487329 \\
\hline $\mathrm{H}$ & -3.977342 & 1.741991 & -0.669726 \\
\hline $\mathrm{H}$ & 4.808263 & 4.747153 & 0.328443 \\
\hline
\end{tabular}




\begin{tabular}{|c|c|c|c|}
\hline $\mathrm{H}$ & 3.567146 & 3.741053 & 1.051010 \\
\hline $\mathrm{H}$ & 3.404918 & -0.890961 & 3.543519 \\
\hline $\mathrm{H}$ & 6.179245 & -4.753246 & -1.635345 \\
\hline $\mathrm{H}$ & 2.965200 & -2.318704 & -2.444259 \\
\hline $\mathrm{H}$ & -3.511828 & 3.310796 & 2.133130 \\
\hline $\mathrm{H}$ & -2.030538 & 3.564230 & 3.091268 \\
\hline $\mathrm{H}$ & -2.353490 & 4.548367 & 1.642249 \\
\hline \multicolumn{4}{|l|}{2} \\
\hline C & 0.898075 & 1.563495 & -0.132874 \\
\hline$N$ & 1.900140 & 2.357446 & 0.125099 \\
\hline C & 2.459888 & 2.860370 & -1.028728 \\
\hline C & 1.872725 & 2.438385 & -2.192986 \\
\hline$S$ & 0.561756 & 1.380302 & -1.844159 \\
\hline C & 0.108160 & 0.880804 & 0.982332 \\
\hline $\mathrm{N}$ & -0.725981 & 1.859585 & 1.682028 \\
\hline C & 1.141515 & 0.402058 & 2.050289 \\
\hline C & -1.771460 & 2.542848 & 1.148804 \\
\hline $\mathrm{O}$ & -2.157335 & 2.379887 & -0.013381 \\
\hline C & 2.183537 & -0.566957 & 1.672648 \\
\hline $\mathrm{O}$ & 1.072042 & 0.809315 & 3.202638 \\
\hline C & -0.723616 & -0.326877 & 0.461397 \\
\hline C & -1.513698 & -1.049847 & 1.569210 \\
\hline C & -2.315451 & -2.221421 & 1.036119 \\
\hline C & -3.542336 & -1.888395 & 0.269200 \\
\hline$N$ & -1.898020 & -3.409823 & 1.274281 \\
\hline$N$ & -3.883585 & -0.670985 & -0.059792 \\
\hline C & -5.051035 & -0.639287 & -0.779481 \\
\hline C & -5.631887 & -1.863871 & -1.002332 \\
\hline$S$ & -4.685117 & -3.114542 & -0.296566 \\
\hline C & -5.635390 & 0.641401 & -1.296834 \\
\hline $\mathrm{O}$ & -6.723277 & 0.638640 & -1.875126 \\
\hline$N$ & -4.893058 & 1.753369 & -1.083535 \\
\hline C & 3.624378 & 3.795476 & -0.980842 \\
\hline$N$ & 4.048329 & 4.105928 & 0.274793 \\
\hline $\mathrm{O}$ & 4.143838 & 4.235746 & -2.004026 \\
\hline C & 3.106206 & -1.109359 & 2.525710 \\
\hline 0 & 3.894366 & -1.947526 & 1.811464 \\
\hline C & 3.413139 & -1.881903 & 0.530541 \\
\hline$N$ & 2.399434 & -1.078703 & 0.398405 \\
\hline C & 4.062583 & -2.676674 & -0.491573 \\
\hline $\mathrm{N}$ & 5.135291 & -3.525638 & -0.228688 \\
\hline C & 5.421530 & -4.040435 & -1.379173 \\
\hline $\mathrm{O}$ & 4.630783 & -3.609894 & -2.401216 \\
\hline C & 3.761443 & -2.733945 & -1.822080 \\
\hline C & -2.448800 & 3.535406 & 2.076216 \\
\hline
\end{tabular}




\begin{tabular}{|c|c|c|c|}
\hline $\mathrm{H}$ & 2.147556 & 2.715060 & -3.200775 \\
\hline H & -0.430313 & 2.042718 & 2.635470 \\
\hline $\mathrm{H}$ & -0.040566 & -1.027101 & -0.024927 \\
\hline $\mathrm{H}$ & -1.422402 & 0.059080 & -0.282791 \\
\hline $\mathrm{H}$ & -2.191117 & -0.341373 & 2.055369 \\
\hline $\mathrm{H}$ & -0.840246 & -1.460942 & 2.326387 \\
\hline $\mathrm{H}$ & -2.505356 & -4.125525 & 0.863067 \\
\hline $\mathrm{H}$ & -6.551144 & -2.059577 & -1.535763 \\
\hline $\mathrm{H}$ & -3.963582 & 1.749146 & -0.670163 \\
\hline $\mathrm{H}$ & -5.244864 & 2.618081 & -1.467866 \\
\hline $\mathrm{H}$ & 4.825880 & 4.739627 & 0.379642 \\
\hline $\mathrm{H}$ & 3.581472 & 3.724533 & 1.084302 \\
\hline $\mathrm{H}$ & 3.308683 & -1.005763 & 3.578987 \\
\hline $\mathrm{H}$ & 6.193162 & -4.753923 & -1.625055 \\
\hline $\mathrm{H}$ & 3.031603 & -2.258569 & -2.455803 \\
\hline $\mathrm{H}$ & -3.514997 & 3.297595 & 2.126639 \\
\hline $\mathrm{H}$ & -2.034389 & 3.544031 & 3.087518 \\
\hline $\mathrm{H}$ & -2.353846 & 4.535519 & 1.643030 \\
\hline \multicolumn{4}{|l|}{3} \\
\hline C & -0.864711 & 1.673601 & 0.505086 \\
\hline$N$ & -1.417051 & 2.143017 & -0.577525 \\
\hline C & -2.121310 & 3.305501 & -0.327249 \\
\hline C & -2.101195 & 3.729875 & 0.973187 \\
\hline$S$ & -1.169556 & 2.646402 & 1.938334 \\
\hline C & -0.003854 & 0.417230 & 0.551653 \\
\hline$N$ & -0.125863 & -0.226481 & -0.752180 \\
\hline C & -0.554418 & -0.506474 & 1.696082 \\
\hline C & 0.360777 & -1.466454 & -1.025606 \\
\hline $\mathrm{O}$ & 0.971417 & -2.132374 & -0.184305 \\
\hline C & -1.816772 & -1.247343 & 1.486084 \\
\hline $\mathrm{O}$ & 0.022181 & -0.567254 & 2.767518 \\
\hline C & 1.476245 & 0.770669 & 0.881860 \\
\hline C & 2.147283 & 1.639343 & -0.196456 \\
\hline C & 3.620304 & 1.888866 & 0.078379 \\
\hline C & 4.535437 & 0.738750 & -0.077383 \\
\hline$N$ & 4.141765 & 3.009515 & 0.417813 \\
\hline$N$ & 4.153355 & -0.478073 & -0.368034 \\
\hline C & 5.222002 & -1.337113 & -0.443307 \\
\hline C & 6.448178 & -0.759150 & -0.215131 \\
\hline$S$ & 6.274972 & 0.918406 & 0.122196 \\
\hline C & 5.047446 & -2.796889 & -0.725597 \\
\hline $\mathrm{O}$ & 6.025455 & -3.525700 & -0.898242 \\
\hline$N$ & 3.764162 & -3.237231 & -0.775020 \\
\hline C & -2.839021 & 4.038127 & -1.415136 \\
\hline $\mathrm{N}$ & -2.717338 & 3.487305 & -2.655262 \\
\hline
\end{tabular}




\begin{tabular}{|c|c|c|c|}
\hline 0 & -3.488815 & 5.053816 & -1.184582 \\
\hline C & -2.303242 & -2.222973 & 2.311650 \\
\hline 0 & -3.490853 & -2.643694 & 1.809677 \\
\hline C & -3.687806 & -1.887302 & 0.687200 \\
\hline $\mathrm{N}$ & -2.720668 & -1.050461 & 0.446661 \\
\hline C & -4.909328 & -2.080637 & -0.068747 \\
\hline$N$ & -5.831013 & -3.085305 & 0.218461 \\
\hline C & -6.762124 & -2.924399 & -0.663530 \\
\hline 0 & -6.549184 & -1.892010 & -1.525647 \\
\hline C & -5.357524 & -1.354870 & -1.134826 \\
\hline C & 0.121006 & -1.980594 & -2.431271 \\
\hline $\mathrm{H}$ & -2.582949 & 4.606063 & 1.382877 \\
\hline $\mathrm{H}$ & -0.740728 & 0.230988 & -1.412688 \\
\hline $\mathrm{H}$ & 2.013186 & -0.171223 & 0.990115 \\
\hline $\mathrm{H}$ & 1.502872 & 1.273743 & 1.851872 \\
\hline $\mathrm{H}$ & 1.651469 & 2.613475 & -0.276474 \\
\hline $\mathrm{H}$ & 2.056901 & 1.140756 & -1.167115 \\
\hline $\mathrm{H}$ & 3.432228 & 3.742148 & 0.491896 \\
\hline $\mathrm{H}$ & 7.407475 & -1.256785 & -0.230567 \\
\hline $\mathrm{H}$ & 3.628898 & -4.232095 & -0.879963 \\
\hline $\mathrm{H}$ & 2.965448 & -2.666161 & -0.515722 \\
\hline $\mathrm{H}$ & -2.116482 & 2.692449 & -2.810005 \\
\hline $\mathrm{H}$ & -3.131337 & 3.972239 & -3.437258 \\
\hline $\mathrm{H}$ & -1.942573 & -2.694597 & 3.210807 \\
\hline $\mathrm{H}$ & -7.668193 & -3.495294 & -0.798361 \\
\hline $\mathrm{H}$ & -4.990630 & -0.501432 & -1.679871 \\
\hline $\mathrm{H}$ & 1.089889 & -2.161853 & -2.905991 \\
\hline $\mathrm{H}$ & -0.400906 & -2.939413 & -2.368812 \\
\hline $\mathrm{H}$ & -0.458515 & -1.294808 & -3.054619 \\
\hline \multicolumn{4}{|l|}{4} \\
\hline C & 0.908105 & 1.564613 & -0.145115 \\
\hline $\mathrm{N}$ & 1.892043 & 2.384256 & 0.106926 \\
\hline C & 2.458479 & 2.865948 & -1.052367 \\
\hline C & 1.895860 & 2.399933 & -2.212501 \\
\hline$S$ & 0.603744 & 1.324755 & -1.852970 \\
\hline C & 0.118537 & 0.896288 & 0.979540 \\
\hline$N$ & -0.709381 & 1.884940 & 1.673069 \\
\hline C & 1.156213 & 0.427796 & 2.046095 \\
\hline C & -1.751523 & 2.569779 & 1.135357 \\
\hline 0 & -2.143761 & 2.396523 & -0.022988 \\
\hline C & 2.192110 & -0.550260 & 1.669979 \\
\hline 0 & 1.102378 & 0.850561 & 3.193615 \\
\hline C & -0.719752 & -0.313626 & 0.474550 \\
\hline C & -1.507052 & -1.020026 & 1.595021 \\
\hline C & -2.312693 & -2.198578 & 1.084317 \\
\hline
\end{tabular}




\begin{tabular}{|c|c|c|c|}
\hline C & -3.529739 & -1.875598 & 0.297716 \\
\hline$N$ & -1.908728 & -3.383859 & 1.358876 \\
\hline$N$ & -3.871743 & -0.661787 & -0.043193 \\
\hline C & -5.031058 & -0.638816 & -0.776063 \\
\hline C & -5.604746 & -1.866895 & -0.998038 \\
\hline$S$ & -4.661111 & -3.109672 & -0.274325 \\
\hline C & -5.613420 & 0.636779 & -1.307857 \\
\hline O & -6.696752 & 0.627987 & -1.894843 \\
\hline$N$ & -4.874650 & 1.751488 & -1.096805 \\
\hline C & 3.601979 & 3.825827 & -1.012233 \\
\hline$N$ & 4.003167 & 4.173747 & 0.241976 \\
\hline 0 & 4.127543 & 4.254443 & -2.037365 \\
\hline C & 3.134695 & -1.069881 & 2.513073 \\
\hline 0 & 3.905205 & -1.927578 & 1.797868 \\
\hline C & 3.385302 & -1.892115 & 0.522255 \\
\hline$N$ & 2.373102 & -1.091561 & 0.401786 \\
\hline C & 4.025388 & -2.730213 & -0.470382 \\
\hline$N$ & 3.585908 & -2.791318 & -1.790800 \\
\hline C & 4.392213 & -3.627801 & -2.354864 \\
\hline 0 & 5.344848 & -4.141863 & -1.526448 \\
\hline C & 5.100422 & -3.558987 & -0.318174 \\
\hline C & -2.417989 & 3.578278 & 2.053832 \\
\hline $\mathrm{H}$ & 2.182010 & 2.649690 & -3.224062 \\
\hline $\mathrm{H}$ & -0.406651 & 2.081828 & 2.621292 \\
\hline $\mathrm{H}$ & -0.042879 & -1.020925 & -0.010083 \\
\hline $\mathrm{H}$ & -1.420484 & 0.069018 & -0.269312 \\
\hline $\mathrm{H}$ & -2.182292 & -0.303727 & 2.073070 \\
\hline $\mathrm{H}$ & -0.832347 & -1.420811 & 2.356737 \\
\hline $\mathrm{H}$ & -2.518779 & -4.104638 & 0.960724 \\
\hline $\mathrm{H}$ & -6.516359 & -2.069515 & -1.541869 \\
\hline $\mathrm{H}$ & -3.947016 & 1.751084 & -0.679315 \\
\hline $\mathrm{H}$ & -5.223113 & 2.612190 & -1.492969 \\
\hline $\mathrm{H}$ & 3.523695 & 3.811650 & 1.052962 \\
\hline $\mathrm{H}$ & 4.756425 & 4.836826 & 0.341538 \\
\hline $\mathrm{H}$ & 3.364857 & -0.938927 & 3.557599 \\
\hline $\mathrm{H}$ & 4.405135 & -3.963380 & -3.380695 \\
\hline $\mathrm{H}$ & 5.746463 & -3.825650 & 0.501741 \\
\hline $\mathrm{H}$ & -3.485918 & 3.349769 & 2.110053 \\
\hline $\mathrm{H}$ & -2.000449 & 3.594959 & 3.063813 \\
\hline $\mathrm{H}$ & -2.316092 & 4.572619 & 1.609068 \\
\hline \multicolumn{4}{|c|}{5} \\
\hline C & -0.807388 & 1.828139 & 0.398989 \\
\hline$N$ & -1.630312 & 2.077463 & -0.579301 \\
\hline C & -2.264611 & 3.292324 & -0.416295 \\
\hline C & -1.914982 & 3.983405 & 0.712287 \\
\hline
\end{tabular}




\begin{tabular}{|c|c|c|c|}
\hline$S$ & -0.749534 & 3.093611 & 1.618497 \\
\hline C & 0.028801 & 0.557158 & 0.508064 \\
\hline $\mathrm{N}$ & -0.145546 & -0.169322 & -0.745339 \\
\hline C & -0.537114 & -0.253346 & 1.728994 \\
\hline C & 0.301532 & -1.436503 & -0.944878 \\
\hline $\mathrm{O}$ & 0.955689 & -2.048362 & -0.092684 \\
\hline C & -1.799200 & -1.017109 & 1.586967 \\
\hline $\mathrm{O}$ & 0.020658 & -0.203485 & 2.811181 \\
\hline C & 1.522921 & 0.879641 & 0.785466 \\
\hline C & 2.207139 & 1.624077 & -0.374569 \\
\hline C & 3.676575 & 1.883350 & -0.108038 \\
\hline C & 4.581347 & 0.708261 & -0.199725 \\
\hline$N$ & 4.052149 & 3.076310 & 0.172758 \\
\hline$N$ & 4.165939 & -0.518055 & -0.372917 \\
\hline C & 5.203777 & -1.414793 & -0.405185 \\
\hline C & 6.454583 & -0.864924 & -0.266307 \\
\hline$S$ & 6.341636 & 0.840714 & -0.075173 \\
\hline C & 4.977034 & -2.888630 & -0.558596 \\
\hline $\mathrm{O}$ & 5.931995 & -3.658020 & -0.676614 \\
\hline$N$ & 3.681718 & -3.286169 & -0.555067 \\
\hline C & -3.276327 & 3.784777 & -1.400916 \\
\hline$N$ & -3.569171 & 2.912610 & -2.404129 \\
\hline $\mathrm{O}$ & -3.789839 & 4.895540 & -1.292688 \\
\hline C & -2.352975 & -1.790263 & 2.568769 \\
\hline $\mathrm{O}$ & -3.509767 & -2.315703 & 2.087152 \\
\hline C & -3.613146 & -1.823300 & 0.806989 \\
\hline$N$ & -2.626244 & -1.054066 & 0.466944 \\
\hline C & -4.777351 & -2.220799 & 0.041304 \\
\hline$N$ & -4.983121 & -1.809473 & -1.274939 \\
\hline C & -6.105012 & -2.358480 & -1.607170 \\
\hline $\mathrm{O}$ & -6.679458 & -3.109007 & -0.627684 \\
\hline C & -5.819140 & -3.014771 & 0.427625 \\
\hline C & -0.039328 & -2.056314 & -2.285099 \\
\hline $\mathrm{H}$ & -2.287148 & 4.946336 & 1.031355 \\
\hline $\mathrm{H}$ & -0.842223 & 0.213101 & -1.373281 \\
\hline $\mathrm{H}$ & 2.025656 & -0.068036 & 0.975533 \\
\hline $\mathrm{H}$ & 1.586510 & 1.470064 & 1.703352 \\
\hline $\mathrm{H}$ & 1.744886 & 2.601087 & -0.540023 \\
\hline $\mathrm{H}$ & 2.110009 & 1.034339 & -1.291182 \\
\hline $\mathrm{H}$ & 5.060734 & 3.137192 & 0.344063 \\
\hline $\mathrm{H}$ & 7.399495 & -1.389252 & -0.270700 \\
\hline $\mathrm{H}$ & 2.897642 & -2.666212 & -0.369396 \\
\hline $\mathrm{H}$ & 3.509475 & -4.280087 & -0.593744 \\
\hline $\mathrm{H}$ & -3.203593 & 1.972190 & -2.393082 \\
\hline H & -4.296221 & 3.164518 & -3.056599 \\
\hline
\end{tabular}




\begin{tabular}{|c|c|c|c|}
\hline $\mathrm{H}$ & -2.064843 & -2.046730 & 3.574825 \\
\hline $\mathrm{H}$ & -6.632480 & -2.296632 & -2.546964 \\
\hline $\mathrm{H}$ & -6.080431 & -3.542201 & 1.329943 \\
\hline $\mathrm{H}$ & -0.607661 & -1.391727 & -2.940029 \\
\hline $\mathrm{H}$ & 0.890403 & -2.344129 & -2.784350 \\
\hline $\mathrm{H}$ & -0.618770 & -2.967203 & -2.110335 \\
\hline \multicolumn{4}{|l|}{6} \\
\hline C & -2.223476 & -1.040568 & -0.226709 \\
\hline $\mathrm{N}$ & -3.046780 & -2.048520 & -0.138746 \\
\hline C & -4.168441 & -1.867103 & -0.922575 \\
\hline C & -4.202165 & -0.692500 & -1.623339 \\
\hline$S$ & -2.788652 & 0.237528 & -1.296538 \\
\hline C & -0.908135 & -0.964583 & 0.546894 \\
\hline $\mathrm{N}$ & -0.636000 & -2.313579 & 1.027487 \\
\hline C & -1.194883 & -0.054604 & 1.816183 \\
\hline C & 0.387200 & -2.614502 & 1.880943 \\
\hline 0 & 1.265365 & -1.803963 & 2.179835 \\
\hline C & -1.101998 & 1.421084 & 1.755536 \\
\hline 0 & -1.532423 & -0.584621 & 2.858824 \\
\hline C & 0.254902 & -0.430320 & -0.336358 \\
\hline C & 0.655255 & -1.402293 & -1.464445 \\
\hline C & 1.767241 & -0.844553 & -2.336839 \\
\hline C & 3.114723 & -0.791575 & -1.734599 \\
\hline$N$ & 1.640752 & -0.422978 & -3.541198 \\
\hline $\mathrm{N}$ & 3.380135 & -1.155700 & -0.507603 \\
\hline C & 4.709679 & -0.998280 & -0.208539 \\
\hline C & 5.480852 & -0.509350 & -1.236071 \\
\hline$S$ & 4.517332 & -0.221708 & -2.633171 \\
\hline C & 5.249490 & -1.322862 & 1.149926 \\
\hline 0 & 6.455916 & -1.238600 & 1.385849 \\
\hline$N$ & 4.324704 & -1.702163 & 2.066451 \\
\hline C & -5.260644 & -2.887191 & -0.985295 \\
\hline$N$ & -5.080712 & -3.971584 & -0.183228 \\
\hline 0 & -6.235258 & -2.735444 & -1.716747 \\
\hline C & -1.205007 & 2.242630 & 2.845642 \\
\hline 0 & -1.082611 & 3.523444 & 2.420814 \\
\hline C & -0.915413 & 3.434197 & 1.066638 \\
\hline$N$ & -0.919535 & 2.210433 & 0.624286 \\
\hline C & -0.752667 & 4.658726 & 0.309389 \\
\hline$N$ & -0.845713 & 5.924123 & 0.884823 \\
\hline C & -0.644369 & 6.736516 & -0.100059 \\
\hline 0 & -0.421923 & 6.126176 & -1.296993 \\
\hline C & -0.492064 & 4.792027 & -1.024456 \\
\hline C & 0.382343 & -4.026092 & 2.435253 \\
\hline $\mathrm{H}$ & -4.982389 & -0.351446 & -2.288735 \\
\hline
\end{tabular}




\begin{tabular}{|c|c|c|c|}
\hline $\mathrm{H}$ & -1.416167 & -2.955237 & 0.964100 \\
\hline $\mathrm{H}$ & 1.114008 & -0.258900 & 0.312048 \\
\hline $\mathrm{H}$ & -0.039124 & 0.532252 & -0.756793 \\
\hline $\mathrm{H}$ & -0.203000 & -1.618357 & -2.111172 \\
\hline $\mathrm{H}$ & 0.990117 & -2.347067 & -1.027625 \\
\hline $\mathrm{H}$ & 0.674511 & -0.513103 & -3.864113 \\
\hline $\mathrm{H}$ & 6.544108 & -0.316916 & -1.209851 \\
\hline $\mathrm{H}$ & 4.652192 & -1.879488 & 3.004421 \\
\hline $\mathrm{H}$ & 3.324663 & -1.704068 & 1.887535 \\
\hline $\mathrm{H}$ & -4.294199 & -4.026442 & 0.445347 \\
\hline $\mathrm{H}$ & -5.806223 & -4.671996 & -0.152496 \\
\hline $\mathrm{H}$ & -1.345574 & 2.074124 & 3.900459 \\
\hline $\mathrm{H}$ & -0.631142 & 7.815752 & -0.091407 \\
\hline $\mathrm{H}$ & -0.336273 & 4.106673 & -1.840735 \\
\hline $\mathrm{H}$ & -0.325645 & -4.689859 & 1.931855 \\
\hline $\mathrm{H}$ & 1.389264 & -4.441928 & 2.352629 \\
\hline $\mathrm{H}$ & 0.126976 & -3.976090 & 3.498597 \\
\hline \multicolumn{4}{|c|}{7} \\
\hline C & -1.529230 & -1.502183 & -0.411115 \\
\hline$N$ & -2.750606 & -1.927110 & -0.239744 \\
\hline C & -3.418461 & -2.051135 & -1.437991 \\
\hline C & -2.690710 & -1.711120 & -2.548457 \\
\hline$S$ & -1.104244 & -1.228396 & -2.090252 \\
\hline C & -0.582710 & -1.288997 & 0.770033 \\
\hline N & -0.123396 & -2.576800 & 1.289013 \\
\hline C & -1.431418 & -0.666859 & 1.924002 \\
\hline C & 0.652278 & -3.470601 & 0.608982 \\
\hline 0 & 1.133264 & -3.231953 & -0.498381 \\
\hline C & -2.084915 & 0.637841 & 1.726092 \\
\hline 0 & -1.534518 & -1.247286 & 2.996624 \\
\hline C & 0.601292 & -0.345300 & 0.410845 \\
\hline C & 1.566433 & -0.091633 & 1.586481 \\
\hline C & 2.635891 & 0.916471 & 1.217852 \\
\hline C & 3.857374 & 0.452127 & 0.501345 \\
\hline$N$ & 2.451111 & 2.148165 & 1.513459 \\
\hline$N$ & 4.769483 & 1.270180 & 0.037347 \\
\hline C & 5.801139 & 0.595147 & -0.562529 \\
\hline C & 5.686822 & -0.774359 & -0.564202 \\
\hline$S$ & 4.229148 & -1.244162 & 0.211215 \\
\hline C & 6.962520 & 1.318845 & -1.169455 \\
\hline 0 & 7.889651 & 0.712805 & -1.700322 \\
\hline$N$ & 6.896305 & 2.674158 & -1.079854 \\
\hline C & -4.835208 & -2.523053 & -1.489234 \\
\hline$N$ & -5.373834 & -2.825635 & -0.276304 \\
\hline 0 & -5.447367 & -2.621645 & -2.550477 \\
\hline
\end{tabular}




\begin{tabular}{|c|c|c|c|}
\hline C & -2.791891 & 1.321095 & 2.678146 \\
\hline 0 & -3.241278 & 2.470734 & 2.120997 \\
\hline C & -2.783097 & 2.442087 & 0.830333 \\
\hline$N$ & -2.092485 & 1.377267 & 0.549104 \\
\hline C & -3.108953 & 3.551662 & -0.041874 \\
\hline$N$ & -3.847790 & 4.656589 & 0.375140 \\
\hline C & -3.919566 & 5.405077 & -0.676124 \\
\hline 0 & -3.290092 & 4.898168 & -1.772458 \\
\hline C & -2.772933 & 3.707445 & -1.355979 \\
\hline C & 0.882200 & -4.798130 & 1.311382 \\
\hline $\mathrm{H}$ & -3.016702 & -1.743221 & -3.578212 \\
\hline $\mathrm{H}$ & -0.519301 & -2.823993 & 2.189651 \\
\hline $\mathrm{H}$ & 0.189421 & 0.606438 & 0.068978 \\
\hline $\mathrm{H}$ & 1.141758 & -0.807586 & -0.419046 \\
\hline $\mathrm{H}$ & 2.014971 & -1.036866 & 1.911613 \\
\hline $\mathrm{H}$ & 1.029252 & 0.327204 & 2.441837 \\
\hline $\mathrm{H}$ & 3.241366 & 2.713063 & 1.186709 \\
\hline $\mathrm{H}$ & 6.382730 & -1.486454 & -0.984298 \\
\hline $\mathrm{H}$ & 6.110961 & 3.124785 & -0.634741 \\
\hline $\mathrm{H}$ & 7.648163 & 3.221602 & -1.470233 \\
\hline $\mathrm{H}$ & -4.825529 & -2.736629 & 0.566424 \\
\hline $\mathrm{H}$ & -6.324829 & -3.159338 & -0.239321 \\
\hline $\mathrm{H}$ & -3.038586 & 1.133841 & 3.710212 \\
\hline $\mathrm{H}$ & -4.406391 & 6.361568 & -0.790399 \\
\hline $\mathrm{H}$ & -2.224706 & 3.120135 & -2.073438 \\
\hline $\mathrm{H}$ & 1.946056 & -5.042280 & 1.263612 \\
\hline $\mathrm{H}$ & 0.552686 & -4.805323 & 2.353878 \\
\hline $\mathrm{H}$ & 0.340277 & -5.576829 & 0.765161 \\
\hline \multicolumn{4}{|c|}{8} \\
\hline C & -0.865478 & 1.661248 & 0.502939 \\
\hline$N$ & -1.434651 & 2.119391 & -0.575793 \\
\hline C & -2.142884 & 3.278838 & -0.324050 \\
\hline C & -2.108612 & 3.711672 & 0.973429 \\
\hline$S$ & -1.156257 & 2.641835 & 1.932364 \\
\hline C & -0.002090 & 0.406025 & 0.547160 \\
\hline$N$ & -0.131997 & -0.237654 & -0.756868 \\
\hline C & -0.550204 & -0.521208 & 1.689524 \\
\hline C & 0.369208 & -1.466078 & -1.046965 \\
\hline O & 1.007289 & -2.130270 & -0.223465 \\
\hline C & -1.818461 & -1.254151 & 1.482678 \\
\hline 0 & 0.034110 & -0.597313 & 2.755762 \\
\hline C & 1.477250 & 0.761039 & 0.873809 \\
\hline C & 2.149997 & 1.617130 & -0.213064 \\
\hline C & 3.607490 & 1.899178 & 0.093273 \\
\hline C & 4.550090 & 0.762975 & -0.074871 \\
\hline
\end{tabular}




\begin{tabular}{lrrr}
$\mathrm{N}$ & 3.941189 & 3.078411 & 0.468766 \\
$\mathrm{~N}$ & 4.176783 & -0.458266 & -0.351261 \\
$\mathrm{C}$ & 5.243833 & -1.316510 & -0.437442 \\
$\mathrm{C}$ & 6.474023 & -0.740276 & -0.235254 \\
$\mathrm{~S}$ & 6.302886 & 0.940068 & 0.088594 \\
$\mathrm{C}$ & 5.069466 & -2.780426 & -0.709444 \\
$\mathrm{O}$ & 6.051475 & -3.504394 & -0.878958 \\
$\mathrm{~N}$ & 3.788700 & -3.221757 & -0.751004 \\
$\mathrm{C}$ & -2.878548 & 3.998937 & -1.407554 \\
$\mathrm{~N}$ & -2.757073 & 3.447683 & -2.648391 \\
$\mathrm{O}$ & -3.544937 & 5.003434 & -1.175029 \\
$\mathrm{C}$ & -2.307834 & -2.228602 & 2.307990 \\
$\mathrm{O}$ & -3.500476 & -2.640722 & 1.810284 \\
$\mathrm{C}$ & -3.696945 & -1.880467 & 0.690167 \\
$\mathrm{~N}$ & -2.725415 & -1.049670 & 0.447441 \\
$\mathrm{C}$ & -4.923054 & -2.062492 & -0.061177 \\
$\mathrm{~N}$ & -5.847362 & -3.066287 & 0.220838 \\
$\mathrm{C}$ & -6.782184 & -2.892896 & -0.654894 \\
$\mathrm{O}$ & -6.569367 & -1.853028 & -1.507892 \\
$\mathrm{C}$ & -5.373539 & -1.324432 & -1.117805 \\
$\mathrm{C}$ & 0.108000 & -1.976230 & -2.450813 \\
$\mathrm{H}$ & -2.588019 & 4.588923 & 1.383421 \\
$\mathrm{H}$ & -0.757889 & 0.218263 & -1.408413 \\
$\mathrm{H}$ & 2.011182 & -0.180170 & 1.001045 \\
$\mathrm{H}$ & 1.501858 & 1.283245 & 1.833669 \\
$\mathrm{H}$ & 1.658815 & 2.589399 & -0.306025 \\
$\mathrm{H}$ & 2.083289 & 1.100712 & -1.175858 \\
$\mathrm{H}$ & 4.945033 & 3.157791 & 0.659157 \\
$\mathrm{H}$ & 7.435434 & -1.232826 & -0.265261 \\
$\mathrm{H}$ & 3.652690 & -4.215851 & -0.862861 \\
$\mathrm{H}$ & 2.983386 & -2.648092 & -0.515571 \\
$\mathrm{H}$ & -2.126452 & 2.677145 & -2.808243 \\
$\mathrm{H}$ & -3.168484 & 3.936697 & -3.429252 \\
$\mathrm{H}$ & -1.946989 & -2.703749 & 3.205193 \\
-7.691252 & -3.458758 & -0.790730 \\
$\mathrm{H}$ & -5.006064 & -0.466595 & -1.655599 \\
$\mathrm{H}$ & 1.068919 & -2.154341 & -2.942451 \\
$\mathrm{H}$ & -411079 & -2.936325 & -2.382699 \\
\hline & & -1.290181 & -3.062367
\end{tabular}




\section{Figure S7 - DFT Calculations for Possible Aza-[4+2] Cycloaddition Mechanism}

a.

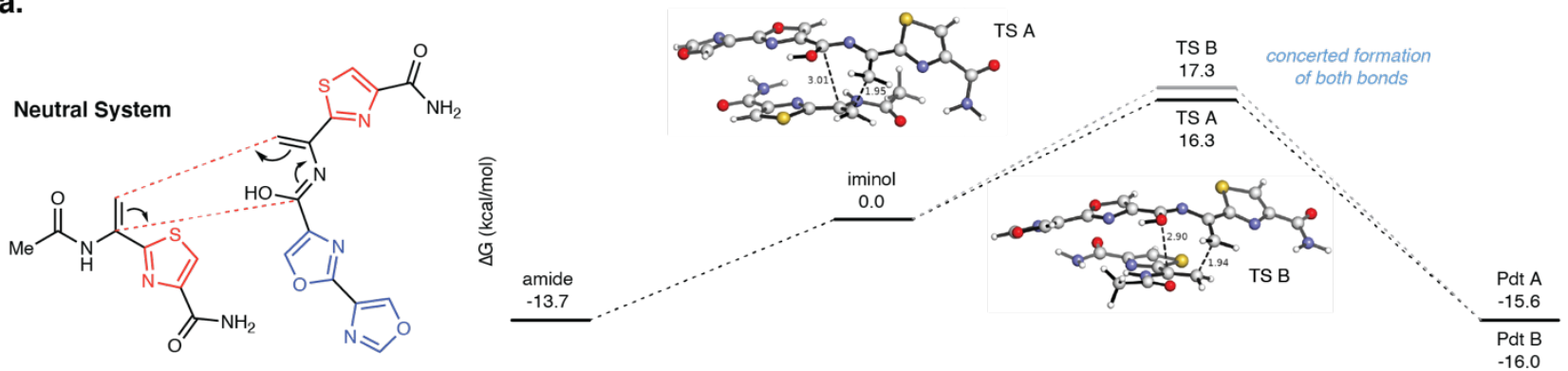

b.
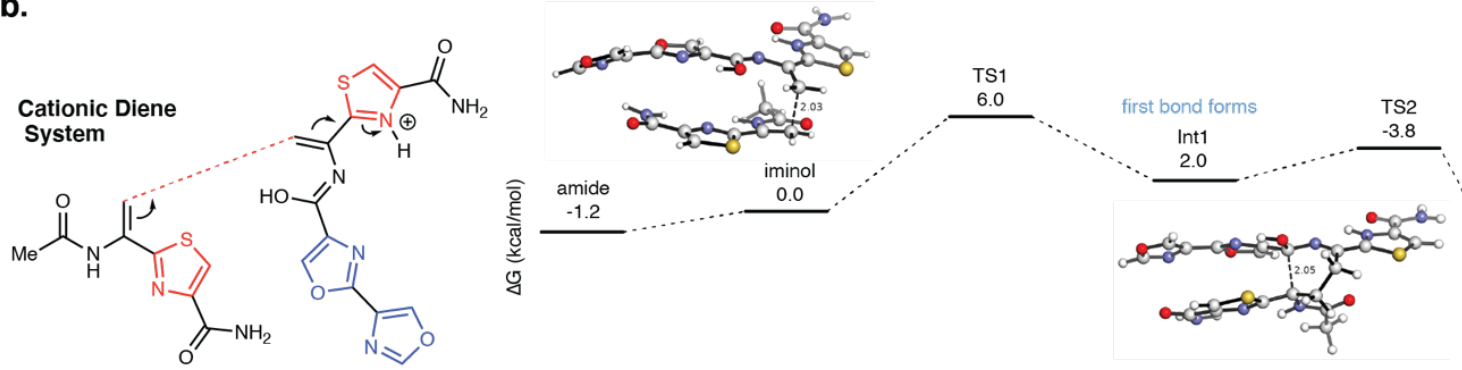

second
bond form

Pdt1

C.
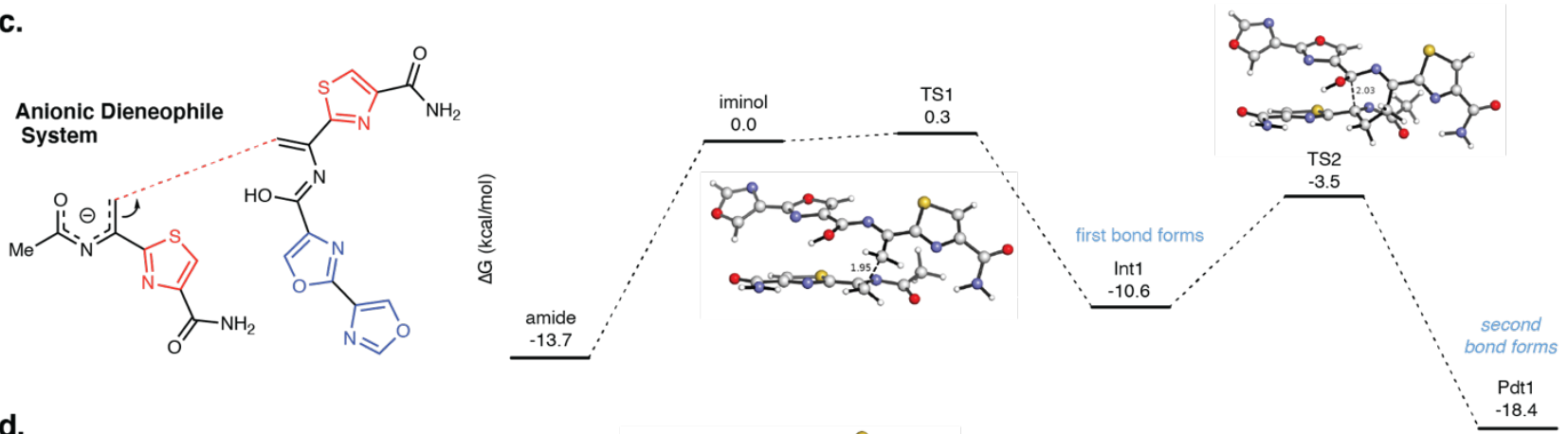

d.
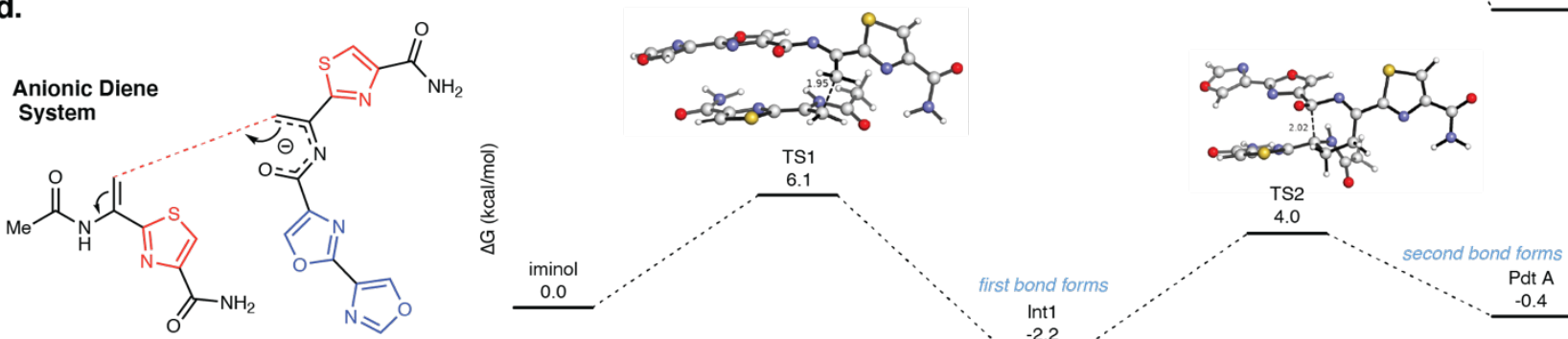

Figure S7 DFT Calculations for Possible Aza-[4+2] Cycloaddition Mechanism. Neutral, cationic and anionic manifolds are shown. Arrow pushing mechanisms for the formation of the first bonds are shown. 


\section{DFT Calculations of Aza-[4+2] Reaction}

Density functional theory (DFT) calculations were performed with Gaussian $16 .{ }^{9}$ Spartan' $16^{10}$ and CREST $^{11}$ were used for conformational searches. Molecular geometry optimizations and frequency calculations were performed using the M062X functional, ${ }^{12}$ augmented with Grimme's D3 empirical dispersion term, ${ }^{13}$ and the $6-31 G(d)$ basis set. Frequency calculations confirmed the optimized structures as minima (zero imaginary frequencies) or transition state structures (one imaginary frequency) on the potential energy surface. Single point energies were calculated using the M062X-D3 functional and 6-311+G(d,p) basis set. A quasi-harmonic correction was applied using the GoodVibes program. ${ }^{14} 3 \mathrm{D}$ renderings of optimized structures were generated using PyMol 2.3.2. ${ }^{15}$ GaussView 6.0.16 ${ }^{16}$ was used to generate initial structures.

Geometry of bisthiazole and bisoxazole:

\footnotetext{
${ }^{9}$ Gaussian 16, Revision C.01, Frisch, M. J.; Trucks, G. W.; Schlegel, H. B.; Scuseria, G. E.; Robb, M. A.; Cheeseman, J. R.; Scalmani, G.; Barone, V.; Petersson, G. A.; Nakatsuji, H.; Li, X.; Caricato, M.; Marenich, A. V.; Bloino, J.; Janesko, B. G.; Gomperts, R.; Mennucci, B.; Hratchian, H. P.; Ortiz, J. V.; Izmaylov, A. F.; Sonnenberg, J. L.; Williams-Young, D.; Ding, F.; Lipparini, F.; Egidi, F.; Goings, J.; Peng, B.; Petrone, A.; Henderson, T.; Ranasinghe, D.; Zakrzewski, V. G.; Gao, J.; Rega, N.; Zheng, G.; Liang, W.; Hada, M.; Ehara, M.; Toyota, K.; Fukuda, R.; Hasegawa, J.; Ishida, M.; Nakajima, T.; Honda, Y.; Kitao, O.; Nakai, H.; Vreven, T.; Throssell, K.; Montgomery, J. A., Jr.; Peralta, J. E.; Ogliaro, F.; Bearpark, M. J.; Heyd, J. J.; Brothers, E. N.; Kudin, K. N.; Staroverov, V. N.; Keith, T. A.; Kobayashi, R.; Normand, J.; Raghavachari, K.; Rendell, A. P.; Burant, J. C.; lyengar, S. S.; Tomasi, J.; Cossi, M.; Millam, J. M.; Klene, M.; Adamo, C.; Cammi, R.; Ochterski, J. W.; Martin, R. L.; Morokuma, K.; Farkas, O.; Foresman, J. B.; Fox, D. J. Gaussian, Inc., Wallingford CT, 2016

${ }^{10}$ Spartan'16. Wavefunction, Inc. Irvine, CA

${ }^{11}$ Pracht, P.; Bohle, F.; Grimme, S. Phys. Chem. Chem. Phys. 2020, 22, 7169

${ }^{12}$ Zhao, Y.; Truhlar, D. G. Theor. Chem. Acc. 2008, 120, 215

${ }_{13}$ Grimme, S.; Antony, J.; Ehrlich, S.; Krieg, H. J. Chem. Phys. 2010, 132, 154104

${ }_{11}^{14}$ Paton, R. S.; Rodríguez-Guerra, J.; Chen, J.; Funes, I; GoodVibes: version 3.0.0; Zenodo, 2019

${ }^{15}$ The PyMOL Molecular Graphics System, Version 2. Schrödinger, LLC.

${ }^{16}$ GaussView, Version 6, Dennington, Roy; Keith, Todd A.; Millam, John M. Semichem Inc., Shawnee Mission, KS, 2016
} 


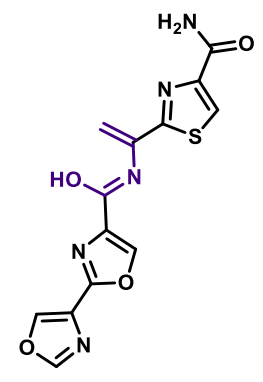

$\Delta \Delta \mathrm{G}=0 \mathrm{kcal} / \mathrm{mol}$

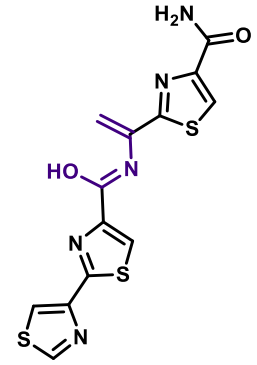

$\Delta \Delta \mathrm{G}=0 \mathrm{kcal} / \mathrm{mol}$

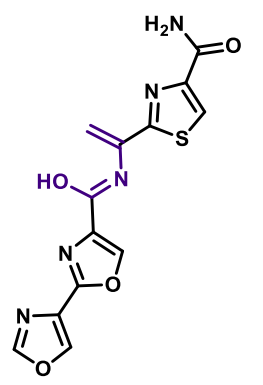

$\Delta \Delta \mathrm{G}=0.4 \mathrm{kcal} / \mathrm{mol}$

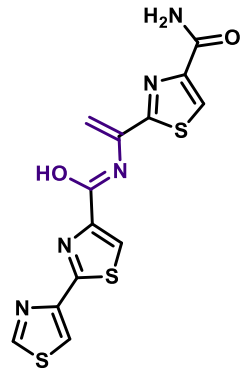

$\Delta \Delta \mathrm{G}=3.2 \mathrm{kcal} / \mathrm{mol}$

Tautomerization energy differences for bisthiazole and bisoxazole substrates:

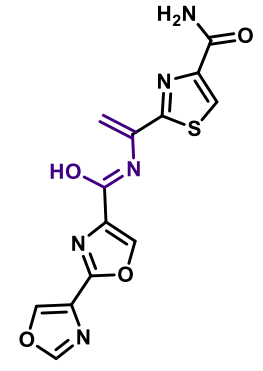

$\Delta \Delta \mathrm{G}=0 \mathrm{kcal} / \mathrm{mol}$



$\Delta \Delta \mathrm{G}=0 \mathrm{kcal} / \mathrm{mol}$

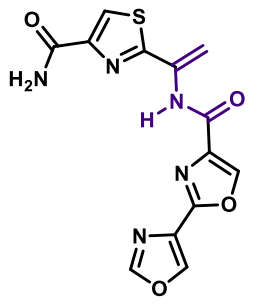

$\Delta \Delta \mathrm{G}=13.7 \mathrm{kcal} / \mathrm{mol}$

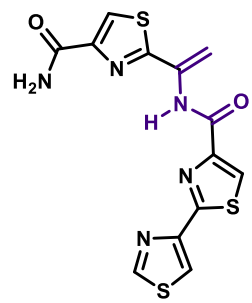

$\Delta \Delta \mathrm{G}=13.2 \mathrm{kcal} / \mathrm{mol}$ 


\section{Summary of Energies}

\begin{tabular}{|c|c|c|c|c|c|}
\hline Structure & $\begin{array}{c}\text { E_SPC } \\
\text { (au) }\end{array}$ & $\begin{array}{c}\text { qh-H_SPC } \\
\text { (au) }\end{array}$ & $\begin{array}{c}\text { T.qh-S } \\
\text { (au) }\end{array}$ & $\begin{array}{c}\text { qh-G(T)_SPC } \\
\text { (au) }\end{array}$ & $\begin{array}{c}\text { qh-G(T)_SPC } \\
\text { (kcal/mol) }\end{array}$ \\
\hline \multicolumn{6}{|l|}{ Diene and dienophile } \\
\hline 1. dienophile(0) & -1023.11 & -1022.93 & 0.05584 & -1022.98 & -641929.9 \\
\hline 2. dienophile(-1) & -1022.56 & -1022.39 & 0.05477 & -1022.45 & -641594.0 \\
\hline 3. diene( 0 , amide) & -1473.53 & -1473.29 & 0.06801 & -1473.36 & -924545.8 \\
\hline 4. diene $(0$, iminol) & -1473.51 & -1473.27 & 0.06838 & -1473.34 & -924532.1 \\
\hline 5. diene( 0 , iminol, cis bisoxazoles) & -1473.51 & -1473.27 & 0.06810 & -1473.34 & -924531.7 \\
\hline 6. diene(+1, amide) & -1473.88 & -1473.63 & 0.06849 & -1473.70 & -924757.6 \\
\hline 7. diene(+1, iminol) & -1473.88 & -1473.63 & 0.06823 & -1473.69 & -924756.4 \\
\hline 8. diene(-1) & -1472.99 & -1472.76 & 0.06802 & -1472.83 & -924213.1 \\
\hline \multicolumn{6}{|l|}{ Neutral } \\
\hline 1. TS1a (exo) & -2496.62 & -2496.20 & 0.09235 & -2496.29 & -1566443.0 \\
\hline 2. TS1b (endo) & -2496.62 & -2496.19 & 0.09435 & -2496.29 & -1566442.3 \\
\hline 3. Pdt1a (exo) & -2496.68 & -2496.25 & 0.09433 & -2496.34 & -1566477.4 \\
\hline 4. Pdt1b (endo) & -2496.68 & -2496.25 & 0.09549 & -2496.35 & -1566480.7 \\
\hline \multicolumn{6}{|l|}{ [4+2] with protonated diene } \\
\hline 1. TS1a (exo) & -2497.01 & -2496.57 & 0.09349 & -2496.67 & -1566680.4 \\
\hline 2. Int1a (exo) & -2497.02 & -2496.58 & 0.09387 & -2496.67 & -1566684.3 \\
\hline 3. TS2a (exo) & -2497.02 & -2496.58 & 0.09198 & -2496.67 & -1566682.5 \\
\hline 4. Pdt1a (exo) & -2497.04 & -2496.60 & 0.09222 & -2496.69 & -1566696.4 \\
\hline \multicolumn{6}{|l|}{ [4+2] with deprotonated dienophile } \\
\hline 1. TS1a (exo) & -2496.10 & -2495.69 & 0.09175 & -2495.78 & -1566125.7 \\
\hline 2. Int1a (exo) & -2496.12 & -2495.71 & 0.09301 & -2495.80 & -1566136.7 \\
\hline 3. TS2a (exo) & -2496.11 & -2495.70 & 0.08979 & -2495.79 & -1566129.5 \\
\hline 4. Pdt1a (exo) & -2496.14 & -2495.72 & 0.09210 & -2495.81 & -1566144.4 \\
\hline \multicolumn{6}{|l|}{ [4+2] with deprotonated diene } \\
\hline 1. TS1a (exo) & -2496.12 & -2495.71 & 0.09198 & -2495.80 & -1566136.9 \\
\hline 2. Int1a (exo) & -2496.14 & -2495.72 & 0.09232 & -2495.81 & -1566145.2 \\
\hline 3. TS2a (exo) & -2496.12 & -2495.71 & 0.09394 & -2495.80 & -1566139.0 \\
\hline 4. Pdt1a (exo) & -2496.13 & -2495.72 & 0.09427 & -2495.81 & -1566143.4 \\
\hline \multicolumn{6}{|l|}{ Bisthiazole } \\
\hline 1. Diene (iminol) & -2119.46 & -2119.23 & 0.07016 & -2119.30 & -1329878.1 \\
\hline 2. Diene (amide) & -2119.48 & -2119.25 & 0.06937 & -2119.32 & -1329891.3 \\
\hline 3. Diene (iminol, cis bisoxazole) & -2119.46 & -2119.22 & 0.07104 & -2119.29 & -1329874.9 \\
\hline 4. TS1a (exo) & -3142.58 & -3142.15 & 0.09472 & -3142.25 & -1971789.8 \\
\hline 5. TS1b (endo) & -3142.57 & -3142.15 & 0.09679 & -3142.25 & -1971789.5 \\
\hline
\end{tabular}




\begin{tabular}{|l|l|l|l|l|l|}
\hline 6. Pdt (exo) & -3142.63 & -3142.21 & 0.09577 & -3142.30 & -1971824.6 \\
\hline \multicolumn{7}{|l|}{} \\
\hline Second step - loss of water \\
\hline 1. Oxazole product & -2420.57 & -2420.16 & 0.09199 & -2420.25 & -1518729.9 \\
\hline 2. Thiazole product & -3066.53 & -3066.12 & 0.09399 & -3066.22 & -1924078.9 \\
\hline
\end{tabular}

\section{Diene and dienophile}

1 Dienophile (0)

$\begin{array}{lrrr}\text { C } & 0.045058 & -0.788197 & -0.001431 \\ \text { N } & 0.714382 & 0.329029 & -0.002888 \\ \text { C } & 2.069472 & 0.095176 & -0.000319 \\ \text { C } & 2.438564 & -1.214158 & 0.002643 \\ \text { S } & 1.046190 & -2.215916 & 0.001552 \\ \text { C } & -1.431473 & -0.838730 & -0.003587 \\ \text { N } & -1.981560 & 0.448583 & -0.026948 \\ \text { C } & -3.317322 & 0.773073 & -0.016187 \\ \text { O } & -4.208270 & -0.052274 & -0.006937 \\ \text { C } & -2.110094 & -1.993338 & 0.014098 \\ \text { C } & 3.066632 & 1.208843 & 0.000243 \\ \text { N } & 2.514048 & 2.446544 & -0.000438 \\ \text { O } & 4.263790 & 0.988114 & 0.001011 \\ \text { C } & -3.585746 & 2.265330 & 0.019346 \\ \text { H } & 3.446528 & -1.603087 & 0.004988 \\ \text { H } & -1.298097 & 1.195174 & -0.032374 \\ \text { H } & -1.566416 & -2.931777 & 0.033014 \\ \text { H } & -3.188544 & -2.016120 & 0.010659 \\ \text { H } & 1.513116 & 2.564388 & 0.004365 \\ \text { H } & 3.124983 & 3.248873 & 0.003959 \\ \text { H } & -4.584680 & 2.444563 & -0.377002 \\ \text { H } & -3.555994 & 2.614263 & 1.056301 \\ \text { H } & -2.852733 & 2.834576 & -0.558255 \\ \text { 2 Dienophile }(-1) & & \\ \text { C } & -0.043586 & 0.135844 & -0.002781 \\ \text { N } & -1.209053 & 0.715113 & -0.001656 \\ \text { C } & -2.223763 & -0.214581 & -0.002852 \\ \text { C } & -1.836060 & -1.520276 & -0.004304 \\ \text { S } & -0.118162 & -1.621136 & -0.005343 \\ \text { C } & 1.307786 & 0.748986 & -0.000745 \\ \text { N } & 2.267489 & -0.237932 & -0.000820 \\ \text { C } & 3.562993 & 0.104867 & 0.002452 \\ \text { O } & 4.077942 & 1.236945 & 0.005809 \\ \text { C } & 1.371740 & 2.102177 & 0.001061 \\ \text { C } & -3.641781 & 0.234824 & 0.002897\end{array}$




\begin{tabular}{|c|c|c|c|}
\hline $\mathrm{N}$ & -3.769273 & 1.588551 & -0.020499 \\
\hline 0 & -4.592773 & -0.534598 & 0.020842 \\
\hline C & 4.509811 & -1.099970 & 0.002302 \\
\hline $\mathrm{H}$ & -2.490774 & -2.379818 & -0.004188 \\
\hline $\mathrm{H}$ & 0.448142 & 2.672365 & 0.000448 \\
\hline $\mathrm{H}$ & 2.325916 & 2.605610 & 0.002830 \\
\hline $\mathrm{H}$ & -2.935122 & 2.158436 & 0.007334 \\
\hline $\mathrm{H}$ & -4.689960 & 1.992790 & 0.031244 \\
\hline $\mathrm{H}$ & 5.162701 & -1.045590 & -0.875729 \\
\hline $\mathrm{H}$ & 5.156831 & -1.050372 & 0.884968 \\
\hline $\mathrm{H}$ & 3.964521 & -2.045365 & -0.001977 \\
\hline \multicolumn{4}{|c|}{3 Diene $(0$, amide $)$} \\
\hline C & 0.273985 & -2.585300 & 0.051509 \\
\hline C & 1.625494 & -1.973807 & 0.057049 \\
\hline $\mathrm{O}$ & 0.117306 & -3.792696 & 0.096668 \\
\hline C & -2.687547 & -3.097161 & -0.016836 \\
\hline C & -2.096148 & -1.895579 & -0.021897 \\
\hline C & -2.855183 & -0.629157 & -0.035907 \\
\hline $\mathrm{N}$ & -0.719878 & -1.652607 & -0.009077 \\
\hline $\mathrm{N}$ & -2.277872 & 0.531303 & 0.076721 \\
\hline C & -3.197094 & 1.550768 & 0.032948 \\
\hline C & -4.493294 & 1.165490 & -0.118380 \\
\hline$S$ & -4.587267 & -0.545997 & -0.216755 \\
\hline C & -2.780864 & 2.980339 & 0.162245 \\
\hline $\mathrm{O}$ & -3.591021 & 3.887397 & 0.113389 \\
\hline $\mathrm{N}$ & -1.444754 & 3.149147 & 0.329446 \\
\hline C & 2.814312 & -2.620307 & 0.134796 \\
\hline 0 & 3.792349 & -1.683395 & 0.105672 \\
\hline C & 3.145772 & -0.503025 & 0.010198 \\
\hline$N$ & 1.854371 & -0.609787 & -0.019915 \\
\hline C & 3.933834 & 0.713640 & -0.060379 \\
\hline$N$ & 5.313586 & 0.735197 & 0.079106 \\
\hline C & 5.614869 & 1.980840 & -0.045241 \\
\hline 0 & 4.561039 & 2.797971 & -0.256566 \\
\hline C & 3.483574 & 1.977873 & -0.266699 \\
\hline $\mathrm{H}$ & -3.770380 & -3.159529 & -0.013832 \\
\hline $\mathrm{H}$ & -2.112210 & -4.010301 & -0.007056 \\
\hline $\mathrm{H}$ & -5.360225 & 1.807947 & -0.173049 \\
\hline $\mathrm{H}$ & -1.099550 & 4.081174 & 0.500803 \\
\hline $\mathrm{H}$ & -0.839735 & 2.349477 & 0.443513 \\
\hline $\mathrm{H}$ & 3.106871 & -3.654247 & 0.210578 \\
\hline $\mathrm{H}$ & 6.589281 & 2.443613 & -0.001698 \\
\hline $\mathrm{H}$ & 2.515115 & 2.419642 & -0.432480 \\
\hline $\mathrm{H}$ & -0.438706 & -0.676495 & -0.026407 \\
\hline
\end{tabular}




\begin{tabular}{|c|c|c|c|}
\hline \multicolumn{4}{|c|}{4 Diene $(0$, iminol) } \\
\hline \multicolumn{4}{|c|}{1.032092} \\
\hline C & -1.821956 & 0.178043 & -0.006973 \\
\hline $\mathrm{O}$ & -0.891219 & 2.348715 & 0.005929 \\
\hline C & 1.949233 & 2.536677 & -0.016247 \\
\hline C & 1.736558 & 1.211180 & -0.011014 \\
\hline C & 2.892874 & 0.288322 & -0.004951 \\
\hline N & 0.527743 & 0.500823 & -0.012526 \\
\hline N & 4.144378 & 0.636663 & -0.000916 \\
\hline C & 4.959478 & -0.468392 & 0.004293 \\
\hline C & 4.324889 & -1.674157 & 0.004401 \\
\hline$S$ & 2.626449 & -1.439018 & -0.002388 \\
\hline C & 6.447186 & -0.332772 & 0.009733 \\
\hline 0 & 7.181618 & -1.305288 & 0.014411 \\
\hline $\mathrm{N}$ & 6.876038 & 0.953342 & 0.008971 \\
\hline C & -1.943256 & -1.172429 & -0.016989 \\
\hline $\mathrm{O}$ & -3.267953 & -1.458921 & -0.014084 \\
\hline C & -3.893491 & -0.265959 & -0.002361 \\
\hline N & -3.083426 & 0.747631 & 0.002347 \\
\hline C & -5.343795 & -0.244342 & 0.003583 \\
\hline $\mathrm{N}$ & -6.117509 & -1.395260 & -0.002473 \\
\hline C & -7.326032 & -0.951556 & 0.005927 \\
\hline $\mathrm{O}$ & -7.432522 & 0.394504 & 0.017119 \\
\hline C & -6.156019 & 0.844088 & 0.015562 \\
\hline $\mathrm{H}$ & -1.862020 & 2.457387 & 0.011606 \\
\hline$H$ & 2.973035 & 2.892717 & -0.016079 \\
\hline $\mathrm{H}$ & 1.143563 & 3.255183 & -0.021294 \\
\hline $\mathrm{H}$ & 4.793361 & -2.647613 & 0.008028 \\
\hline $\mathrm{H}$ & 7.867575 & 1.134837 & 0.012672 \\
\hline $\mathrm{H}$ & 6.209926 & 1.711189 & 0.005055 \\
\hline$H$ & -1.247469 & -1.994704 & -0.026006 \\
\hline $\mathrm{H}$ & -8.247780 & -1.513555 & 0.005155 \\
\hline $\mathrm{H}$ & -5.996924 & 1.909610 & 0.023465 \\
\hline \multicolumn{4}{|c|}{5 Diene $(+1$, amide $)$} \\
\hline C & -0.341464 & -2.331820 & 0.441661 \\
\hline C & -1.689971 & -1.745744 & 0.474766 \\
\hline $\mathrm{O}$ & -0.037339 & -3.387327 & 0.947261 \\
\hline C & 2.369676 & -3.110574 & -0.594498 \\
\hline C & 1.896905 & -1.861563 & -0.463891 \\
\hline C & 2.815118 & -0.725641 & -0.408533 \\
\hline N & 0.563762 & -1.506783 & -0.232676 \\
\hline $\mathrm{N}$ & 2.512076 & 0.419615 & 0.182408 \\
\hline C & 3.489735 & 1.392206 & 0.164733 \\
\hline & 4.593859 & 0.966817 & -0.493302 \\
\hline
\end{tabular}




\begin{tabular}{|c|c|c|c|}
\hline S & 4.381831 & -0.641988 & -1.093451 \\
\hline C & 3.077712 & 2.666161 & 0.860008 \\
\hline $\mathrm{O}$ & 1.939295 & 2.713072 & 1.285716 \\
\hline$N$ & 3.992234 & 3.644044 & 0.944419 \\
\hline C & -2.809560 & -2.252861 & 1.049736 \\
\hline 0 & -3.806450 & -1.373984 & 0.823031 \\
\hline C & -3.252511 & -0.364991 & 0.115461 \\
\hline$N$ & -1.987083 & -0.531124 & -0.122210 \\
\hline C & -4.107555 & 0.737372 & -0.277764 \\
\hline$N$ & -5.451393 & 0.792238 & 0.055219 \\
\hline C & -5.851232 & 1.899369 & -0.465917 \\
\hline $\mathrm{O}$ & -4.890781 & 2.590836 & -1.119184 \\
\hline C & -3.774517 & 1.841691 & -0.996027 \\
\hline $\mathrm{H}$ & 3.437199 & -3.300213 & -0.641082 \\
\hline $\mathrm{H}$ & 1.700430 & -3.960504 & -0.591213 \\
\hline $\mathrm{H}$ & 5.515533 & 1.498432 & -0.685502 \\
\hline $\mathrm{H}$ & 3.728300 & 4.496370 & 1.422790 \\
\hline $\mathrm{H}$ & 4.948581 & 3.546566 & 0.639258 \\
\hline $\mathrm{H}$ & -3.038769 & -3.147315 & 1.606120 \\
\hline $\mathrm{H}$ & -6.838916 & 2.334946 & -0.446279 \\
\hline $\mathrm{H}$ & -2.870576 & 2.209826 & -1.452113 \\
\hline $\mathrm{H}$ & 1.628057 & 0.603871 & 0.668807 \\
\hline $\mathrm{H}$ & 0.138702 & -0.739409 & -0.748882 \\
\hline \multicolumn{4}{|c|}{6 Diene $(+1$, iminol) } \\
\hline C & -0.447951 & -1.294972 & 0.000248 \\
\hline C & -1.545437 & -0.329708 & 0.000425 \\
\hline $\mathrm{O}$ & -0.830698 & -2.566658 & -0.000364 \\
\hline C & 1.916096 & -3.140092 & 0.000677 \\
\hline C & 1.852045 & -1.795079 & 0.000425 \\
\hline C & 3.106270 & -1.023551 & 0.000068 \\
\hline$N$ & 0.775947 & -0.908000 & 0.000642 \\
\hline$N$ & 3.083876 & 0.294934 & 0.000097 \\
\hline C & 4.301871 & 0.934970 & -0.000230 \\
\hline C & 5.320728 & 0.042246 & -0.000520 \\
\hline$S$ & 4.725523 & -1.583629 & -0.000417 \\
\hline C & 4.195951 & 2.438567 & -0.000116 \\
\hline $\mathrm{O}$ & 3.076984 & 2.915372 & 0.000475 \\
\hline C & -1.563024 & 1.027951 & 0.001025 \\
\hline $\mathrm{O}$ & -2.856695 & 1.407929 & 0.000855 \\
\hline C & -3.578808 & 0.265708 & 0.000173 \\
\hline$N$ & -2.844547 & -0.804532 & -0.000096 \\
\hline C & -5.022895 & 0.371183 & -0.000151 \\
\hline$N$ & -5.679771 & 1.591018 & 0.000091 \\
\hline C & -6.925603 & 1.266259 & -0.000339 \\
\hline
\end{tabular}




\begin{tabular}{|c|c|c|c|}
\hline 0 & -7.157539 & -0.065443 & -0.000798 \\
\hline C & -5.935636 & -0.636327 & -0.000726 \\
\hline $\mathrm{H}$ & -1.812159 & -2.589308 & -0.000657 \\
\hline $\mathrm{H}$ & 2.878248 & -3.644596 & 0.000586 \\
\hline $\mathrm{H}$ & 1.031358 & -3.758819 & 0.001017 \\
\hline $\mathrm{H}$ & 6.386080 & 0.225860 & -0.000764 \\
\hline $\mathrm{H}$ & -0.816111 & 1.805060 & 0.001581 \\
\hline $\mathrm{H}$ & -7.790425 & 1.912524 & -0.000330 \\
\hline $\mathrm{H}$ & -5.883145 & -1.712798 & -0.001062 \\
\hline $\mathrm{H}$ & 2.192827 & 0.802958 & 0.000367 \\
\hline $\mathrm{N}$ & 5.344781 & 3.133929 & -0.000629 \\
\hline $\mathrm{H}$ & 5.285743 & 4.144167 & -0.000435 \\
\hline $\mathrm{H}$ & 6.259171 & 2.709038 & -0.001459 \\
\hline \multicolumn{4}{|c|}{7 Diene $(-1)$} \\
\hline C & -0.620762 & 1.364650 & -0.000152 \\
\hline C & -1.809988 & 0.435349 & -0.000210 \\
\hline 0 & -0.824581 & 2.585369 & 0.000248 \\
\hline C & 2.036815 & 2.650582 & -0.000038 \\
\hline C & 1.723785 & 1.333392 & -0.000211 \\
\hline C & 2.847875 & 0.365188 & -0.000166 \\
\hline $\mathrm{N}$ & 0.520758 & 0.666053 & -0.000254 \\
\hline$N$ & 4.127101 & 0.601449 & 0.000056 \\
\hline C & 4.847816 & -0.570556 & 0.000085 \\
\hline C & 4.117956 & -1.720225 & -0.000073 \\
\hline$S$ & 2.439527 & -1.344714 & -0.000288 \\
\hline C & 6.335695 & -0.529901 & 0.000322 \\
\hline 0 & 7.034169 & -1.533661 & 0.000430 \\
\hline $\mathrm{N}$ & 6.832116 & 0.735175 & 0.000278 \\
\hline C & -1.807944 & -0.923508 & -0.000471 \\
\hline 0 & -3.100276 & -1.362241 & -0.000369 \\
\hline C & -3.826398 & -0.225392 & -0.000096 \\
\hline$N$ & -3.130386 & 0.865356 & -0.000008 \\
\hline C & -5.276451 & -0.318388 & 0.000074 \\
\hline$N$ & -5.987258 & -1.514266 & -0.000102 \\
\hline C & -7.219738 & -1.141302 & 0.000131 \\
\hline $\mathrm{O}$ & -7.412367 & 0.192734 & 0.000457 \\
\hline C & -6.154645 & 0.716468 & 0.000413 \\
\hline $\mathrm{H}$ & 3.081852 & 2.942151 & 0.000114 \\
\hline $\mathrm{H}$ & 1.260737 & 3.400329 & -0.000045 \\
\hline $\mathrm{H}$ & 4.510533 & -2.726732 & -0.000060 \\
\hline $\mathrm{H}$ & 7.830057 & 0.868990 & 0.000637 \\
\hline $\mathrm{H}$ & 6.190273 & 1.515541 & 0.000361 \\
\hline $\mathrm{H}$ & -1.027580 & -1.665287 & -0.000699 \\
\hline $\mathrm{H}$ & -8.105112 & -1.759818 & 0.000102 \\
\hline
\end{tabular}


$\begin{array}{llll}\text { H } & -6.049152 & 1.788134 & 0.000635\end{array}$

\section{Neutral}

1 TS1a (exo)

\begin{tabular}{|c|c|c|c|}
\hline C & -0.828625 & 1.777887 & 0.016646 \\
\hline$N$ & -1.531855 & 1.203951 & 0.967277 \\
\hline C & -2.869596 & 1.473451 & 0.813640 \\
\hline C & -3.211541 & 2.247098 & -0.252252 \\
\hline$S$ & -1.803297 & 2.673660 & -1.138774 \\
\hline C & 0.612972 & 1.749078 & -0.051362 \\
\hline$N$ & 1.230866 & 1.061715 & 0.981116 \\
\hline C & -0.110749 & -0.679695 & -1.680075 \\
\hline C & 2.543148 & 1.183920 & 1.402325 \\
\hline O & 3.308425 & 2.027024 & 0.970669 \\
\hline C & -1.246103 & -1.285522 & -0.998129 \\
\hline $\mathrm{O}$ & -0.422890 & 0.159125 & -2.686600 \\
\hline C & 1.369867 & 2.311307 & -1.087225 \\
\hline C & 2.224569 & 0.965682 & -2.207299 \\
\hline C & 2.201208 & -0.288118 & -1.573477 \\
\hline C & 3.398518 & -0.796912 & -0.914132 \\
\hline$N$ & 1.076200 & -0.993757 & -1.287548 \\
\hline$N$ & 4.448555 & -0.082835 & -0.631400 \\
\hline C & 5.369456 & -0.818183 & 0.068895 \\
\hline C & 5.051806 & -2.126750 & 0.280912 \\
\hline$S$ & 3.494101 & -2.464337 & -0.370409 \\
\hline C & 6.554630 & -0.149069 & 0.690539 \\
\hline $\mathrm{O}$ & 7.521849 & -0.777333 & 1.085217 \\
\hline$N$ & 6.397760 & 1.192851 & 0.809811 \\
\hline C & -3.907225 & 0.861251 & 1.698651 \\
\hline$N$ & -3.418652 & -0.040539 & 2.584270 \\
\hline O & -5.090936 & 1.136182 & 1.578199 \\
\hline C & -1.266561 & -2.107424 & 0.083677 \\
\hline $\mathrm{O}$ & -2.563050 & -2.261269 & 0.448539 \\
\hline C & -3.270907 & -1.504453 & -0.415896 \\
\hline$N$ & -2.539014 & -0.906726 & -1.306791 \\
\hline C & -4.698079 & -1.376449 & -0.207582 \\
\hline$N$ & -5.349820 & -1.898447 & 0.899787 \\
\hline C & -6.552859 & -1.453508 & 0.779375 \\
\hline $\mathrm{O}$ & -6.767862 & -0.696257 & -0.314703 \\
\hline C & -5.572950 & -0.640646 & -0.939823 \\
\hline C & 2.954476 & 0.148712 & 2.422294 \\
\hline $\mathrm{H}$ & -4.207627 & 2.548815 & -0.540892 \\
\hline $\mathrm{H}$ & 0.614321 & 0.463408 & 1.521143 \\
\hline
\end{tabular}




\begin{tabular}{|c|c|c|c|}
\hline $\mathrm{H}$ & -1.396781 & 0.246103 & -2.707983 \\
\hline $\mathrm{H}$ & 0.808654 & 2.895249 & -1.812399 \\
\hline $\mathrm{H}$ & 2.320998 & 2.739064 & -0.797912 \\
\hline $\mathrm{H}$ & 3.214787 & 1.391701 & -2.335500 \\
\hline $\mathrm{H}$ & 1.541488 & 1.111276 & -3.034041 \\
\hline $\mathrm{H}$ & 5.643898 & -2.860401 & 0.808603 \\
\hline $\mathrm{H}$ & 7.108929 & 1.705901 & 1.308856 \\
\hline $\mathrm{H}$ & 5.500766 & 1.626673 & 0.615115 \\
\hline $\mathrm{H}$ & -2.448884 & -0.315028 & 2.523043 \\
\hline $\mathrm{H}$ & -4.080271 & -0.669367 & 3.018011 \\
\hline $\mathrm{H}$ & -0.513518 & -2.631066 & 0.648777 \\
\hline $\mathrm{H}$ & -7.395890 & -1.612730 & 1.434119 \\
\hline $\mathrm{H}$ & -5.501423 & -0.059863 & -1.844454 \\
\hline $\mathrm{H}$ & 2.271519 & 0.134077 & 3.277511 \\
\hline $\mathrm{H}$ & 2.946520 & -0.844436 & 1.958545 \\
\hline $\mathrm{H}$ & 3.964350 & 0.378239 & 2.761945 \\
\hline \multicolumn{4}{|c|}{2 TS1b (endo) } \\
\hline C & -0.045816 & -0.128131 & 1.521660 \\
\hline N & -1.221534 & -0.713986 & 1.479058 \\
\hline C & -1.086442 & -2.079411 & 1.513966 \\
\hline C & 0.189529 & -2.551509 & 1.580083 \\
\hline$S$ & 1.302412 & -1.239927 & 1.618516 \\
\hline C & 0.132942 & 1.303556 & 1.457480 \\
\hline N & -1.067616 & 1.999300 & 1.333746 \\
\hline C & -0.087734 & 1.050069 & -1.425264 \\
\hline C & -1.241944 & 3.358738 & 1.244508 \\
\hline O & -0.330753 & 4.163784 & 1.304425 \\
\hline C & -1.284542 & 0.223180 & -1.482570 \\
\hline O & -0.311624 & 2.374896 & -1.426700 \\
\hline C & 1.400169 & 1.896884 & 1.529020 \\
\hline C & 2.208430 & 2.292402 & -0.194910 \\
\hline C & 2.197374 & 1.095543 & -0.927461 \\
\hline C & 3.386149 & 0.248473 & -0.939794 \\
\hline N & 1.071375 & 0.484672 & -1.375400 \\
\hline$N$ & 4.521387 & 0.535503 & -0.364097 \\
\hline C & 5.428963 & -0.478161 & -0.547063 \\
\hline C & 4.994393 & -1.543729 & -1.276537 \\
\hline$S$ & 3.365992 & -1.297335 & -1.763716 \\
\hline C & 6.807882 & -0.395592 & 0.021896 \\
\hline O & 7.621406 & -1.289756 & -0.131198 \\
\hline N & 7.044619 & 0.747982 & 0.711150 \\
\hline C & -2.278833 & -2.977039 & 1.397199 \\
\hline$N$ & -3.470705 & -2.329615 & 1.494901 \\
\hline O & -2.153816 & -4.176873 & 1.233036 \\
\hline C & -1.418076 & -1.129045 & -1.508550 \\
\hline
\end{tabular}




\begin{tabular}{|c|c|c|c|}
\hline O & -2.733226 & -1.409293 & -1.353872 \\
\hline C & -3.341684 & -0.217891 & -1.212829 \\
\hline$N$ & -2.531953 & 0.795320 & -1.284256 \\
\hline C & -4.780126 & -0.184469 & -1.015722 \\
\hline$N$ & -5.521696 & -1.283734 & -0.602445 \\
\hline C & -6.727604 & -0.833796 & -0.533200 \\
\hline $\mathrm{O}$ & -6.860989 & 0.466820 & -0.860749 \\
\hline C & -5.609524 & 0.880050 & -1.170401 \\
\hline C & -2.693209 & 3.774198 & 1.090504 \\
\hline $\mathrm{H}$ & 0.498577 & -3.586147 & 1.605073 \\
\hline $\mathrm{H}$ & -1.883893 & 1.400246 & 1.259969 \\
\hline $\mathrm{H}$ & -1.277454 & 2.514800 & -1.415064 \\
\hline $\mathrm{H}$ & 1.431629 & 2.926633 & 1.861955 \\
\hline $\mathrm{H}$ & 2.189538 & 1.260230 & 1.921348 \\
\hline $\mathrm{H}$ & 3.186739 & 2.620219 & 0.144454 \\
\hline $\mathrm{H}$ & 1.518157 & 3.081418 & -0.460129 \\
\hline $\mathrm{H}$ & 5.565285 & -2.424526 & -1.532142 \\
\hline $\mathrm{H}$ & 7.961092 & 0.896787 & 1.103849 \\
\hline $\mathrm{H}$ & 6.334020 & 1.461708 & 0.769936 \\
\hline $\mathrm{H}$ & -3.465654 & -1.320086 & 1.461085 \\
\hline $\mathrm{H}$ & -4.289307 & -2.798494 & 1.131670 \\
\hline $\mathrm{H}$ & -0.731614 & -1.956029 & -1.592789 \\
\hline $\mathrm{H}$ & -7.625431 & -1.361576 & -0.248401 \\
\hline $\mathrm{H}$ & -5.479588 & 1.904077 & -1.479860 \\
\hline H & -2.723131 & 4.745687 & 0.596897 \\
\hline $\mathrm{H}$ & -3.270115 & 3.043304 & 0.515501 \\
\hline $\mathrm{H}$ & -3.150235 & 3.877299 & 2.079638 \\
\hline \multicolumn{4}{|c|}{3 Pdt1a (exo) } \\
\hline C & 1.300867 & -1.639963 & -0.566628 \\
\hline$N$ & 2.239354 & -1.533626 & 0.323777 \\
\hline C & 3.468641 & -1.798905 & -0.227392 \\
\hline C & 3.468852 & -2.145913 & -1.544414 \\
\hline$S$ & 1.863091 & -2.127017 & -2.142643 \\
\hline C & -0.120291 & -1.185975 & -0.313433 \\
\hline$N$ & -0.369351 & -1.143508 & 1.118461 \\
\hline C & -0.289119 & 0.291584 & -0.866336 \\
\hline C & -0.311953 & -2.286106 & 1.886802 \\
\hline $\mathrm{O}$ & -0.370897 & -3.404745 & 1.416475 \\
\hline C & 0.724006 & 1.215199 & -0.249965 \\
\hline $\mathrm{O}$ & -0.114582 & 0.278329 & -2.260114 \\
\hline C & -1.172648 & -2.022074 & -1.052645 \\
\hline C & -2.561716 & -1.506281 & -0.693689 \\
\hline C & -2.602223 & -0.005393 & -0.552633 \\
\hline C & -3.931172 & 0.588854 & -0.298365 \\
\hline $\mathrm{N}$ & -1.621707 & 0.808322 & -0.587936 \\
\hline
\end{tabular}




\begin{tabular}{|c|c|c|c|}
\hline $\mathrm{N}$ & -5.031221 & -0.096215 & -0.188864 \\
\hline C & -6.094362 & 0.734501 & 0.055795 \\
\hline C & -5.795552 & 2.064597 & 0.130666 \\
\hline$S$ & -4.119365 & 2.310464 & -0.113334 \\
\hline C & -7.480568 & 0.201923 & 0.227284 \\
\hline O & -8.423196 & 0.941444 & 0.445661 \\
\hline$N$ & -7.566231 & -1.145804 & 0.118054 \\
\hline C & 4.721333 & -1.629534 & 0.565158 \\
\hline$N$ & 4.512230 & -1.375997 & 1.877755 \\
\hline 0 & 5.822099 & -1.682431 & 0.038728 \\
\hline C & 0.628835 & 2.112364 & 0.759232 \\
\hline O & 1.870599 & 2.635045 & 0.961650 \\
\hline C & 2.657748 & 2.032484 & 0.049273 \\
\hline$N$ & 2.028841 & 1.191979 & -0.712161 \\
\hline C & 4.080711 & 2.316317 & 0.057026 \\
\hline N & 4.628875 & 3.435228 & 0.667506 \\
\hline C & 5.893360 & 3.303858 & 0.461993 \\
\hline O & 6.241183 & 2.195481 & -0.224327 \\
\hline C & 5.074614 & 1.559267 & -0.480157 \\
\hline C & -0.176713 & -2.026753 & 3.373463 \\
\hline H & 4.326060 & -2.399993 & -2.151195 \\
\hline $\mathrm{H}$ & -0.034562 & -0.300778 & 1.574082 \\
\hline $\mathrm{H}$ & 0.803222 & 0.546796 & -2.441362 \\
\hline $\mathrm{H}$ & -0.995463 & -1.906532 & -2.125754 \\
\hline H & -1.068365 & -3.072294 & -0.782891 \\
\hline $\mathrm{H}$ & -2.893875 & -1.923988 & 0.264603 \\
\hline $\mathrm{H}$ & -3.309951 & -1.810358 & -1.431768 \\
\hline $\mathrm{H}$ & -6.494177 & 2.869070 & 0.311858 \\
\hline $\mathrm{H}$ & -8.469240 & -1.583485 & 0.217143 \\
\hline H & -6.743528 & -1.699635 & -0.067370 \\
\hline H & 3.572347 & -1.320233 & 2.240116 \\
\hline $\mathrm{H}$ & 5.308311 & -1.226216 & 2.478405 \\
\hline $\mathrm{H}$ & -0.179275 & 2.497603 & 1.359275 \\
\hline $\mathrm{H}$ & 6.694431 & 3.961184 & 0.764943 \\
\hline H & 5.124045 & 0.611716 & -0.994830 \\
\hline H & 0.874786 & -1.822898 & 3.602269 \\
\hline $\mathrm{H}$ & -0.771806 & -1.168027 & 3.694659 \\
\hline $\mathrm{H}$ & -0.485659 & -2.919033 & 3.916509 \\
\hline \multicolumn{4}{|c|}{4 Pdt1a (endo) } \\
\hline C & -1.980825 & -1.735511 & -0.097612 \\
\hline N & -2.776522 & -0.914342 & -0.706506 \\
\hline C & -4.089323 & -1.291158 & -0.543346 \\
\hline C & -4.292837 & -2.416281 & 0.195527 \\
\hline S & -2.787100 & -3.041887 & 0.727418 \\
\hline H & -5.242984 & -2.875960 & 0.425711 \\
\hline
\end{tabular}




\begin{tabular}{|c|c|c|c|}
\hline C & -5.202480 & -0.491213 & -1.137520 \\
\hline 0 & -6.368487 & -0.817750 & -1.004011 \\
\hline $\mathrm{N}$ & -4.781667 & 0.606768 & -1.811689 \\
\hline $\mathrm{H}$ & -3.797858 & 0.823534 & -1.871273 \\
\hline $\mathrm{H}$ & -5.470769 & 1.215136 & -2.225620 \\
\hline C & -0.479880 & -1.556990 & -0.017978 \\
\hline $\mathrm{N}$ & 0.185480 & -2.825518 & 0.243344 \\
\hline C & 0.150206 & -3.880962 & -0.631637 \\
\hline 0 & -0.309904 & -3.791927 & -1.754553 \\
\hline C & 0.702855 & -5.176997 & -0.073722 \\
\hline $\mathrm{H}$ & 1.511853 & -5.012101 & 0.642045 \\
\hline $\mathrm{H}$ & 1.058178 & -5.789352 & -0.902138 \\
\hline $\mathrm{H}$ & -0.105128 & -5.716135 & 0.431752 \\
\hline $\mathrm{H}$ & 0.414203 & -2.999906 & 1.214665 \\
\hline C & 0.038033 & -0.878338 & -1.295674 \\
\hline $\mathrm{H}$ & -0.224377 & -1.499534 & -2.151510 \\
\hline $\mathrm{H}$ & -0.473033 & 0.080530 & -1.393792 \\
\hline C & 1.544582 & -0.675199 & -1.212598 \\
\hline C & 1.997560 & -0.281350 & 0.168911 \\
\hline $\mathrm{N}$ & 1.297122 & -0.281082 & 1.232345 \\
\hline C & -0.111215 & -0.631961 & 1.190913 \\
\hline C & -0.923061 & 0.635267 & 1.210089 \\
\hline C & -1.990434 & 0.908127 & 1.998481 \\
\hline 0 & -2.451769 & 2.138356 & 1.653676 \\
\hline C & -1.633796 & 2.549903 & 0.668334 \\
\hline$N$ & -0.699320 & 1.702751 & 0.362133 \\
\hline C & -1.860453 & 3.854815 & 0.074180 \\
\hline C & -1.128850 & 4.453639 & -0.900607 \\
\hline $\mathrm{O}$ & -1.697045 & 5.657972 & -1.151349 \\
\hline C & -2.749412 & 5.724941 & -0.308466 \\
\hline$N$ & -2.903575 & 4.691524 & 0.444034 \\
\hline $\mathrm{H}$ & -3.348440 & 6.622314 & -0.347245 \\
\hline $\mathrm{H}$ & -0.252673 & 4.180569 & -1.464793 \\
\hline $\mathrm{H}$ & -2.520809 & 0.374248 & 2.769274 \\
\hline 0 & -0.391742 & -1.373957 & 2.361445 \\
\hline $\mathrm{H}$ & 0.141486 & -0.964480 & 3.063073 \\
\hline C & 3.418712 & 0.094478 & 0.316132 \\
\hline$N$ & 4.276641 & 0.100542 & -0.661134 \\
\hline C & 5.514635 & 0.485795 & -0.214599 \\
\hline C & 5.594923 & 0.777303 & 1.116611 \\
\hline$S$ & 4.068400 & 0.567290 & 1.861700 \\
\hline $\mathrm{H}$ & 6.477864 & 1.098720 & 1.650600 \\
\hline C & 6.687093 & 0.573936 & -1.137933 \\
\hline 0 & 7.785142 & 0.918217 & -0.739557 \\
\hline $\mathrm{N}$ & 6.400215 & 0.240780 & -2.419425 \\
\hline
\end{tabular}




$\begin{array}{llll}\mathrm{H} & 5.469107 & -0.048493 & -2.678949 \\ \mathrm{H} & 7.140743 & 0.263826 & -3.103489 \\ \mathrm{H} & 1.884097 & 0.084906 & -1.922205 \\ \mathrm{H} & 2.083357 & -1.594968 & -1.473829\end{array}$

\section{Protonated diene}

$\begin{array}{lrrr}\text { 1 TS1a (exo) } & & & \\ \text { C } & 0.614085 & -2.297769 & 0.702832 \\ \text { N } & 1.386856 & -1.358321 & 1.185604 \\ \text { C } & 2.699191 & -1.615085 & 0.905978 \\ \text { C } & 2.935755 & -2.769793 & 0.212560 \\ \text { S } & 1.462615 & -3.575796 & -0.109564 \\ \text { C } & -0.843878 & -2.224300 & 0.789302 \\ \text { N } & -1.286680 & -1.159484 & 1.521141 \\ \text { C } & 0.140860 & 0.091468 & -1.454381 \\ \text { C } & -2.598419 & -0.821876 & 1.866305 \\ \text { O } & -3.553376 & -1.505387 & 1.563166 \\ \text { C } & 1.169676 & 1.032689 & -1.009568 \\ \text { O } & 0.626995 & -0.972646 & -2.114162 \\ \text { C } & -1.678887 & -3.045390 & 0.043266 \\ \text { C } & -1.963782 & -2.009465 & -1.679807 \\ \text { C } & -2.108797 & -0.635886 & -1.430096 \\ \text { C } & -3.386653 & -0.111574 & -1.114868 \\ \text { N } & -1.092347 & 0.282967 & -1.174498 \\ \text { N } & -3.548111 & 1.129669 & -0.639049 \\ \text { C } & -4.826680 & 1.477744 & -0.265547 \\ \text { C } & -5.709755 & 0.481590 & -0.491847 \\ \text { S } & -4.919040 & -0.911841 & -1.168345 \\ \text { C } & -4.932824 & 2.818250 & 0.394994 \\ \text { O } & -3.902553 & 3.347798 & 0.777750 \\ \text { N } & -6.170599 & 3.324929 & 0.550623 \\ \text { C } & 3.794387 & -0.654750 & 1.262870 \\ \text { N } & 3.389856 & 0.410646 & 1.990519 \\ \text { O } & 4.932773 & -0.843467 & 0.873143 \\ \text { C } & 1.113360 & 2.137123 & -0.221972 \\ \text { O } & 2.384831 & 2.562522 & -0.035855 \\ \text { C } & 3.165173 & 1.686258 & -0.703585 \\ \text { N } & 2.491790 & 0.756424 & -1.309345 \\ \text { C } & 4.603219 & 1.810252 & -0.589812 \\ \text { N } & 5.207152 & 2.381340 & 0.521342 \\ \text { C } & 6.464357 & 2.170854 & 0.325663 \\ \text { C } & 6.749210 & 1.520409 & -0.818507 \\ & 5.555617 & 1.281222 & -1.398237\end{array}$




\begin{tabular}{|c|c|c|c|}
\hline C & -2.706163 & 0.478575 & 2.623732 \\
\hline $\mathrm{H}$ & 3.897038 & -3.150012 & -0.103903 \\
\hline $\mathrm{H}$ & -0.542729 & -0.549255 & 1.850999 \\
\hline $\mathrm{H}$ & 1.597953 & -0.858313 & -2.190257 \\
\hline $\mathrm{H}$ & -1.236123 & -3.941202 & -0.382808 \\
\hline $\mathrm{H}$ & -2.716844 & -3.115216 & 0.340298 \\
\hline $\mathrm{H}$ & -2.858754 & -2.564611 & -1.952928 \\
\hline $\mathrm{H}$ & -1.057092 & -2.354942 & -2.158596 \\
\hline $\mathrm{H}$ & -6.766126 & 0.452391 & -0.267401 \\
\hline $\mathrm{H}$ & -6.252792 & 4.239395 & 0.975519 \\
\hline $\mathrm{H}$ & -6.971344 & 2.956289 & 0.059755 \\
\hline $\mathrm{H}$ & 2.424967 & 0.513660 & 2.264815 \\
\hline $\mathrm{H}$ & 4.048205 & 1.163617 & 2.157261 \\
\hline $\mathrm{H}$ & 0.324205 & 2.711157 & 0.235628 \\
\hline $\mathrm{H}$ & 7.298341 & 2.449857 & 0.951679 \\
\hline $\mathrm{H}$ & 5.548334 & 0.747676 & -2.334308 \\
\hline $\mathrm{H}$ & -2.623699 & 1.327374 & 1.933256 \\
\hline $\mathrm{H}$ & -3.684545 & 0.517406 & 3.102127 \\
\hline $\mathrm{H}$ & -1.925115 & 0.576551 & 3.382405 \\
\hline $\mathrm{H}$ & -2.748621 & 1.748541 & -0.512358 \\
\hline \multicolumn{4}{|c|}{2 Int1a (exo) } \\
\hline C & -0.746253 & 2.291770 & 0.619819 \\
\hline$N$ & -1.548028 & 1.409247 & 1.176598 \\
\hline C & -2.834843 & 1.634270 & 0.817774 \\
\hline C & -3.033522 & 2.715997 & -0.009925 \\
\hline$S$ & -1.551258 & 3.468353 & -0.366365 \\
\hline C & 0.692496 & 2.197968 & 0.746700 \\
\hline$N$ & 1.127645 & 1.237301 & 1.551752 \\
\hline C & -0.081227 & -0.149705 & -1.348614 \\
\hline C & 2.482895 & 0.875033 & 1.880274 \\
\hline $\mathrm{O}$ & 3.387477 & 1.660324 & 1.784307 \\
\hline C & -1.115743 & -1.067400 & -0.867318 \\
\hline $\mathrm{O}$ & -0.559511 & 0.842525 & -2.130510 \\
\hline C & 1.608315 & 2.945667 & -0.115319 \\
\hline C & 1.922442 & 2.084705 & -1.454918 \\
\hline C & 2.149831 & 0.639600 & -1.215319 \\
\hline C & 3.419998 & 0.154889 & -0.970507 \\
\hline$N$ & 1.138652 & -0.287368 & -0.988137 \\
\hline$N$ & 3.685602 & -1.134010 & -0.628397 \\
\hline C & 4.990803 & -1.407883 & -0.285415 \\
\hline C & 5.801300 & -0.338010 & -0.403772 \\
\hline$S$ & 4.913523 & 1.068428 & -0.946974 \\
\hline C & 5.220530 & -2.790026 & 0.240903 \\
\hline $\mathrm{O}$ & 4.253617 & -3.438853 & 0.602481 \\
\hline$N$ & 6.503246 & -3.204238 & 0.313663 \\
\hline
\end{tabular}




\begin{tabular}{|c|c|c|c|}
\hline C & -3.952899 & 0.707394 & 1.202470 \\
\hline N & -3.591782 & -0.290387 & 2.037758 \\
\hline O & -5.064968 & 0.868753 & 0.734856 \\
\hline C & -1.078095 & -2.102436 & 0.011743 \\
\hline 0 & -2.352139 & -2.532592 & 0.183527 \\
\hline C & -3.115180 & -1.729183 & -0.585792 \\
\hline$N$ & -2.430641 & -0.838442 & -1.237036 \\
\hline C & -4.554937 & -1.882588 & -0.540257 \\
\hline$N$ & -5.212170 & -2.388209 & 0.572667 \\
\hline C & -6.460273 & -2.241817 & 0.281977 \\
\hline O & -6.690343 & -1.693174 & -0.925719 \\
\hline C & -5.469498 & -1.455296 & -1.446943 \\
\hline C & 2.582933 & -0.541362 & 2.368177 \\
\hline $\mathrm{H}$ & -3.980222 & 3.058942 & -0.404977 \\
\hline $\mathrm{H}$ & 0.391258 & 0.630058 & 1.915876 \\
\hline H & -1.516181 & 0.679109 & -2.261294 \\
\hline $\mathrm{H}$ & 1.162751 & 3.888063 & -0.439846 \\
\hline $\mathrm{H}$ & 2.551577 & 3.136022 & 0.391778 \\
\hline $\mathrm{H}$ & 2.811864 & 2.562462 & -1.875039 \\
\hline $\mathrm{H}$ & 1.092250 & 2.256091 & -2.136899 \\
\hline $\mathrm{H}$ & 6.853234 & -0.261831 & -0.171633 \\
\hline $\mathrm{H}$ & 6.670020 & -4.148983 & 0.633913 \\
\hline $\mathrm{H}$ & 7.242464 & -2.738790 & -0.191234 \\
\hline $\mathrm{H}$ & -2.634995 & -0.390536 & 2.340723 \\
\hline $\mathrm{H}$ & -4.247733 & -1.048304 & 2.194762 \\
\hline $\mathrm{H}$ & -0.300207 & -2.631057 & 0.538080 \\
\hline $\mathrm{H}$ & -7.323862 & -2.502970 & 0.874749 \\
\hline $\mathrm{H}$ & -5.418419 & -1.000711 & -2.422557 \\
\hline $\mathrm{H}$ & 2.176357 & -1.223087 & 1.613053 \\
\hline $\mathrm{H}$ & 3.629740 & -0.779866 & 2.553312 \\
\hline $\mathrm{H}$ & 2.014043 & -0.669654 & 3.295571 \\
\hline $\mathrm{H}$ & 2.954661 & -1.836124 & -0.572940 \\
\hline \multicolumn{4}{|c|}{3 TS2a (exo) } \\
\hline C & 1.320211 & -1.727561 & 0.485309 \\
\hline$N$ & 2.112299 & -0.961911 & 1.187779 \\
\hline C & 3.428238 & -1.197721 & 0.882723 \\
\hline C & 3.650587 & -2.170842 & -0.045002 \\
\hline$S$ & 2.156540 & -2.820454 & -0.580967 \\
\hline C & -0.137503 & -1.511548 & 0.462641 \\
\hline N & -0.511823 & -0.775155 & 1.621737 \\
\hline C & -0.251743 & -0.255686 & -1.158172 \\
\hline C & -1.754844 & -0.620946 & 2.162716 \\
\hline O & -2.786666 & -1.000860 & 1.620425 \\
\hline C & 0.733237 & 0.792278 & -0.870967 \\
\hline 0 & 0.070887 & -1.043497 & -2.227166 \\
\hline
\end{tabular}




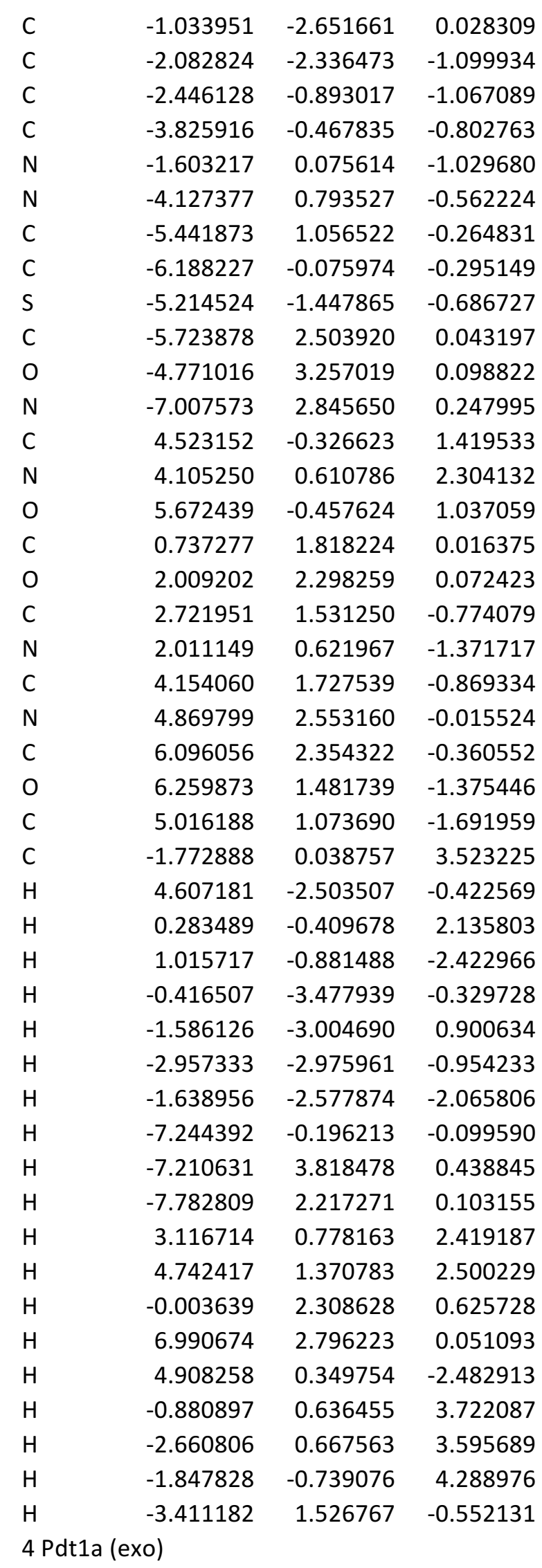




\begin{tabular}{|c|c|c|c|}
\hline C & 1.444904 & -1.778477 & 0.080243 \\
\hline$N$ & 2.219812 & -1.168436 & 0.927674 \\
\hline C & 3.542138 & -1.314094 & 0.590354 \\
\hline C & 3.778515 & -2.081006 & -0.510941 \\
\hline S & 2.294810 & -2.624093 & -1.173436 \\
\hline C & -0.045304 & -1.498613 & 0.051236 \\
\hline$N$ & -0.411195 & -1.137242 & 1.419777 \\
\hline C & -0.259828 & -0.241018 & -0.915941 \\
\hline C & -1.598709 & -1.314757 & 2.056450 \\
\hline $\mathrm{O}$ & -2.627193 & -1.701552 & 1.505934 \\
\hline C & 0.685903 & 0.860367 & -0.549508 \\
\hline $\mathrm{O}$ & -0.046539 & -0.660989 & -2.232467 \\
\hline C & -0.873593 & -2.662094 & -0.519537 \\
\hline C & -2.178308 & -2.203365 & -1.213346 \\
\hline C & -2.490197 & -0.774117 & -0.882371 \\
\hline C & -3.889635 & -0.355084 & -0.631569 \\
\hline$N$ & -1.652136 & 0.173051 & -0.752347 \\
\hline$N$ & -4.202587 & 0.910564 & -0.439438 \\
\hline C & -5.524348 & 1.172588 & -0.173795 \\
\hline C & -6.256517 & 0.028645 & -0.170016 \\
\hline$S$ & -5.263195 & -1.345257 & -0.490542 \\
\hline C & -5.824802 & 2.630635 & 0.065601 \\
\hline $\mathrm{O}$ & -4.879756 & 3.394449 & 0.085730 \\
\hline$N$ & -7.112569 & 2.966247 & 0.250449 \\
\hline C & 4.610571 & -0.507957 & 1.264283 \\
\hline$N$ & 4.171785 & 0.240602 & 2.306012 \\
\hline $\mathrm{O}$ & 5.755540 & -0.514395 & 0.848758 \\
\hline C & 0.693833 & 1.739806 & 0.478149 \\
\hline $\mathrm{O}$ & 1.939274 & 2.288382 & 0.533990 \\
\hline C & 2.629736 & 1.709282 & -0.465426 \\
\hline$N$ & 1.925828 & 0.864780 & -1.159118 \\
\hline C & 4.049524 & 1.972472 & -0.589369 \\
\hline$N$ & 4.783917 & 2.651494 & 0.371420 \\
\hline C & 5.998640 & 2.550574 & -0.049153 \\
\hline $\mathrm{O}$ & 6.137752 & 1.876434 & -1.208406 \\
\hline C & 4.890015 & 1.496555 & -1.545660 \\
\hline C & -1.571666 & -1.016301 & 3.539713 \\
\hline $\mathrm{H}$ & 4.739994 & -2.317285 & -0.944884 \\
\hline $\mathrm{H}$ & 0.384466 & -0.839200 & 1.974240 \\
\hline $\mathrm{H}$ & 0.818173 & -0.305556 & -2.512684 \\
\hline $\mathrm{H}$ & -0.268041 & -3.199024 & -1.251085 \\
\hline H & -1.108512 & -3.352240 & 0.291601 \\
\hline $\mathrm{H}$ & -3.004277 & -2.853784 & -0.915618 \\
\hline H & -2.062460 & -2.267362 & -2.299916 \\
\hline H & -7.314023 & -0.095827 & 0.016754 \\
\hline
\end{tabular}




$\begin{array}{lrrr}\mathrm{H} & -7.327453 & 3.944339 & 0.397067 \\ \mathrm{H} & -7.880354 & 2.320840 & 0.146457 \\ \mathrm{H} & 3.179564 & 0.344771 & 2.458510 \\ \mathrm{H} & 4.780849 & 0.983130 & 2.622195 \\ \mathrm{H} & -0.025016 & 2.074122 & 1.207802 \\ \mathrm{H} & 6.900472 & 2.936119 & 0.401531 \\ \mathrm{H} & 4.764048 & 0.919089 & -2.446747 \\ \mathrm{H} & -0.736480 & -0.378789 & 3.836672 \\ \mathrm{H} & -2.513730 & -0.542982 & 3.818229 \\ \mathrm{H} & -1.498787 & -1.962705 & 4.083471 \\ \mathrm{H} & -3.492110 & 1.651655 & -0.455634\end{array}$

\section{Deprotonated dienophile}

$\begin{array}{lrrr}\text { 1 TS1a (exo) } & & & \\ \text { C } & -0.774390 & 1.642157 & 0.602995 \\ \text { N } & -1.671625 & 2.215587 & -0.163517 \\ \text { C } & -2.940094 & 1.994913 & 0.312774 \\ \text { C } & -3.032586 & 1.260479 & 1.456692 \\ \text { S } & -1.461213 & 0.781446 & 1.971996 \\ \text { C } & 0.683573 & 1.715199 & 0.461251 \\ \text { N } & 1.349641 & 1.002095 & 1.349798 \\ \text { C } & -0.239273 & -0.473660 & -1.478511 \\ \text { C } & 2.719570 & 1.087757 & 1.466514 \\ \text { O } & 3.443017 & 1.994755 & 1.052834 \\ \text { C } & -1.310902 & -1.236399 & -0.851177 \\ \text { O } & -0.628855 & 0.547786 & -2.294581 \\ \text { C } & 1.222091 & 2.469597 & -0.637102 \\ \text { C } & 2.071877 & 1.271831 & -1.914473 \\ \text { C } & 2.081735 & -0.091803 & -1.473910 \\ \text { C } & 3.315419 & -0.676792 & -1.024728 \\ \text { N } & 0.973260 & -0.839990 & -1.247992 \\ \text { N } & 4.430470 & -0.027151 & -0.812982 \\ \text { C } & 5.397164 & -0.849461 & -0.299431 \\ \text { C } & 5.076581 & -2.166285 & -0.175100 \\ \text { S } & 3.434138 & -2.411411 & -0.669725 \\ \text { C } & 6.625715 & -0.235228 & 0.286430 \\ \text { O } & 7.651092 & -0.862759 & 0.515264 \\ \text { N } & 6.450624 & 1.079611 & 0.586506 \\ \text { C } & -4.100252 & 2.541806 & -0.437984 \\ \text { N } & -3.746052 & 3.309287 & -1.495704 \\ \text { O } & -5.267054 & 2.316225 & -0.129985 \\ \text { C } & -1.206568 & -2.266206 & 0.033419 \\ \text { O } & -2.462009 & -2.593221 & 0.439069\end{array}$




\begin{tabular}{|c|c|c|c|}
\hline C & -3.270992 & -1.724976 & -0.200414 \\
\hline$N$ & -2.651118 & -0.899529 & -0.986403 \\
\hline C & -4.694521 & -1.796246 & 0.089955 \\
\hline$N$ & -5.314942 & -2.963339 & 0.526314 \\
\hline C & -6.547380 & -2.618871 & 0.665002 \\
\hline $\mathrm{O}$ & -6.814006 & -1.331784 & 0.368206 \\
\hline C & -5.615281 & -0.801246 & 0.002096 \\
\hline C & 3.302962 & -0.061633 & 2.262265 \\
\hline $\mathrm{H}$ & -3.937350 & 0.982498 & 1.978466 \\
\hline $\mathrm{H}$ & -1.472320 & 0.898315 & -1.948434 \\
\hline $\mathrm{H}$ & 0.472982 & 2.994479 & -1.223152 \\
\hline $\mathrm{H}$ & 2.099759 & 3.048764 & -0.378581 \\
\hline $\mathrm{H}$ & 3.065782 & 1.700240 & -2.009205 \\
\hline $\mathrm{H}$ & 1.402702 & 1.495111 & -2.738070 \\
\hline $\mathrm{H}$ & 5.694459 & -2.951751 & 0.233807 \\
\hline $\mathrm{H}$ & 7.173718 & 1.521584 & 1.133633 \\
\hline $\mathrm{H}$ & 5.513167 & 1.483441 & 0.566572 \\
\hline $\mathrm{H}$ & -2.767429 & 3.447390 & -1.705624 \\
\hline $\mathrm{H}$ & -4.469029 & 3.687281 & -2.086916 \\
\hline $\mathrm{H}$ & -0.378365 & -2.818576 & 0.443259 \\
\hline $\mathrm{H}$ & -7.380021 & -3.227903 & 0.984543 \\
\hline $\mathrm{H}$ & -5.583425 & 0.254079 & -0.237394 \\
\hline $\mathrm{H}$ & 2.850722 & -0.084280 & 3.258757 \\
\hline $\mathrm{H}$ & 3.055550 & -1.008904 & 1.771881 \\
\hline $\mathrm{H}$ & 4.386328 & 0.044076 & 2.342149 \\
\hline \multicolumn{4}{|c|}{$2 \operatorname{lnt1} a$ (exo) } \\
\hline C & -0.373590 & 1.720419 & -0.562104 \\
\hline$N$ & 0.566143 & 2.147146 & 0.227112 \\
\hline C & 1.802080 & 1.957494 & -0.339382 \\
\hline C & 1.806038 & 1.379556 & -1.575788 \\
\hline$S$ & 0.199861 & 1.041129 & -2.068728 \\
\hline $\mathrm{H}$ & 2.675547 & 1.131867 & -2.167914 \\
\hline C & 3.039436 & 2.307873 & 0.410413 \\
\hline 0 & 4.151710 & 2.281798 & -0.103898 \\
\hline$N$ & 2.808327 & 2.667378 & 1.697863 \\
\hline $\mathrm{H}$ & 3.606785 & 2.785414 & 2.302862 \\
\hline $\mathrm{H}$ & 1.894339 & 2.476403 & 2.092634 \\
\hline C & -1.821831 & 1.756273 & -0.268174 \\
\hline$N$ & -2.581497 & 1.581377 & -1.287207 \\
\hline C & -3.981774 & 1.603661 & -1.209265 \\
\hline 0 & -4.626833 & 2.430258 & -0.588136 \\
\hline C & -4.612408 & 0.595715 & -2.139287 \\
\hline $\mathrm{H}$ & -4.436164 & 0.925048 & -3.169278 \\
\hline $\mathrm{H}$ & -4.145381 & -0.385661 & -2.018532 \\
\hline $\mathrm{H}$ & -5.684770 & 0.531708 & -1.951704 \\
\hline
\end{tabular}




\begin{tabular}{|c|c|c|c|}
\hline C & -2.218438 & 1.980935 & 1.175121 \\
\hline $\mathrm{H}$ & -3.303981 & 1.973268 & 1.232748 \\
\hline $\mathrm{H}$ & -1.867973 & 2.976999 & 1.476094 \\
\hline C & -1.610647 & 0.870456 & 2.063698 \\
\hline C & -1.417121 & -0.405105 & 1.266179 \\
\hline$N$ & -0.230040 & -0.970475 & 0.928383 \\
\hline C & 0.954302 & -0.693016 & 1.320837 \\
\hline C & 2.098129 & -1.256573 & 0.619340 \\
\hline C & 2.188499 & -2.172462 & -0.384553 \\
\hline 0 & 3.502577 & -2.255153 & -0.758451 \\
\hline C & 4.143768 & -1.377563 & 0.029435 \\
\hline$N$ & 3.375017 & -0.765199 & 0.875641 \\
\hline C & 5.559841 & -1.135462 & -0.190703 \\
\hline C & 6.214313 & 0.035427 & 0.017330 \\
\hline 0 & 7.518839 & -0.169406 & -0.308169 \\
\hline C & 7.575715 & -1.457150 & -0.706666 \\
\hline $\mathrm{N}$ & 6.454371 & -2.088661 & -0.665991 \\
\hline $\mathrm{H}$ & 8.541857 & -1.828610 & -1.014603 \\
\hline $\mathrm{H}$ & 5.893112 & 1.024107 & 0.311573 \\
\hline $\mathrm{H}$ & 1.477385 & -2.787867 & -0.907803 \\
\hline 0 & 1.297841 & 0.167374 & 2.355556 \\
\hline $\mathrm{H}$ & 2.270739 & 0.207118 & 2.351666 \\
\hline C & -2.567809 & -1.031149 & 0.758046 \\
\hline$N$ & -3.818357 & -0.592098 & 0.881474 \\
\hline C & -4.703358 & -1.474348 & 0.316292 \\
\hline C & -4.190007 & -2.584768 & -0.277200 \\
\hline$S$ & -2.458741 & -2.573778 & -0.137242 \\
\hline $\mathrm{H}$ & -4.741963 & -3.357279 & -0.790940 \\
\hline C & -6.156478 & -1.144875 & 0.268941 \\
\hline 0 & -7.004438 & -1.916336 & -0.159998 \\
\hline$N$ & -6.449075 & 0.102631 & 0.736449 \\
\hline $\mathrm{H}$ & -5.689769 & 0.765076 & 0.845217 \\
\hline $\mathrm{H}$ & -7.370347 & 0.456941 & 0.527158 \\
\hline $\mathrm{H}$ & -0.649904 & 1.191170 & 2.461143 \\
\hline $\mathrm{H}$ & -2.291211 & 0.701674 & 2.908848 \\
\hline \multicolumn{4}{|c|}{3 TS2a (exo) } \\
\hline C & 1.048073 & -1.483863 & 0.535445 \\
\hline$N$ & 1.925131 & -2.105171 & -0.214103 \\
\hline C & 3.189307 & -1.981975 & 0.316789 \\
\hline C & 3.281601 & -1.300192 & 1.491339 \\
\hline$S$ & 1.724344 & -0.743974 & 1.970731 \\
\hline $\mathrm{H}$ & 4.183127 & -1.106898 & 2.054898 \\
\hline C & 4.355478 & -2.534129 & -0.417870 \\
\hline $\mathrm{O}$ & 5.515077 & -2.253654 & -0.131619 \\
\hline $\mathrm{N}$ & 4.018416 & -3.372446 & -1.430559 \\
\hline
\end{tabular}




\begin{tabular}{|c|c|c|c|}
\hline $\mathrm{H}$ & 4.743242 & -3.669037 & -2.065270 \\
\hline $\mathrm{H}$ & 3.044889 & -3.457205 & -1.687678 \\
\hline C & -0.355322 & -1.200077 & 0.207032 \\
\hline $\mathrm{N}$ & -0.995714 & -0.479874 & 1.193552 \\
\hline C & -2.267755 & -0.703958 & 1.541565 \\
\hline 0 & -3.022215 & -1.662788 & 1.244501 \\
\hline C & -2.861167 & 0.393258 & 2.417752 \\
\hline $\mathrm{H}$ & -2.089126 & 1.046377 & 2.827022 \\
\hline $\mathrm{H}$ & -3.541310 & 0.994545 & 1.798718 \\
\hline $\mathrm{H}$ & -3.458844 & -0.049907 & 3.219927 \\
\hline C & -1.049615 & -2.244534 & -0.642973 \\
\hline $\mathrm{H}$ & -1.560532 & -2.929954 & 0.033573 \\
\hline $\mathrm{H}$ & -0.298649 & -2.786608 & -1.219121 \\
\hline C & -2.123184 & -1.648384 & -1.604101 \\
\hline C & -2.214905 & -0.151677 & -1.521969 \\
\hline$N$ & -1.216042 & 0.650949 & -1.439092 \\
\hline C & 0.055800 & 0.093720 & -1.306831 \\
\hline C & 1.050023 & 1.048539 & -0.796088 \\
\hline C & 0.848991 & 2.102300 & 0.036688 \\
\hline 0 & 2.072145 & 2.580140 & 0.407924 \\
\hline C & 2.955787 & 1.768952 & -0.205831 \\
\hline $\mathrm{N}$ & 2.416467 & 0.847603 & -0.940940 \\
\hline C & 4.372875 & 1.967655 & 0.059879 \\
\hline C & 5.365361 & 1.041217 & -0.007144 \\
\hline 0 & 6.526776 & 1.672418 & 0.319665 \\
\hline C & 6.167838 & 2.945498 & 0.575147 \\
\hline$N$ & 4.911081 & 3.192095 & 0.444131 \\
\hline $\mathrm{H}$ & 6.956568 & 3.626064 & 0.860034 \\
\hline $\mathrm{H}$ & 5.416442 & -0.020232 & -0.213060 \\
\hline $\mathrm{H}$ & -0.026792 & 2.580175 & 0.440660 \\
\hline 0 & 0.504221 & -0.707307 & -2.340142 \\
\hline $\mathrm{H}$ & 1.309241 & -1.147321 & -1.999439 \\
\hline C & -3.534114 & 0.442216 & -1.257924 \\
\hline $\mathrm{N}$ & -4.502898 & -0.248093 & -0.745999 \\
\hline C & -5.500880 & 0.560384 & -0.275743 \\
\hline C & -5.338034 & 1.893568 & -0.515585 \\
\hline$S$ & -3.818872 & 2.171451 & -1.281669 \\
\hline $\mathrm{H}$ & -6.003204 & 2.693487 & -0.223903 \\
\hline C & -6.504287 & -0.027276 & 0.666964 \\
\hline 0 & -7.594615 & 0.484608 & 0.882969 \\
\hline$N$ & -6.023327 & -1.133064 & 1.284587 \\
\hline $\mathrm{H}$ & -5.029539 & -1.392512 & 1.216370 \\
\hline $\mathrm{H}$ & -6.582525 & -1.507026 & 2.03685 \\
\hline $\mathrm{H}$ & -1.842423 & -1.902980 & -2.631154 \\
\hline $\mathrm{H}$ & -3.102238 & -2.069399 & -1.380079 \\
\hline
\end{tabular}




\begin{tabular}{|c|c|c|c|}
\hline \multicolumn{4}{|c|}{4 Pdt1a (exo) } \\
\hline C & 1.372918 & -1.475716 & 0.742628 \\
\hline$N$ & 2.056658 & -2.127416 & -0.152577 \\
\hline C & 3.401165 & -2.096754 & 0.147164 \\
\hline C & 3.732245 & -1.454088 & 1.301746 \\
\hline$S$ & 2.321128 & -0.820131 & 2.052884 \\
\hline $\mathrm{H}$ & 4.729613 & -1.334727 & 1.701473 \\
\hline C & 4.388132 & -2.663026 & -0.805731 \\
\hline $\mathrm{O}$ & 5.588203 & -2.423641 & -0.733758 \\
\hline$N$ & 3.837682 & -3.459049 & -1.760695 \\
\hline $\mathrm{H}$ & 4.417744 & -3.726027 & -2.541169 \\
\hline $\mathrm{H}$ & 2.831061 & -3.469063 & -1.853241 \\
\hline C & -0.064616 & -1.023743 & 0.637499 \\
\hline $\mathrm{N}$ & -0.313940 & -0.290598 & 1.853924 \\
\hline C & -1.534985 & -0.200764 & 2.357058 \\
\hline 0 & -2.622585 & -0.660949 & 1.925011 \\
\hline C & -1.601237 & 0.602375 & 3.656537 \\
\hline $\mathrm{H}$ & -0.612566 & 0.923260 & 3.989330 \\
\hline $\mathrm{H}$ & -2.239825 & 1.478217 & 3.497313 \\
\hline $\mathrm{H}$ & -2.079531 & -0.005347 & 4.431403 \\
\hline C & -0.986954 & -2.211430 & 0.275477 \\
\hline $\mathrm{H}$ & -1.311351 & -2.668351 & 1.211336 \\
\hline $\mathrm{H}$ & -0.404446 & -2.941023 & -0.294011 \\
\hline C & -2.224522 & -1.789338 & -0.544778 \\
\hline C & -2.375915 & -0.293392 & -0.589340 \\
\hline $\mathrm{N}$ & -1.423650 & 0.551452 & -0.663029 \\
\hline C & -0.098521 & -0.040486 & -0.619817 \\
\hline C & 0.944064 & 1.030308 & -0.468979 \\
\hline C & 0.899135 & 2.211844 & 0.185845 \\
\hline O & 2.158047 & 2.741814 & 0.189356 \\
\hline C & 2.908807 & 1.832961 & -0.463491 \\
\hline N & 2.246646 & 0.806408 & -0.892218 \\
\hline C & 4.347431 & 2.031103 & -0.545909 \\
\hline C & 5.296868 & 1.072344 & -0.715632 \\
\hline $\mathrm{O}$ & 6.504330 & 1.700810 & -0.731424 \\
\hline C & 6.216234 & 3.005396 & -0.559779 \\
\hline$N$ & 4.962536 & 3.274081 & -0.441084 \\
\hline $\mathrm{H}$ & 7.051508 & 3.689721 & -0.539454 \\
\hline $\mathrm{H}$ & 5.295934 & -0.005713 & -0.806114 \\
\hline $\mathrm{H}$ & 0.122774 & 2.759033 & 0.692145 \\
\hline 0 & 0.120670 & -0.753196 & -1.818398 \\
\hline $\mathrm{H}$ & 1.024346 & -1.111094 & -1.746154 \\
\hline C & -3.740876 & 0.271271 & -0.572561 \\
\hline$N$ & -4.843396 & -0.397808 & -0.709995 \\
\hline C & -5.931700 & 0.439115 & -0.637272 \\
\hline
\end{tabular}




$\begin{array}{lrrr}\mathrm{C} & -5.650575 & 1.758401 & -0.442789 \\ \mathrm{~S} & -3.954300 & 1.989452 & -0.349314 \\ \mathrm{H} & -6.368622 & 2.560497 & -0.352585 \\ \mathrm{C} & -7.313288 & -0.105459 & -0.747603 \\ \mathrm{O} & -8.308266 & 0.600380 & -0.689772 \\ \mathrm{~N} & -7.346689 & -1.452236 & -0.929497 \\ \mathrm{H} & -6.487691 & -1.978730 & -0.852377 \\ \mathrm{H} & -8.240309 & -1.916505 & -0.893377 \\ \mathrm{H} & -2.119669 & -2.130750 & -1.580952 \\ \mathrm{H} & -3.135191 & -2.213664 & -0.124254\end{array}$

\section{Deprotonated diene}

$\begin{array}{lrrr}\text { 1 TS1a (exo) } & & & \\ \text { C } & 0.772894 & 1.744809 & 0.196184 \\ \text { N } & 1.537831 & 1.331661 & -0.808123 \\ \text { C } & 2.859487 & 1.598372 & -0.552198 \\ \text { C } & 3.153905 & 2.191562 & 0.635035 \\ \text { S } & 1.701608 & 2.425885 & 1.541147 \\ \text { C } & -0.639973 & 1.678354 & 0.206371 \\ \text { N } & -1.200990 & 1.037417 & -0.920733 \\ \text { C } & 0.149345 & -0.865595 & 1.908987 \\ \text { C } & -2.420903 & 1.228936 & -1.471287 \\ \text { O } & -3.221483 & 2.097712 & -1.119485 \\ \text { C } & 1.251891 & -1.330474 & 1.023909 \\ \text { O } & 0.387840 & -0.318095 & 2.977839 \\ \text { C } & -1.486770 & 2.138676 & 1.245048 \\ \text { C } & -2.204112 & 0.749178 & 2.404002 \\ \text { C } & -2.143704 & -0.457502 & 1.645507 \\ \text { C } & -3.350685 & -0.859444 & 0.903008 \\ \text { N } & -1.071002 & -1.154763 & 1.333008 \\ \text { N } & -4.349019 & -0.081608 & 0.607748 \\ \text { C } & -5.279430 & -0.741733 & -0.155444 \\ \text { C } & -5.019091 & -2.056763 & -0.407025 \\ \text { S } & -3.497838 & -2.493057 & 0.272480 \\ \text { C } & -6.393446 & 0.011359 & -0.808932 \\ \text { O } & -7.406934 & -0.540779 & -1.214815 \\ \text { N } & -6.129217 & 1.334147 & -0.941696 \\ \text { C } & 3.915356 & 1.151107 & -1.503246 \\ \text { N } & 3.434797 & 0.408683 & -2.541979 \\ \text { O } & 5.105020 & 1.399053 & -1.347829 \\ \text { C } & 1.137611 & -1.899918 & -0.205730 \\ \text { O } & 2.386458 & -2.033403 & -0.729126 \\ \text { C } & 3.199428 & -1.518364 & 0.222509\end{array}$




\begin{tabular}{|c|c|c|c|}
\hline$N$ & 2.590021 & -1.098217 & 1.283330 \\
\hline C & 4.620372 & -1.408507 & -0.049839 \\
\hline $\mathrm{N}$ & 5.228176 & -1.790557 & -1.239323 \\
\hline C & 6.447155 & -1.396463 & -1.096126 \\
\hline $\mathrm{O}$ & 6.720255 & -0.806968 & 0.081989 \\
\hline C & 5.538794 & -0.806346 & 0.745938 \\
\hline C & -2.787712 & 0.222482 & -2.545154 \\
\hline $\mathrm{H}$ & 4.133006 & 2.444241 & 1.012391 \\
\hline $\mathrm{H}$ & -0.998266 & 2.777476 & 1.978578 \\
\hline $\mathrm{H}$ & -2.450171 & 2.512378 & 0.915767 \\
\hline $\mathrm{H}$ & -3.207595 & 1.113835 & 2.602190 \\
\hline $\mathrm{H}$ & -1.507643 & 0.802622 & 3.229800 \\
\hline $\mathrm{H}$ & -5.624670 & -2.733416 & -0.992258 \\
\hline $\mathrm{H}$ & -6.773618 & 1.864657 & -1.509136 \\
\hline $\mathrm{H}$ & -5.176295 & 1.682288 & -0.819322 \\
\hline $\mathrm{H}$ & 2.480013 & 0.084544 & -2.453457 \\
\hline $\mathrm{H}$ & 4.102542 & -0.209681 & -2.981887 \\
\hline $\mathrm{H}$ & 0.304413 & -2.248436 & -0.793058 \\
\hline $\mathrm{H}$ & 7.264769 & -1.487175 & -1.795039 \\
\hline $\mathrm{H}$ & 5.496216 & -0.338516 & 1.714989 \\
\hline $\mathrm{H}$ & -1.914948 & -0.181572 & -3.065758 \\
\hline $\mathrm{H}$ & -3.327399 & -0.609886 & -2.079098 \\
\hline $\mathrm{H}$ & -3.455341 & 0.702603 & -3.262415 \\
\hline $\mathrm{H}$ & -0.581251 & 0.368938 & -1.363617 \\
\hline \multicolumn{4}{|c|}{2 Int1a (exo) } \\
\hline C & 0.774411 & 1.532526 & 0.750460 \\
\hline $\mathrm{N}$ & 1.620528 & 1.477103 & -0.297378 \\
\hline C & 2.907098 & 1.705464 & 0.112664 \\
\hline C & 3.141205 & 1.891396 & 1.436862 \\
\hline$S$ & 1.631883 & 1.781473 & 2.309416 \\
\hline $\mathrm{H}$ & 4.088170 & 2.082050 & 1.917443 \\
\hline C & 4.002784 & 1.693053 & -0.899311 \\
\hline O & 5.187893 & 1.853881 & -0.626023 \\
\hline$N$ & 3.555017 & 1.457685 & -2.165646 \\
\hline $\mathrm{H}$ & 4.234500 & 1.095408 & -2.818707 \\
\hline $\mathrm{H}$ & 2.594203 & 1.145440 & -2.238787 \\
\hline C & -0.594716 & 1.397208 & 0.669917 \\
\hline$N$ & -1.090155 & 1.080722 & -0.620809 \\
\hline C & -2.231639 & 1.522934 & -1.184765 \\
\hline $\mathrm{O}$ & -3.010958 & 2.320611 & -0.651309 \\
\hline C & -2.576241 & 0.887022 & -2.519221 \\
\hline $\mathrm{H}$ & -1.721016 & 0.406201 & -3.002630 \\
\hline $\mathrm{H}$ & -3.353198 & 0.130442 & -2.356553 \\
\hline $\mathrm{H}$ & -2.989039 & 1.652441 & -3.179581 \\
\hline C & -1.561557 & 1.363407 & 1.795213 \\
\hline
\end{tabular}




\begin{tabular}{|c|c|c|c|}
\hline $\mathrm{H}$ & -2.502006 & 1.826152 & 1.486744 \\
\hline $\mathrm{H}$ & -1.168190 & 1.939021 & 2.641029 \\
\hline C & -1.892535 & -0.072409 & 2.347676 \\
\hline C & -2.072503 & -1.080604 & 1.257170 \\
\hline $\mathrm{N}$ & -1.180030 & -1.882209 & 0.804889 \\
\hline C & 0.089496 & -1.976863 & 1.401308 \\
\hline C & 1.171275 & -1.785312 & 0.413120 \\
\hline C & 1.066144 & -1.676435 & -0.938775 \\
\hline 0 & 2.312262 & -1.493736 & -1.440794 \\
\hline C & 3.113675 & -1.476676 & -0.348481 \\
\hline $\mathrm{N}$ & 2.497970 & -1.660379 & 0.773518 \\
\hline C & 4.533009 & -1.226477 & -0.511551 \\
\hline C & 5.400728 & -0.936969 & 0.490045 \\
\hline 0 & 6.606325 & -0.691858 & -0.072096 \\
\hline C & 6.397416 & -0.821319 & -1.395608 \\
\hline$N$ & 5.196768 & -1.152165 & -1.728799 \\
\hline $\mathrm{H}$ & 7.245370 & -0.646420 & -2.040070 \\
\hline $\mathrm{H}$ & 5.300295 & -0.835716 & 1.557584 \\
\hline $\mathrm{H}$ & 0.246529 & -1.743010 & -1.636063 \\
\hline 0 & 0.291925 & -2.264804 & 2.560724 \\
\hline C & -3.356257 & -1.084006 & 0.528309 \\
\hline $\mathrm{N}$ & -4.224704 & -0.120399 & 0.565493 \\
\hline C & -5.273478 & -0.374604 & -0.281255 \\
\hline C & -5.225848 & -1.571690 & -0.935956 \\
\hline$S$ & -3.777921 & -2.406916 & -0.541032 \\
\hline $\mathrm{H}$ & -5.957602 & -1.951744 & $-1.63417 \epsilon$ \\
\hline C & -6.319041 & 0.661302 & -0.555605 \\
\hline 0 & -7.423211 & 0.358971 & -0.986834 \\
\hline$N$ & -5.894590 & 1.922857 & -0.315013 \\
\hline $\mathrm{H}$ & -4.890980 & 2.116202 & -0.250595 \\
\hline $\mathrm{H}$ & -6.507834 & 2.662120 & -0.626666 \\
\hline $\mathrm{H}$ & -1.083553 & -0.410490 & 2.995625 \\
\hline $\mathrm{H}$ & -2.816436 & -0.013520 & 2.931029 \\
\hline $\mathrm{H}$ & -0.422689 & 0.599791 & -1.216196 \\
\hline \multicolumn{4}{|c|}{3 TS2a (exo) } \\
\hline C & 1.328217 & -1.665533 & -0.447077 \\
\hline$N$ & 2.258068 & -1.458210 & 0.460702 \\
\hline C & 3.505217 & -1.682496 & -0.062495 \\
\hline C & 3.560490 & -2.094690 & -1.359860 \\
\hline$S$ & 1.966689 & -2.184535 & -2.000349 \\
\hline $\mathrm{H}$ & 4.446592 & -2.327741 & -1.931614 \\
\hline C & 4.714649 & -1.414002 & 0.760044 \\
\hline $\mathrm{O}$ & 5.856086 & -1.520283 & 0.328654 \\
\hline $\mathrm{N}$ & 4.424649 & -1.017254 & 2.029259 \\
\hline $\mathrm{H}$ & 5.171509 & -0.627283 & 2.582834 \\
\hline
\end{tabular}




\begin{tabular}{|c|c|c|c|}
\hline $\mathrm{H}$ & 3.460145 & -0.799782 & 2.242652 \\
\hline C & -0.066461 & -1.314586 & -0.301977 \\
\hline $\mathrm{N}$ & -0.412655 & -1.006039 & 1.056708 \\
\hline C & -0.824149 & -1.907815 & 1.986034 \\
\hline 0 & -1.182629 & -3.048408 & 1.731562 \\
\hline C & -0.824936 & -1.377694 & 3.413826 \\
\hline $\mathrm{H}$ & -0.988859 & -0.297781 & 3.459225 \\
\hline $\mathrm{H}$ & -1.600936 & -1.893353 & 3.980376 \\
\hline $\mathrm{H}$ & 0.144539 & -1.600734 & 3.870816 \\
\hline C & -1.082696 & -2.097143 & -1.095904 \\
\hline $\mathrm{H}$ & -1.082528 & -3.160636 & -0.835646 \\
\hline $\mathrm{H}$ & -0.808470 & -1.979657 & -2.151930 \\
\hline C & -2.481647 & -1.527148 & -0.878022 \\
\hline$C$ & -2.526901 & -0.020508 & -0.794468 \\
\hline $\mathrm{N}$ & -1.584940 & 0.819475 & -0.926360 \\
\hline C & -0.248923 & 0.384316 & -1.380711 \\
\hline C & 0.778724 & 1.213750 & -0.666884 \\
\hline C & 0.633318 & 2.051681 & 0.394881 \\
\hline $\mathrm{O}$ & 1.875413 & 2.493164 & 0.767347 \\
\hline$C$ & 2.708939 & 1.884113 & -0.100445 \\
\hline $\mathrm{N}$ & 2.127641 & 1.131640 & -0.976640 \\
\hline C & 4.141774 & 2.063104 & 0.061528 \\
\hline C & 5.121613 & 1.374913 & -0.580181 \\
\hline $\mathrm{O}$ & 6.311941 & 1.839288 & -0.121036 \\
\hline$C$ & 5.985774 & 2.784387 & 0.781569 \\
\hline $\mathrm{N}$ & 4.720968 & 2.969900 & 0.942412 \\
\hline $\mathrm{H}$ & 6.803665 & 3.290181 & 1.272943 \\
\hline $\mathrm{H}$ & 5.131071 & 0.560869 & -1.286503 \\
\hline $\mathrm{H}$ & -0.213901 & 2.453294 & 0.926341 \\
\hline $\mathrm{O}$ & -0.113147 & 0.103205 & -2.590724 \\
\hline$C$ & -3.849463 & 0.560248 & -0.451709 \\
\hline $\mathrm{N}$ & -4.936844 & -0.108168 & -0.211991 \\
\hline C & -5.978141 & 0.740470 & 0.082572 \\
\hline C & -5.678763 & 2.069635 & 0.064911 \\
\hline$S$ & -4.025929 & 2.298219 & -0.337117 \\
\hline $\mathrm{H}$ & -6.360898 & 2.882446 & 0.268519 \\
\hline$C$ & -7.329899 & 0.199718 & 0.403381 \\
\hline 0 & -8.278075 & 0.920876 & 0.671148 \\
\hline $\mathrm{N}$ & -7.389198 & -1.155152 & 0.362938 \\
\hline $\mathrm{H}$ & -6.553760 & -1.689302 & 0.17045 \\
\hline $\mathrm{H}$ & -8.254774 & -1.611076 & 0.603658 \\
\hline $\mathrm{H}$ & -3.170112 & -1.849679 & -1.668265 \\
\hline $\mathrm{H}$ & -2.897669 & -1.911763 & 0.061684 \\
\hline $\mathrm{H}$ & -0.008721 & -0.141339 & 1.405031 \\
\hline \multicolumn{4}{|c|}{4 Pdt1a (exo) } \\
\hline
\end{tabular}




\begin{tabular}{|c|c|c|c|}
\hline C & 1.377377 & -1.555983 & -0.725250 \\
\hline N & 2.284796 & -1.777285 & 0.181482 \\
\hline C & 3.521442 & -1.929373 & -0.395581 \\
\hline C & 3.549689 & -1.879168 & -1.758006 \\
\hline$S$ & 1.978191 & -1.561205 & -2.363250 \\
\hline $\mathrm{H}$ & 4.422570 & -1.971998 & -2.388465 \\
\hline C & 4.724566 & -2.082935 & 0.460485 \\
\hline O & 5.866646 & -1.964544 & 0.032934 \\
\hline N & 4.432516 & -2.358416 & 1.759546 \\
\hline $\mathrm{H}$ & 5.180313 & -2.331662 & 2.434452 \\
\hline H & 3.466307 & -2.311136 & 2.052983 \\
\hline C & -0.034602 & -1.141083 & -0.418214 \\
\hline N & -0.202209 & -1.003086 & 1.019182 \\
\hline C & -0.170007 & -2.035938 & 1.905036 \\
\hline O & -0.315509 & -3.209758 & 1.606425 \\
\hline C & 0.053878 & -1.598828 & 3.346260 \\
\hline $\mathrm{H}$ & -0.522340 & -0.702566 & 3.593099 \\
\hline $\mathrm{H}$ & -0.225642 & -2.415264 & 4.011790 \\
\hline $\mathrm{H}$ & 1.115366 & -1.367733 & 3.486420 \\
\hline C & -1.085566 & -2.056255 & -1.050238 \\
\hline $\mathrm{H}$ & -0.922088 & -3.096143 & -0.764384 \\
\hline $\mathrm{H}$ & -0.965720 & -1.934305 & -2.130301 \\
\hline C & -2.475287 & -1.592731 & -0.628428 \\
\hline C & -2.585836 & -0.084811 & -0.586328 \\
\hline$N$ & -1.658264 & 0.771540 & -0.712760 \\
\hline C & -0.276856 & 0.297188 & -1.133892 \\
\hline C & 0.675330 & 1.307218 & -0.478570 \\
\hline C & 0.421713 & 2.426089 & 0.246965 \\
\hline 0 & 1.616600 & 3.008228 & 0.588097 \\
\hline C & 2.540567 & 2.188525 & 0.048249 \\
\hline N & 2.055228 & 1.180966 & -0.597595 \\
\hline C & 3.953644 & 2.442664 & 0.276897 \\
\hline C & 4.979514 & 1.591764 & 0.007042 \\
\hline 0 & 6.129744 & 2.217578 & 0.376932 \\
\hline C & 5.732563 & 3.411929 & 0.855912 \\
\hline$N$ & 4.460367 & 3.613003 & 0.829916 \\
\hline $\mathrm{H}$ & 6.507163 & 4.076142 & 1.209687 \\
\hline $\mathrm{H}$ & 5.057049 & 0.592483 & -0.396400 \\
\hline $\mathrm{H}$ & -0.477301 & 2.930726 & 0.558001 \\
\hline O & -0.167144 & 0.209763 & -2.423743 \\
\hline C & -3.938533 & 0.456984 & -0.316870 \\
\hline$N$ & -5.006317 & -0.240972 & -0.069312 \\
\hline C & -6.087155 & 0.580964 & 0.154207 \\
\hline C & -5.838607 & 1.917947 & 0.075389 \\
\hline S & -4.183991 & 2.190713 & -0.294207 \\
\hline
\end{tabular}




$\begin{array}{lrrr}\text { H } & -6.557190 & 2.712367 & 0.216368 \\ \mathrm{C} & -7.426172 & 0.003462 & 0.461883 \\ \mathrm{O} & -8.411031 & 0.696056 & 0.665875 \\ \mathrm{~N} & -7.430242 & -1.353440 & 0.490619 \\ \mathrm{H} & -6.574449 & -1.861344 & 0.318241 \\ \mathrm{H} & -8.291166 & -1.833881 & 0.697354 \\ \mathrm{H} & -3.250817 & -1.987845 & -1.293782 \\ \mathrm{H} & -2.713079 & -1.967462 & 0.375952 \\ \mathrm{H} & 0.068289 & -0.093020 & 1.376894\end{array}$

\section{Bisthiazoles}

$\begin{array}{lrrr}\text { 1 Diene (iminol) } & & \\ \mathrm{C} & -0.158834 & 0.920509 & 0.045329 \\ \mathrm{C} & -1.321569 & 0.007991 & 0.050606 \\ \mathrm{O} & -0.478009 & 2.223765 & 0.005592 \\ \mathrm{C} & 2.345383 & 2.543084 & 0.115663 \\ \mathrm{C} & 2.192776 & 1.209911 & 0.072764 \\ \mathrm{C} & 3.390303 & 0.342342 & 0.025806 \\ \mathrm{~N} & 1.019296 & 0.443702 & 0.075425 \\ \mathrm{~N} & 4.624805 & 0.746338 & 0.010918 \\ \mathrm{C} & 5.488082 & -0.320606 & -0.036843 \\ \mathrm{C} & 4.908119 & -1.553316 & -0.059329 \\ \mathrm{~S} & 3.201179 & -1.394933 & -0.019106 \\ \mathrm{C} & 6.967837 & -0.117770 & -0.062056 \\ \mathrm{O} & 7.745312 & -1.055407 & -0.103497 \\ \mathrm{~N} & 7.338393 & 1.186111 & -0.035117 \\ \mathrm{C} & -1.282300 & -1.354824 & 0.092724 \\ \mathrm{C} & -3.491458 & -0.356248 & 0.019473 \\ \mathrm{~N} & -2.574071 & 0.567940 & 0.009394 \\ \mathrm{C} & -4.928963 & -0.108794 & -0.017247 \\ \mathrm{~N} & -5.788033 & -1.183611 & 0.004441 \\ \mathrm{C} & -7.015632 & -0.777229 & -0.034535 \\ \mathrm{C} & -5.518906 & 1.121996 & -0.073401 \\ \mathrm{H} & -1.453667 & 2.282314 & -0.019387 \\ \mathrm{H} & 3.351921 & 2.945433 & 0.115811 \\ \mathrm{H} & 1.507802 & 3.223040 & 0.153266 \\ \mathrm{H} & 5.419558 & -2.504167 & -0.096552 \\ \mathrm{H} & 8.320591 & 1.412438 & -0.047140 \\ \mathrm{H} & 6.638868 & 1.912361 & 0.001078 \\ \mathrm{H} & -0.402323 & -1.980731 & 0.128869 \\ \mathrm{H} & -7.871914 & -1.440328 & -0.027558 \\ \mathrm{H} & -5.034189 & 2.086638 & -0.098901 \\ \mathrm{~S} & -2.877474 & -1.982386 & 0.081262\end{array}$




\begin{tabular}{|c|c|c|c|c|}
\hline$S$ & -7.224131 & 0.942976 & -0.100617 & \\
\hline \multicolumn{4}{|c|}{2 Diene (amide) } & Diene (amide) \\
\hline C & -0.266694 & -2.408953 & -0.009001 & \\
\hline C & 1.062346 & -1.770699 & -0.113584 & \\
\hline $\mathrm{O}$ & -0.386677 & -3.616006 & 0.113138 & \\
\hline C & -3.208219 & -3.068331 & 0.082591 & \\
\hline C & -2.675879 & -1.841047 & 0.028153 & \\
\hline C & -3.495741 & -0.612456 & 0.040715 & \\
\hline$N$ & -1.314309 & -1.526067 & -0.050632 & \\
\hline$N$ & -2.968350 & 0.577446 & 0.057828 & \\
\hline C & -3.937418 & 1.551161 & 0.069504 & \\
\hline C & -5.220803 & 1.099453 & 0.058705 & \\
\hline$S$ & -5.238307 & -0.616751 & 0.030460 & \\
\hline C & -3.591158 & 3.005259 & 0.097522 & \\
\hline $\mathrm{O}$ & -4.455344 & 3.862919 & 0.100047 & \\
\hline$N$ & -2.259330 & 3.255023 & 0.117882 & \\
\hline C & 2.202020 & -2.416835 & 0.157909 & \\
\hline $\mathrm{O}$ & 3.349989 & -1.719666 & 0.056084 & \\
\hline C & 3.090297 & -0.373905 & -0.208856 & \\
\hline C & 4.080534 & 0.531912 & -0.099870 & \\
\hline C & 6.227587 & 1.714197 & 0.289602 & \\
\hline $\mathrm{O}$ & 5.263970 & 2.506037 & -0.063225 & \\
\hline C & 4.084459 & 1.940526 & -0.300984 & \\
\hline $\mathrm{H}$ & -4.285701 & -3.179466 & 0.139318 & \\
\hline $\mathrm{H}$ & -2.592126 & -3.954044 & 0.077489 & \\
\hline $\mathrm{H}$ & -6.119658 & 1.698844 & 0.064761 & \\
\hline $\mathrm{H}$ & -1.950120 & 4.214055 & 0.157516 & \\
\hline $\mathrm{H}$ & -1.589970 & 2.500717 & 0.140252 & \\
\hline $\mathrm{H}$ & 2.302612 & -3.452592 & 0.452618 & \\
\hline $\mathrm{H}$ & 7.207527 & 2.124246 & 0.464816 & \\
\hline $\mathrm{H}$ & 3.294468 & 2.602059 & -0.610767 & \\
\hline $\mathrm{H}$ & -1.117771 & -0.530934 & -0.032097 & \\
\hline$S$ & 1.391058 & -0.098475 & -0.644567 & \\
\hline$S$ & 5.744822 & 0.056746 & 0.368341 & \\
\hline \multicolumn{5}{|c|}{3 Diene (iminol, cis bisoxazole) } \\
\hline C & -0.149265 & 0.924069 & 0.002279 & \\
\hline C & -1.314293 & 0.012988 & 0.003137 & \\
\hline $\mathrm{O}$ & -0.467168 & 2.226023 & -0.000600 & \\
\hline C & 2.358831 & 2.538293 & 0.005246 & \\
\hline C & 2.202985 & 1.204782 & 0.003537 & \\
\hline C & 3.398528 & 0.333251 & 0.001321 & \\
\hline N & 1.027399 & 0.441712 & 0.004153 & \\
\hline N & 4.634493 & 0.732741 & 0.000038 & \\
\hline C & 5.494889 & -0.337642 & -0.002025 & \\
\hline
\end{tabular}




\begin{tabular}{|c|c|c|c|}
\hline C & 4.911411 & -1.568810 & -0.002372 \\
\hline$S$ & 3.204466 & -1.404389 & 0.000138 \\
\hline C & 6.975519 & -0.139672 & -0.003967 \\
\hline 0 & 7.750571 & -1.080289 & -0.006775 \\
\hline$N$ & 7.349677 & 1.163397 & -0.002149 \\
\hline C & -1.281337 & -1.349096 & 0.006373 \\
\hline C & -3.493060 & -0.319440 & 0.001463 \\
\hline$N$ & -2.560547 & 0.585183 & 0.000413 \\
\hline C & -4.927449 & -0.022332 & -0.000998 \\
\hline$N$ & -5.332878 & 1.294120 & 0.000615 \\
\hline C & -6.623015 & 1.363689 & -0.002019 \\
\hline C & -5.935073 & -0.948045 & -0.004974 \\
\hline $\mathrm{H}$ & -1.444380 & 2.291834 & -0.001975 \\
\hline $\mathrm{H}$ & 3.366519 & 2.937820 & 0.005034 \\
\hline $\mathrm{H}$ & 1.522742 & 3.221130 & 0.007026 \\
\hline $\mathrm{H}$ & 5.420357 & -2.521709 & -0.003928 \\
\hline $\mathrm{H}$ & 8.332621 & 1.386747 & -0.005643 \\
\hline $\mathrm{H}$ & 6.651874 & 1.892229 & -0.002267 \\
\hline $\mathrm{H}$ & -0.410017 & -1.987868 & 0.008838 \\
\hline $\mathrm{H}$ & -7.176567 & 2.294821 & -0.001375 \\
\hline $\mathrm{H}$ & -5.860771 & -2.026893 & -0.007220 \\
\hline S & -2.885708 & -1.957153 & 0.006298 \\
\hline S & -7.456798 & -0.158849 & -0.006622 \\
\hline \multicolumn{4}{|c|}{4 TS1a (exo) } \\
\hline C & -0.577987 & 1.795463 & 0.035291 \\
\hline $\mathrm{N}$ & -1.312619 & 1.280931 & 0.995964 \\
\hline C & -2.639238 & 1.581318 & 0.807707 \\
\hline C & -2.943158 & 2.313959 & -0.297616 \\
\hline$S$ & -1.509819 & 2.660800 & -1.178708 \\
\hline C & 0.862578 & 1.720626 & -0.012627 \\
\hline$N$ & 1.445377 & 0.989736 & 1.013739 \\
\hline C & 0.169931 & -0.701644 & -1.631315 \\
\hline C & 2.742494 & 1.084911 & 1.478465 \\
\hline $\mathrm{O}$ & 3.519477 & 1.954600 & 1.125194 \\
\hline C & -0.928383 & -1.320299 & -0.885141 \\
\hline $\mathrm{O}$ & -0.197153 & 0.118423 & -2.632548 \\
\hline C & 1.652894 & 2.304254 & -1.010950 \\
\hline C & 2.439169 & 1.007412 & -2.232758 \\
\hline C & 2.473174 & -0.254212 & -1.617578 \\
\hline C & 3.705619 & -0.723983 & -0.992817 \\
\hline$N$ & 1.380801 & -0.991383 & -1.293525 \\
\hline $\mathrm{N}$ & 4.713522 & 0.038941 & -0.685671 \\
\hline C & 5.681730 & -0.670838 & -0.022918 \\
\hline C & 5.441178 & -2.003370 & 0.135838 \\
\hline$S$ & 3.900564 & -2.403315 & -0.519102 \\
\hline
\end{tabular}




\begin{tabular}{|c|c|c|c|}
\hline C & 6.837661 & 0.032289 & 0.616247 \\
\hline 0 & 7.842621 & -0.562219 & 0.966899 \\
\hline $\mathrm{N}$ & 6.614715 & 1.357836 & 0.798373 \\
\hline C & -3.702652 & 1.100789 & 1.742361 \\
\hline $\mathrm{N}$ & -3.242576 & 0.331573 & 2.757374 \\
\hline 0 & -4.877878 & 1.385825 & 1.573974 \\
\hline C & -0.791728 & -2.173455 & 0.174635 \\
\hline C & -3.051800 & -1.445139 & -0.326677 \\
\hline $\mathrm{N}$ & -2.208696 & -0.914767 & -1.165479 \\
\hline C & -4.478452 & -1.156752 & -0.273865 \\
\hline $\mathrm{N}$ & -5.213128 & -1.645249 & 0.781481 \\
\hline C & -6.431041 & -1.213040 & 0.709484 \\
\hline C & -5.155000 & -0.364915 & -1.157750 \\
\hline C & 3.131316 & -0.019187 & 2.433230 \\
\hline $\mathrm{H}$ & -3.924908 & 2.639804 & -0.608575 \\
\hline $\mathrm{H}$ & 0.816970 & 0.352308 & 1.491832 \\
\hline $\mathrm{H}$ & -1.173103 & 0.189316 & -2.605819 \\
\hline $\mathrm{H}$ & 1.129451 & 2.961608 & -1.700571 \\
\hline $\mathrm{H}$ & 2.621293 & 2.665445 & -0.688877 \\
\hline $\mathrm{H}$ & 3.410351 & 1.459869 & -2.406952 \\
\hline $\mathrm{H}$ & 1.705271 & 1.155994 & -3.013675 \\
\hline $\mathrm{H}$ & 6.080090 & -2.722626 & 0.627488 \\
\hline $\mathrm{H}$ & 7.296544 & 1.871706 & 1.336505 \\
\hline $\mathrm{H}$ & 5.680918 & 1.738215 & 0.678321 \\
\hline $\mathrm{H}$ & -2.270788 & 0.059707 & 2.779820 \\
\hline $\mathrm{H}$ & -3.916669 & -0.152099 & 3.332018 \\
\hline $\mathrm{H}$ & 0.127318 & -2.600155 & 0.549938 \\
\hline $\mathrm{H}$ & -7.200312 & -1.451414 & 1.433271 \\
\hline $\mathrm{H}$ & -4.763321 & 0.120782 & -2.039356 \\
\hline $\mathrm{H}$ & 3.227010 & -0.958180 & 1.875225 \\
\hline $\mathrm{H}$ & 4.093108 & 0.229237 & 2.881358 \\
\hline $\mathrm{H}$ & 2.382265 & -0.161907 & 3.218099 \\
\hline$S$ & -2.330090 & -2.502002 & 0.854806 \\
\hline$S$ & -6.778757 & -0.197301 & -0.647713 \\
\hline \multicolumn{4}{|c|}{5 TS1b (endo) } \\
\hline C & 0.123295 & -0.164153 & 1.585906 \\
\hline $\mathrm{N}$ & -1.097847 & -0.645375 & 1.620854 \\
\hline C & -1.082356 & -2.013468 & 1.725910 \\
\hline C & 0.148094 & -2.595143 & 1.759213 \\
\hline$S$ & 1.371403 & -1.387035 & 1.668488 \\
\hline C & 0.408274 & 1.250782 & 1.485764 \\
\hline $\mathrm{N}$ & -0.747333 & 2.020259 & 1.359744 \\
\hline C & 0.241868 & 0.933448 & -1.368399 \\
\hline C & -0.836164 & 3.385389 & 1.265679 \\
\hline 0 & 0.119732 & 4.136664 & 1.339950 \\
\hline
\end{tabular}




\begin{tabular}{|c|c|c|c|}
\hline C & -0.931051 & 0.059539 & -1.451896 \\
\hline 0 & -0.022757 & 2.250269 & -1.381464 \\
\hline C & 1.704465 & 1.773047 & 1.568542 \\
\hline C & 2.505049 & 2.246453 & -0.144400 \\
\hline C & 2.527199 & 1.055826 & -0.883228 \\
\hline C & 3.742503 & 0.246018 & -0.901204 \\
\hline$N$ & 1.420581 & 0.407826 & -1.322968 \\
\hline N & 4.884498 & 0.586785 & -0.369835 \\
\hline C & 5.820664 & -0.399450 & -0.553610 \\
\hline C & 5.400963 & -1.500041 & -1.239086 \\
\hline$S$ & 3.750855 & -1.323825 & -1.678476 \\
\hline C & 7.213423 & -0.252511 & -0.033180 \\
\hline 0 & 8.053052 & -1.121690 & -0.189381 \\
\hline$N$ & 7.430993 & 0.917470 & 0.616729 \\
\hline C & -2.353506 & -2.800760 & 1.752139 \\
\hline$N$ & -3.476031 & -2.035494 & 1.827102 \\
\hline 0 & -2.352065 & -4.017572 & 1.711142 \\
\hline C & -0.918267 & -1.300805 & -1.587639 \\
\hline C & -3.089962 & -0.295610 & -1.220472 \\
\hline$N$ & -2.166246 & 0.625851 & -1.246940 \\
\hline C & -4.508551 & -0.034150 & -0.992278 \\
\hline N & -5.352131 & -1.090371 & -0.726853 \\
\hline C & -6.562822 & -0.665113 & -0.551308 \\
\hline C & -5.096444 & 1.199926 & -1.013642 \\
\hline C & -2.252391 & 3.898437 & 1.083382 \\
\hline $\mathrm{H}$ & 0.367938 & -3.650111 & 1.832085 \\
\hline $\mathrm{H}$ & -1.597717 & 1.470444 & 1.289106 \\
\hline $\mathrm{H}$ & -0.994610 & 2.348025 & -1.359335 \\
\hline $\mathrm{H}$ & 1.790210 & 2.787220 & 1.938612 \\
\hline $\mathrm{H}$ & 2.464476 & 1.083554 & 1.928106 \\
\hline $\mathrm{H}$ & 3.472388 & 2.599201 & 0.201251 \\
\hline $\mathrm{H}$ & 1.787563 & 3.016809 & -0.391040 \\
\hline H & 5.994044 & -2.368148 & -1.487546 \\
\hline $\mathrm{H}$ & 8.354174 & 1.109928 & 0.973097 \\
\hline $\mathrm{H}$ & 6.698080 & 1.608072 & 0.678611 \\
\hline $\mathrm{H}$ & -3.392897 & -1.037214 & 1.697524 \\
\hline $\mathrm{H}$ & -4.358838 & -2.478237 & 1.615774 \\
\hline H & -0.052914 & -1.935566 & -1.715932 \\
\hline $\mathrm{H}$ & -7.403106 & -1.311747 & -0.329799 \\
\hline $\mathrm{H}$ & -4.628601 & 2.150954 & -1.222106 \\
\hline $\mathrm{H}$ & -2.227715 & 4.732385 & 0.379861 \\
\hline $\mathrm{H}$ & -2.940505 & 3.128483 & 0.723540 \\
\hline H & -2.620033 & 4.280629 & 2.040082 \\
\hline$S$ & -2.510211 & -1.912355 & -1.464389 \\
\hline$S$ & -6.774344 & 1.048796 & -0.691613 \\
\hline
\end{tabular}




\begin{tabular}{|c|c|c|c|}
\hline \multicolumn{4}{|c|}{6 Pdt (exo) } \\
\hline C & -1.014970 & 1.757843 & -0.452481 \\
\hline & -1.972773 & 1.570644 & 0.403512 \\
\hline 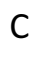 & -3.184179 & 1.938937 & -0.127784 \\
\hline 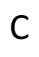 & -3.148620 & 2.448551 & -1.390844 \\
\hline & -1.533218 & 2.449093 & -1.965048 \\
\hline 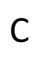 & 0.395033 & 1.257265 & -0.226840 \\
\hline$\sqrt{ }$ & 0.650980 & 1.153737 & 1.201218 \\
\hline & 0.531012 & -0.199609 & -0.846924 \\
\hline $\mathcal{C}$ & 0.611721 & 2.268428 & 2.011111 \\
\hline 0 & 0.689827 & 3.402418 & 1.581584 \\
\hline C & -0.474487 & -1.141591 & -0.221397 \\
\hline כ & 0.306741 & -0.123153 & -2.229948 \\
\hline  & 1.455146 & 2.106486 & -0.940590 \\
\hline C & 2.838476 & 1.563061 & -0.608505 \\
\hline C & 2.859958 & 0.056478 & -0.567609 \\
\hline C & 4.184153 & -0.572697 & -0.380419 \\
\hline v & 1.867462 & -0.739127 & -0.641010 \\
\hline J & 5.297449 & 0.086986 & -0.252167 \\
\hline$C$ & 6.351158 & -0.773865 & -0.080913 \\
\hline$c$ & 6.031330 & -2.101073 & -0.080735 \\
\hline$S$ & 4.346586 & -2.305423 & -0.304319 \\
\hline[ & 7.749130 & -0.274084 & 0.093049 \\
\hline O & 8.683959 & -1.039608 & 0.245644 \\
\hline$V$ & 7.854578 & 1.076410 & 0.064822 \\
\hline C & -4.460012 & 1.682032 & 0.604517 \\
\hline$V$ & -4.286621 & 1.144970 & 1.835576 \\
\hline O & -5.545678 & 1.908436 & 0.095181 \\
\hline$C$ & -0.265829 & -2.004158 & 0.811970 \\
\hline C & -2.548976 & -1.844986 & 0.007116 \\
\hline V & -1.763087 & -1.076080 & -0.688562 \\
\hline C & -3.998056 & -1.908508 & -0.148057 \\
\hline 小 & -4.711675 & -2.811017 & 0.606193 \\
\hline C & -5.980045 & -2.670329 & 0.383529 \\
\hline C & -4.738135 & -1.077820 & -0.942758 \\
\hline C & 0.461916 & 1.959278 & 3.486437 \\
\hline $\mathrm{H}$ & -3.987149 & 2.802734 & -1.973238 \\
\hline H & 0.297898 & 0.302216 & 1.625686 \\
\hline $\mathrm{H}$ & -0.625526 & -0.360336 & -2.381151 \\
\hline H & 1.272663 & 2.027915 & -2.016574 \\
\hline $\mathrm{H}$ & 1.364196 & 3.148302 & -0.635534 \\
\hline $\mathrm{H}$ & 3.169170 & 1.917002 & 0.375614 \\
\hline $\mathrm{H}$ & 3.591479 & 1.906359 & -1.324047 \\
\hline $\mathrm{H}$ & 6.719902 & -2.925827 & 0.036367 \\
\hline $\mathrm{H}$ & 8.766542 & 1.493500 & 0.170306 \\
\hline
\end{tabular}




$\begin{array}{lrrr}\mathrm{H} & 7.037500 & 1.652826 & -0.069664 \\ \mathrm{H} & -3.359258 & 0.915979 & 2.161460 \\ \mathrm{H} & -5.100523 & 0.873749 & 2.365883 \\ \mathrm{H} & 0.676235 & -2.254535 & 1.279653 \\ \mathrm{H} & -6.744277 & -3.273362 & 0.858419 \\ \mathrm{H} & -4.384416 & -0.276473 & -1.576036 \\ \mathrm{H} & -0.601165 & 1.812622 & 3.705390 \\ \mathrm{H} & 1.003268 & 1.054573 & 3.774558 \\ \mathrm{H} & 0.821922 & 2.809890 & 4.064010 \\ \mathrm{~S} & -1.753674 & -2.748982 & 1.263910 \\ \mathrm{~S} & -6.402556 & -1.424399 & -0.743237\end{array}$

\section{Second step - loss of water}

1 Oxazole product

$\begin{array}{lrrr}\text { C } & 1.300727 & -1.558630 & -0.634481 \\ \text { N } & 2.063743 & -1.836094 & 0.378305 \\ \text { C } & 3.366214 & -1.961899 & -0.032304 \\ \text { C } & 3.584461 & -1.819714 & -1.371734 \\ \text { S } & 2.103810 & -1.513896 & -2.171080 \\ \text { C } & -0.122399 & -1.088074 & -0.441952 \\ \text { N } & -0.687438 & -1.664065 & 0.777442 \\ \text { C } & -0.211133 & 0.440673 & -0.250110 \\ \text { C } & -1.129435 & -2.988482 & 0.827255 \\ \text { O } & -1.513574 & -3.584254 & -0.155070 \\ \text { C } & 0.900929 & 1.318994 & -0.125573 \\ \text { C } & -0.998353 & -1.311914 & -1.698650 \\ \text { C } & -2.433905 & -0.905429 & -1.407200 \\ \text { C } & -2.491362 & 0.315246 & -0.542463 \\ \text { C } & -3.764541 & 0.809963 & -0.110617 \\ \text { N } & -1.418143 & 0.989799 & -0.177003 \\ \text { N } & -4.905708 & 0.216109 & -0.398611 \\ \text { C } & -5.938056 & 0.878550 & 0.156218 \\ \text { C } & -5.595648 & 2.007358 & 0.884866 \\ \text { S } & -3.922299 & 2.240929 & 0.872070 \\ \text { C } & -7.373223 & 0.452153 & 0.011238 \\ \text { O } & -8.247132 & 1.106615 & 0.542999 \\ \text { N } & -7.554896 & -0.663145 & -0.725203 \\ \text { C } & 4.489483 & -2.143302 & 0.936876 \\ \text { N } & 4.131715 & -2.618903 & 2.147158 \\ \text { O } & 5.630118 & -1.841431 & 0.619379 \\ \text { C } & 0.806912 & 2.685769 & 0.104258 \\ \text { O } & 2.029310 & 3.173447 & 0.176979 \\ \text { C } & 2.875968 & 2.093851 & -0.009705\end{array}$




\begin{tabular}{|c|c|c|c|}
\hline $\mathrm{N}$ & 2.245587 & 0.987487 & -0.192810 \\
\hline C & 4.296226 & 2.336732 & 0.041992 \\
\hline$N$ & 4.827618 & 3.614440 & 0.107280 \\
\hline C & 6.098033 & 3.410292 & 0.137386 \\
\hline $\mathrm{O}$ & 6.455168 & 2.106020 & 0.101119 \\
\hline C & 5.302309 & 1.413961 & 0.040829 \\
\hline C & -1.118305 & -3.583465 & 2.215270 \\
\hline $\mathrm{H}$ & 4.527331 & -1.906303 & -1.893753 \\
\hline $\mathrm{H}$ & -0.140664 & -1.401914 & 1.593272 \\
\hline $\mathrm{H}$ & -0.583130 & -0.698087 & -2.507947 \\
\hline $\mathrm{H}$ & -0.953663 & -2.357967 & -1.995992 \\
\hline $\mathrm{H}$ & -2.955430 & -1.711439 & -0.873959 \\
\hline $\mathrm{H}$ & -3.009717 & -0.722782 & -2.320756 \\
\hline $\mathrm{H}$ & -6.287967 & 2.665564 & 1.394316 \\
\hline $\mathrm{H}$ & -8.496449 & -1.002152 & -0.863093 \\
\hline $\mathrm{H}$ & -6.778532 & -1.156221 & -1.139613 \\
\hline $\mathrm{H}$ & 3.175043 & -2.865149 & 2.348683 \\
\hline $\mathrm{H}$ & 4.849471 & -2.771002 & 2.841326 \\
\hline $\mathrm{H}$ & -0.022531 & 3.363166 & 0.244647 \\
\hline $\mathrm{H}$ & 6.896818 & 4.134908 & 0.186722 \\
\hline $\mathrm{H}$ & 5.367543 & 0.331908 & 0.026794 \\
\hline $\mathrm{H}$ & -0.089948 & -3.853981 & 2.477694 \\
\hline $\mathrm{H}$ & -1.488978 & -2.875940 & 2.961474 \\
\hline $\mathrm{H}$ & -1.731247 & -4.483490 & 2.216780 \\
\hline \multicolumn{4}{|c|}{2 Thiazole product } \\
\hline C & -1.004955 & 1.636240 & -0.631506 \\
\hline $\mathrm{N}$ & -1.744940 & 2.020308 & 0.362107 \\
\hline C & -3.030218 & 2.240849 & -0.064551 \\
\hline C & -3.254585 & 2.058133 & -1.398099 \\
\hline$S$ & -1.802451 & 1.592239 & -2.172270 \\
\hline C & 0.399735 & 1.118999 & -0.429987 \\
\hline $\mathrm{N}$ & 0.982046 & 1.692871 & 0.782282 \\
\hline C & 0.475752 & -0.409332 & -0.233853 \\
\hline C & 1.383828 & 3.029236 & 0.827438 \\
\hline $\mathrm{O}$ & 1.703035 & 3.644685 & -0.165941 \\
\hline C & -0.632477 & -1.297073 & -0.112092 \\
\hline C & 1.275933 & 1.332968 & -1.691498 \\
\hline C & 2.711431 & 0.934937 & -1.396200 \\
\hline C & 2.763368 & -0.283673 & -0.528194 \\
\hline C & 4.039783 & -0.783945 & -0.100175 \\
\hline$N$ & 1.692942 & -0.948478 & -0.153498 \\
\hline$N$ & 5.180985 & -0.200979 & -0.401529 \\
\hline C & 6.214904 & -0.867630 & 0.151122 \\
\hline C & 5.871401 & -1.986344 & 0.890372 \\
\hline S & 4.194040 & -2.207513 & 0.892555 \\
\hline
\end{tabular}




$\begin{array}{lrrr}\text { C } & 7.650142 & -0.449915 & -0.010946 \\ \text { O } & 8.527952 & -1.102598 & 0.516906 \\ \text { N } & 7.829427 & 0.658659 & -0.758910 \\ \text { C } & -4.136276 & 2.584450 & 0.881055 \\ \text { N } & -3.737905 & 3.062874 & 2.077542 \\ \text { O } & -5.299333 & 2.401461 & 0.555686 \\ \text { C } & -0.440979 & -2.673855 & 0.058386 \\ \text { C } & -2.742496 & -1.918680 & -0.013884 \\ \text { N } & -1.955654 & -0.906226 & -0.144131 \\ \text { C } & -4.194901 & -1.926877 & 0.024306 \\ \text { N } & -4.808227 & -3.154447 & 0.121909 \\ \text { C } & -6.094161 & -3.006423 & 0.161874 \\ \text { C } & -5.026182 & -0.838121 & -0.006486 \\ \text { C } & 1.417085 & 3.612189 & 2.220169 \\ \text { H } & -4.184738 & 2.203526 & -1.929954 \\ \text { H } & 0.473520 & 1.405271 & 1.613681 \\ \text { H } & 0.863005 & 0.709432 & -2.494640 \\ \text { H } & 1.224862 & 2.376040 & -1.997661 \\ \text { H } & 3.228938 & 1.743041 & -0.862375 \\ \text { H } & 3.290769 & 0.751267 & -2.307090 \\ \text { H } & 6.562198 & -2.645476 & 1.400286 \\ \text { H } & 8.770877 & 0.992383 & -0.908998 \\ \text { H } & 7.050532 & 1.151070 & -1.169243 \\ \text { H } & -2.759863 & 3.187137 & 2.288413 \\ \text { H } & -4.439019 & 3.312610 & 2.760158 \\ \text { H } & 0.512829 & -3.178784 & 0.132134 \\ \text { H } & -6.793397 & -3.830242 & 0.236056 \\ \text { H } & -4.789114 & 0.216474 & -0.060168 \\ \text { H } & 0.394353 & 3.856038 & 2.526855 \\ \text { H } & 1.834632 & 2.907856 & 2.944216 \\ \text { H } & 2.007763 & 4.526883 & 2.204660 \\ \text { S } & -1.908666 & -3.483889 & 0.163545 \\ \text { S } & -6.648477 & -1.365950 & 0.090328\end{array}$




\section{Peptide Characterization}

\section{Compound S25}
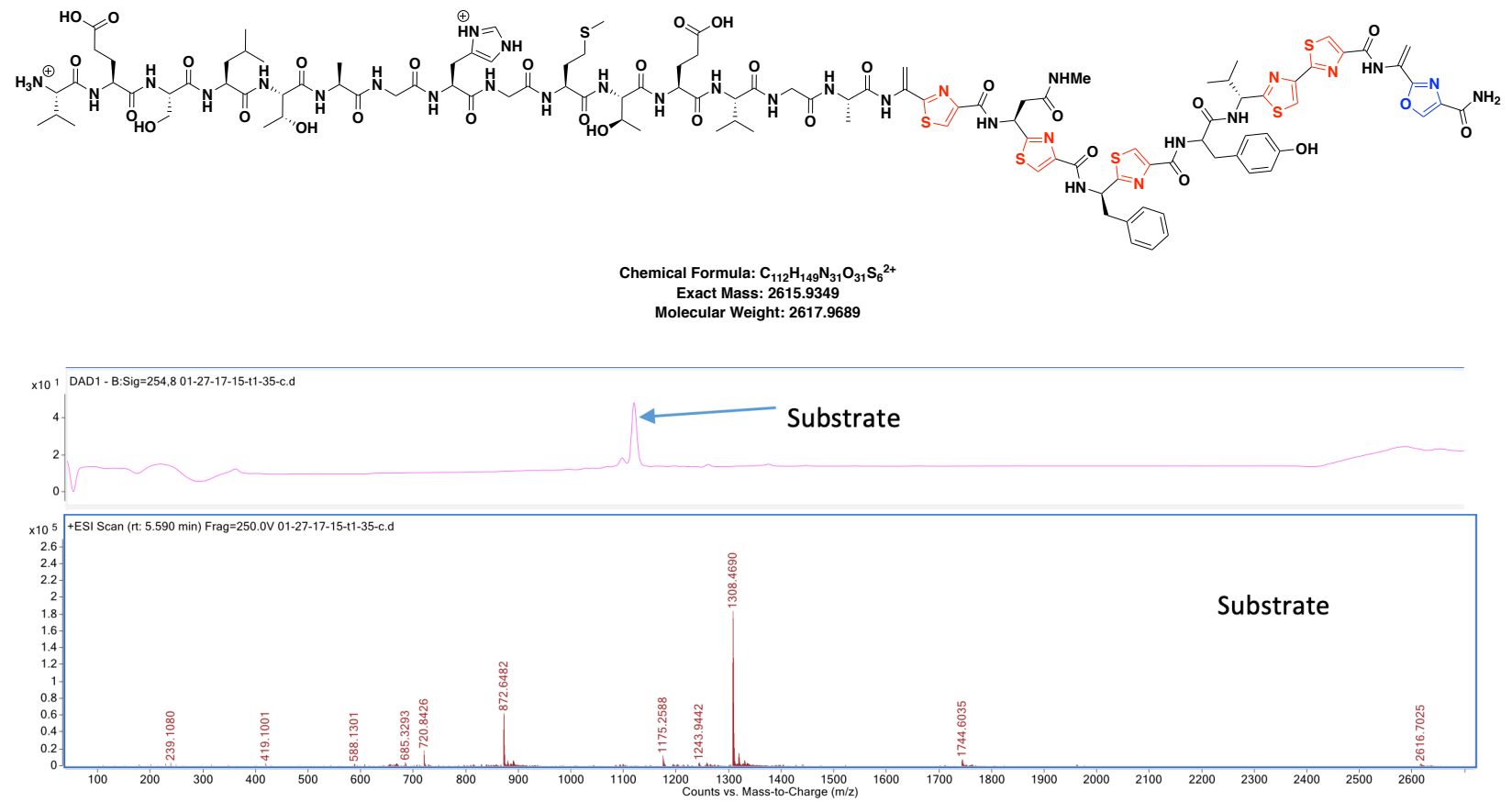

\section{Compound 4}



\section{Compound S26}
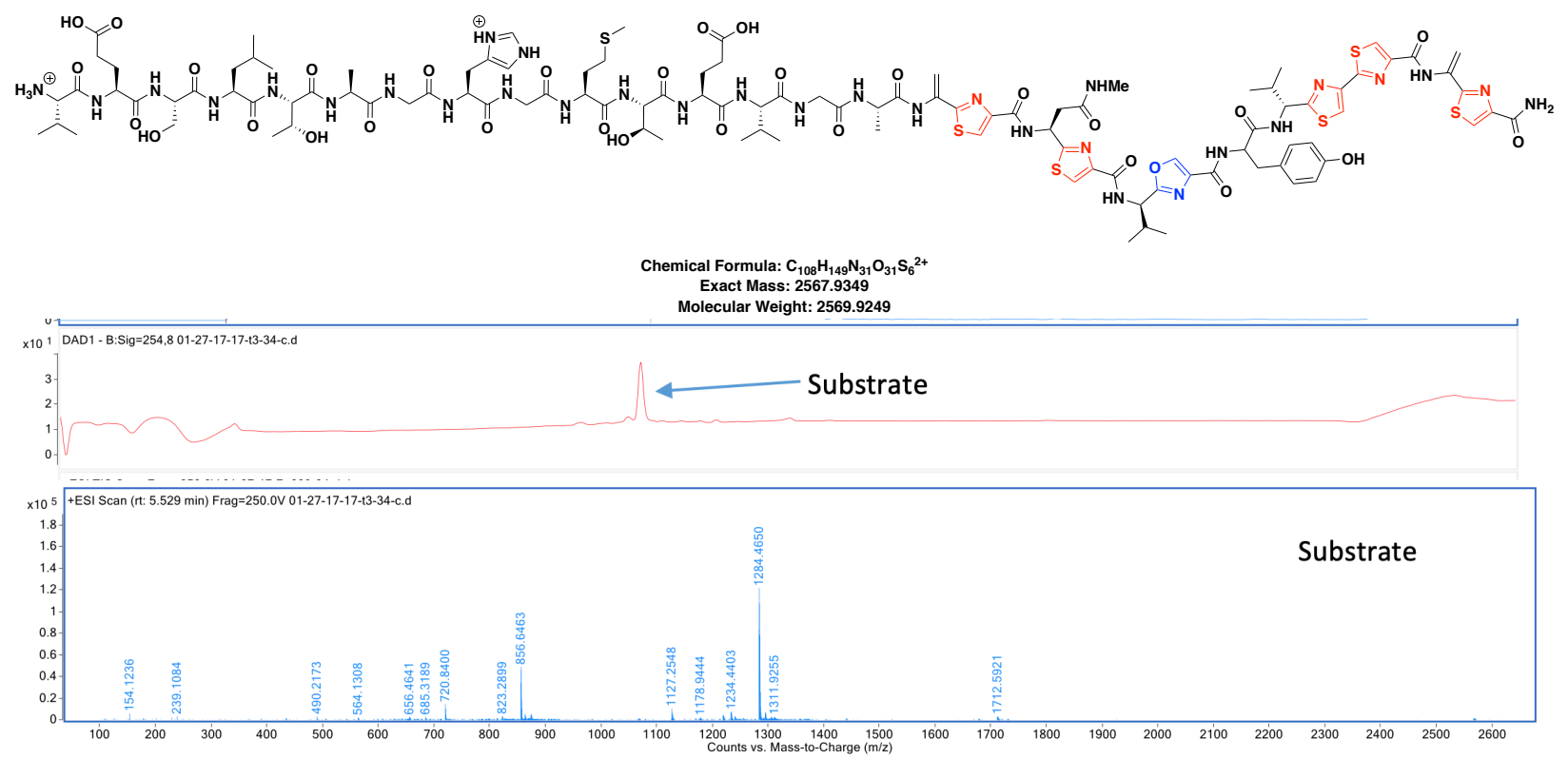

\section{Compound S27}



\section{Compound S28}

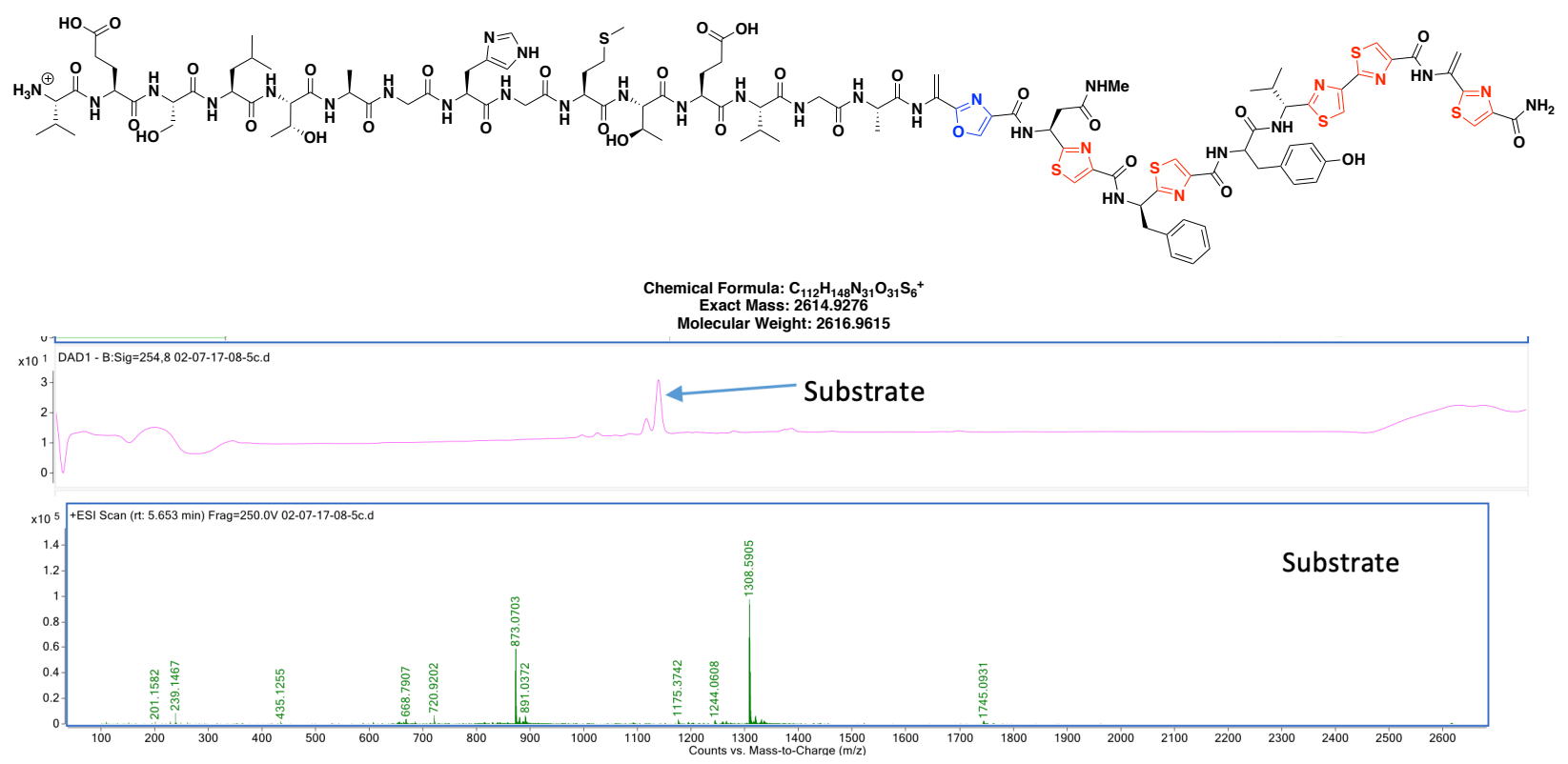

\section{Compound S29}
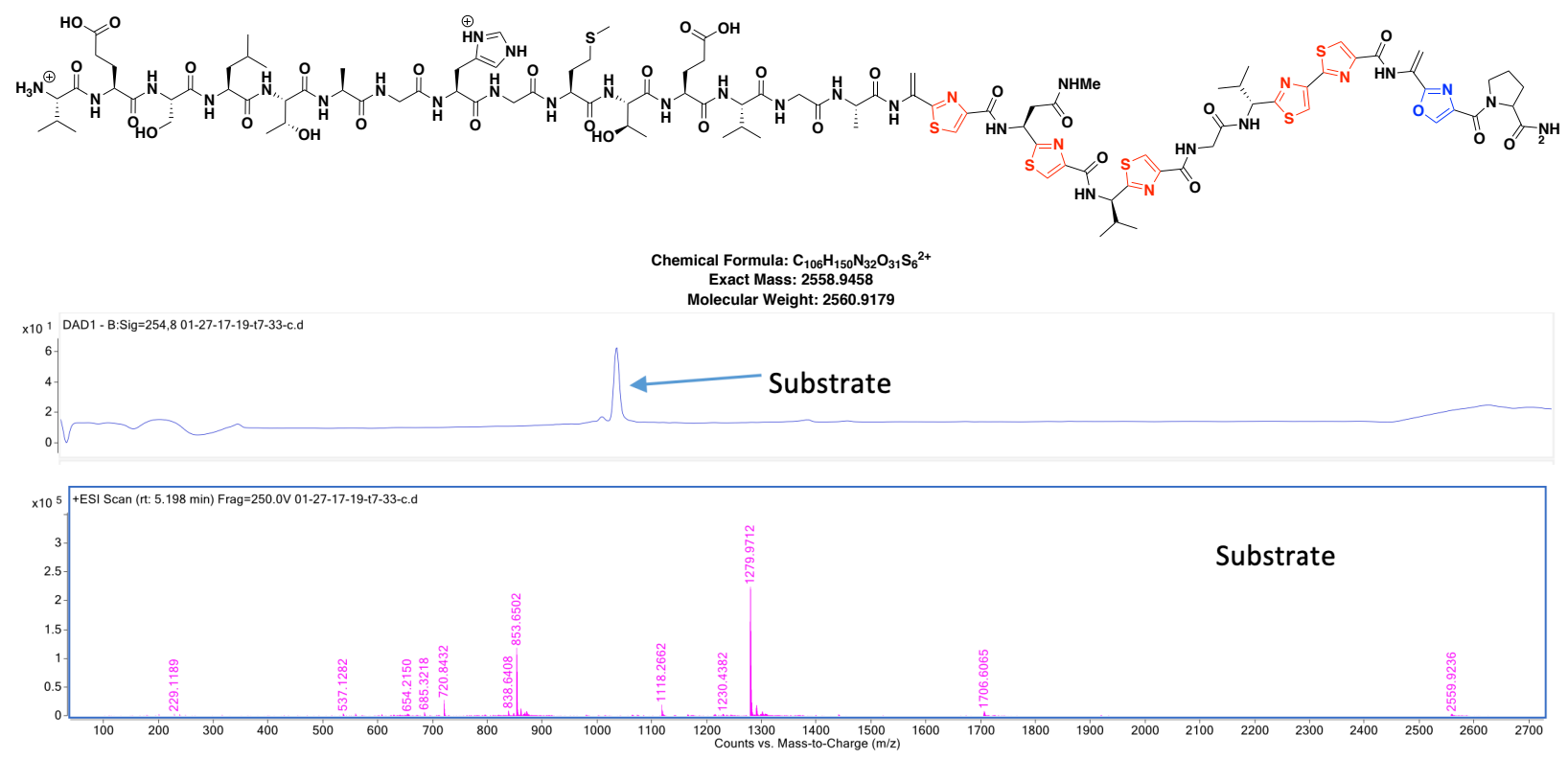


\section{Compound $\mathbf{S 3 0}$}

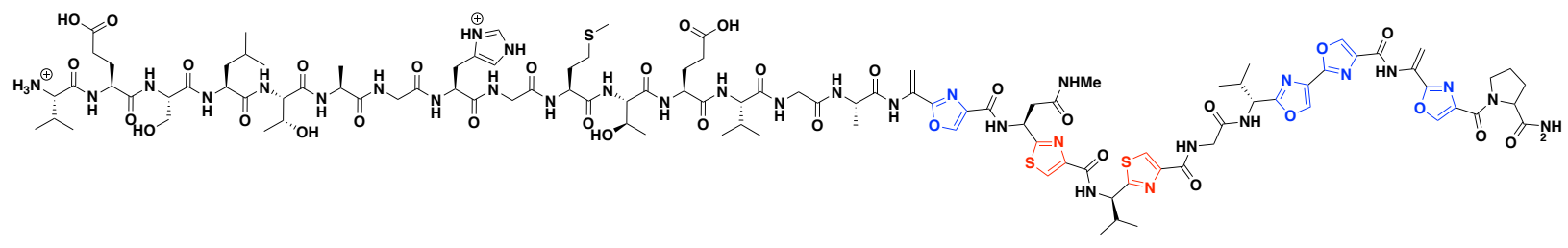

Chemical Formula: $\mathrm{C}_{106} \mathrm{H}_{150} \mathrm{~N}_{32} \mathrm{O}_{34} \mathrm{~S}_{3}{ }^{2+}$

Molecular Weight: 2512.7349



\section{Compound S31}

(n)

Chemical Formula: $\mathrm{C}_{106} \mathrm{H}_{146} \mathrm{~N}_{30} \mathrm{O}_{36} \mathrm{~S}^{2+}$
Exact Mass: 2447.0226

Molecular Weight: 2448.5669
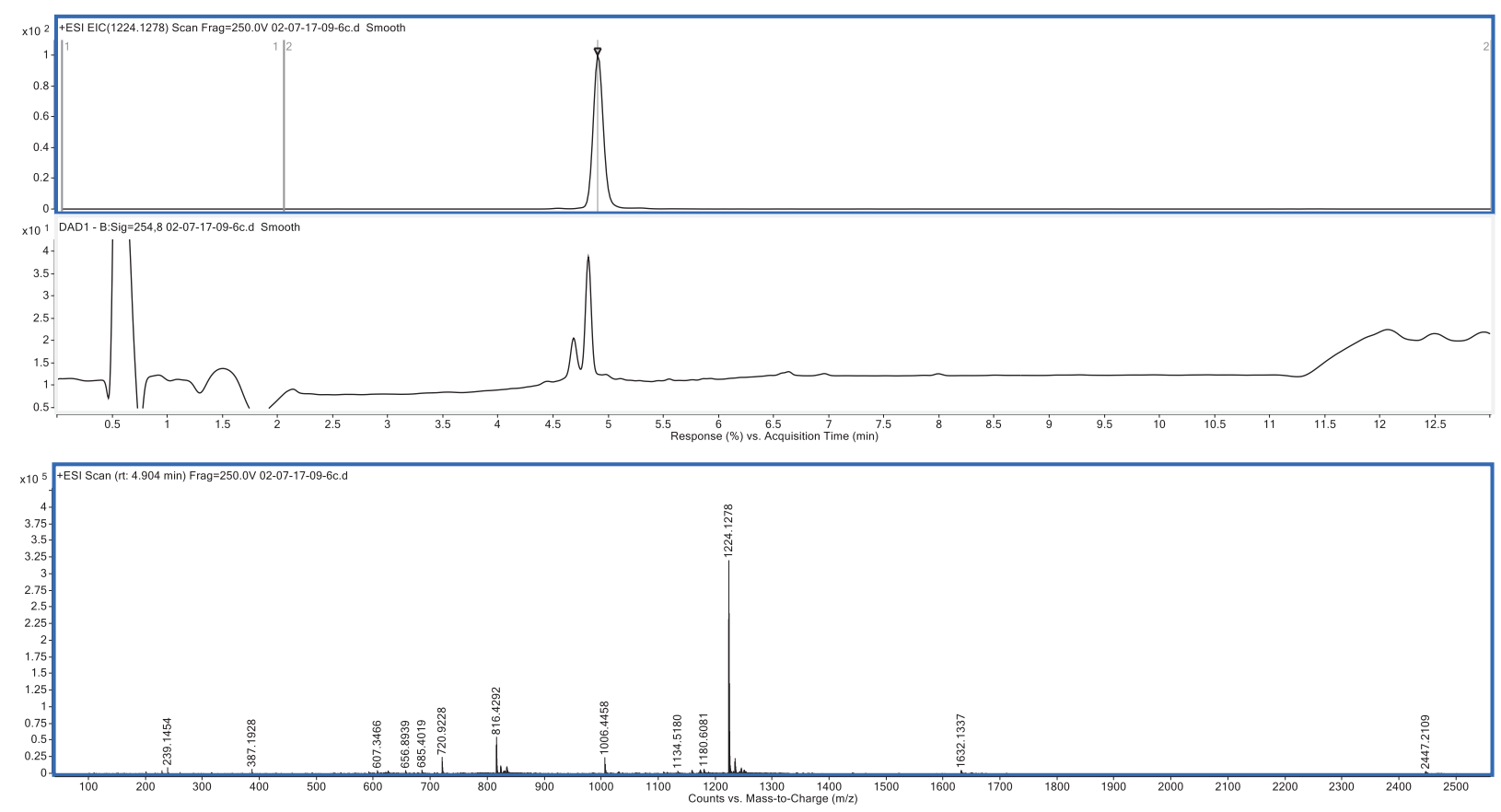


\section{Compound 4'}
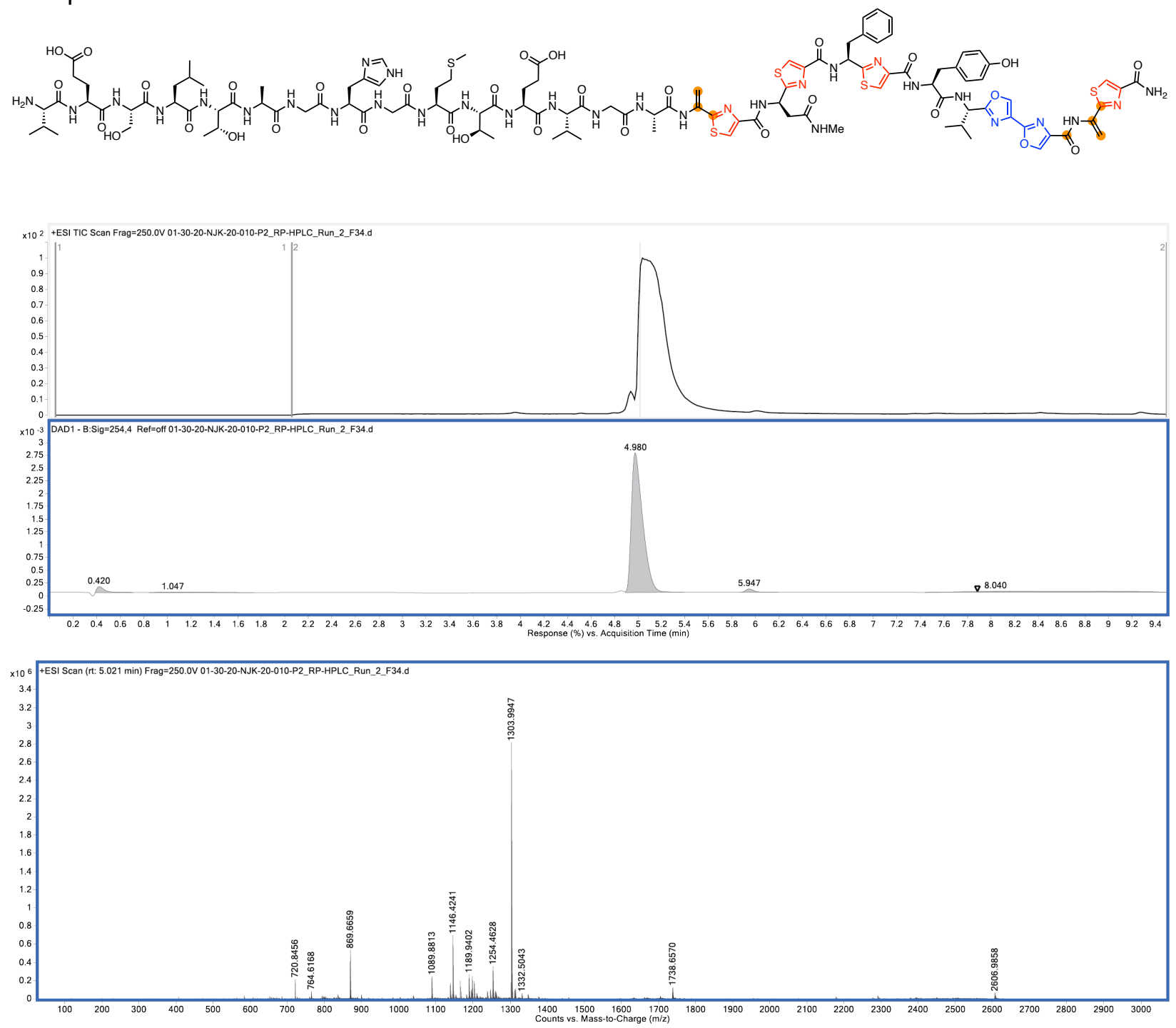


\section{NMR Spectra}
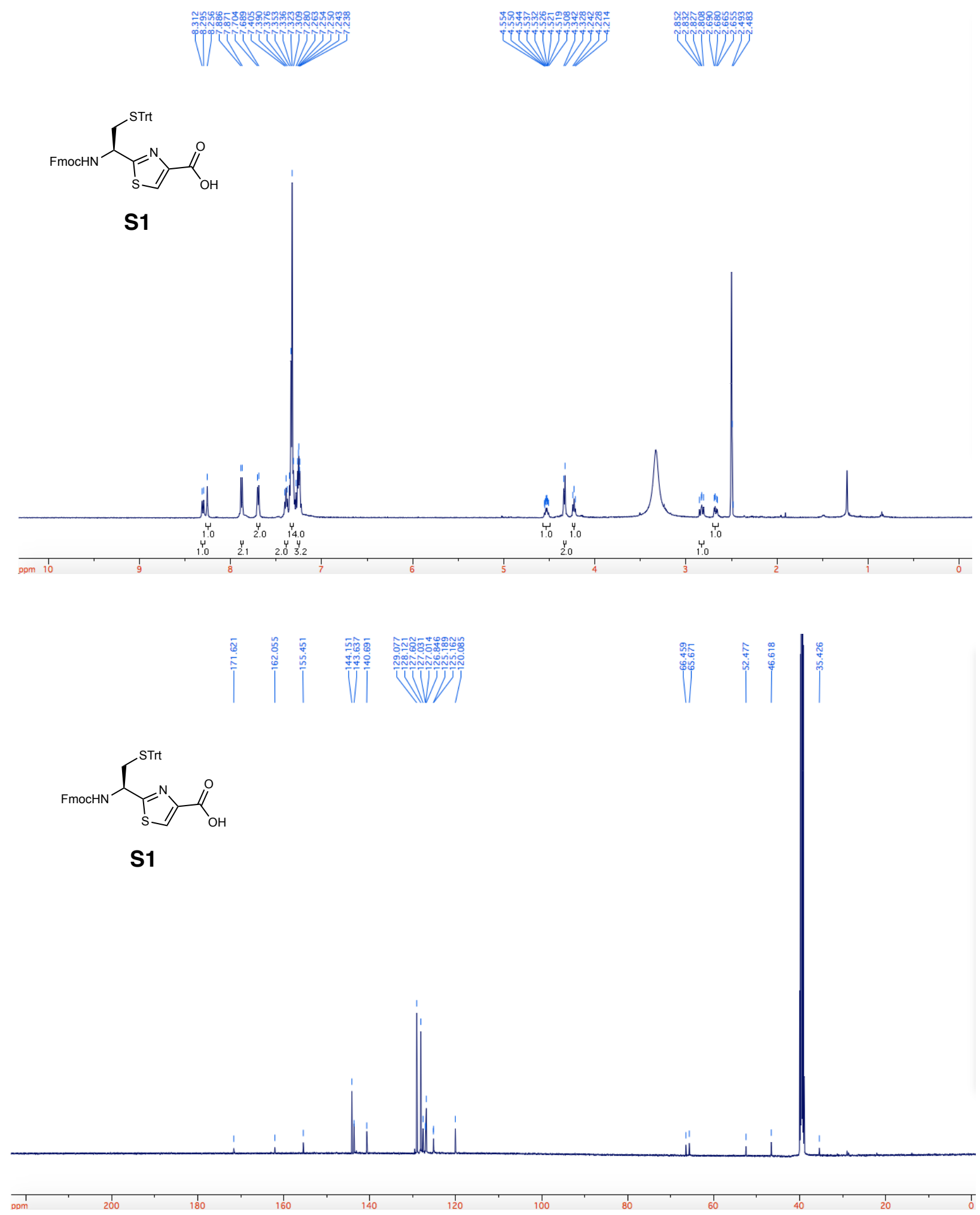


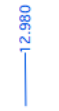

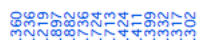

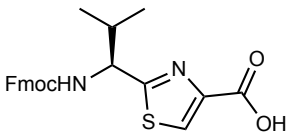

S2


S2






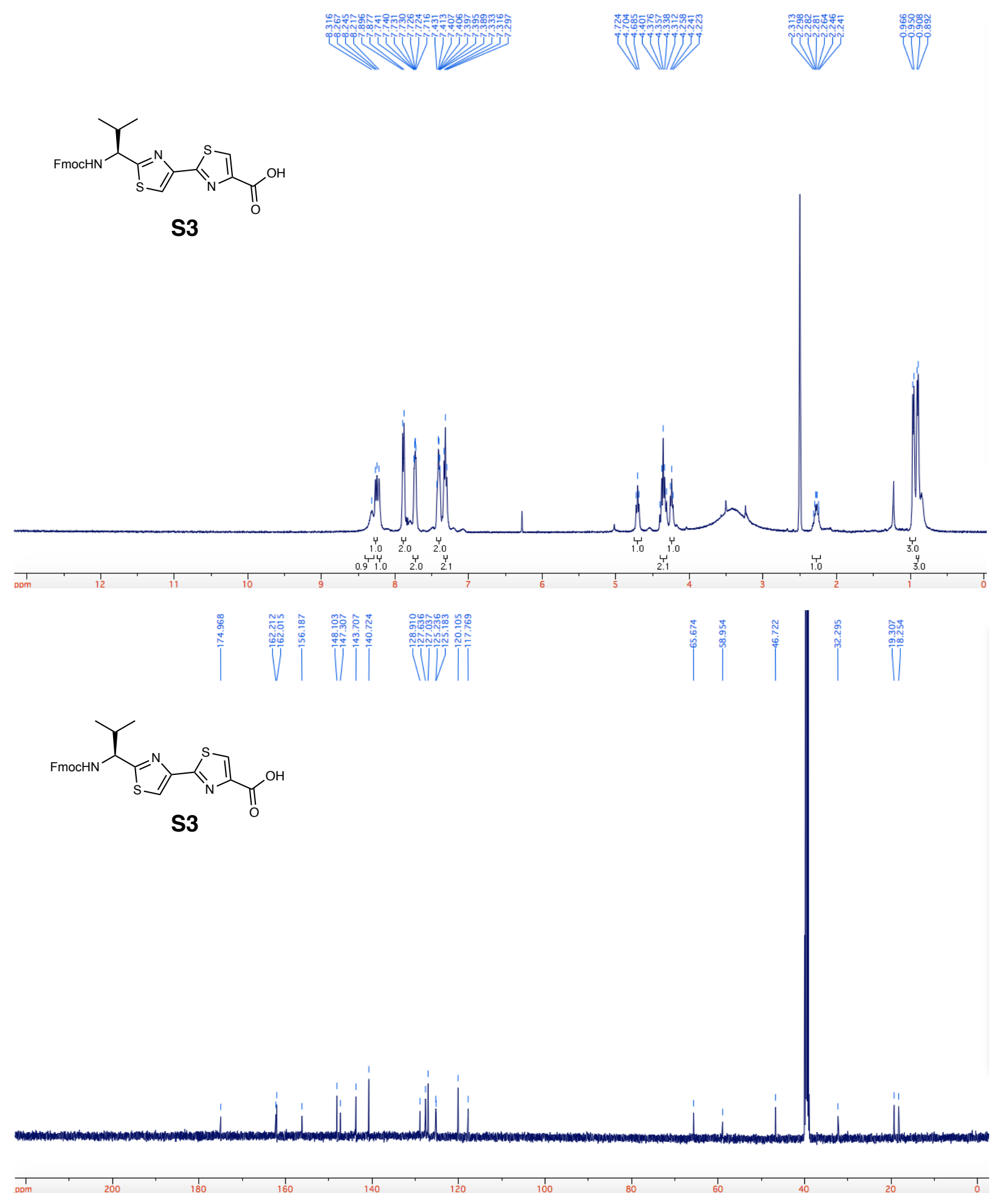



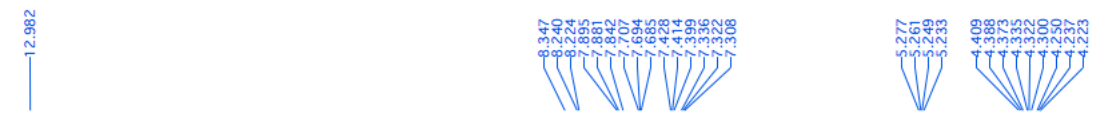

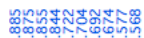

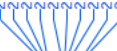

SmochN

S4

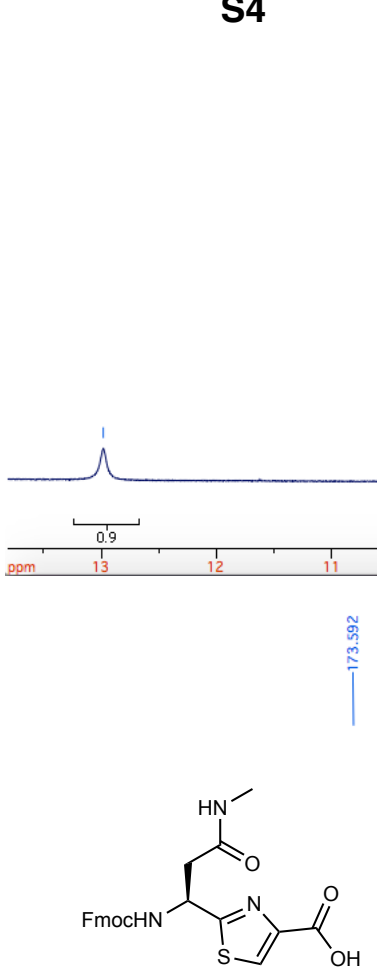

S4

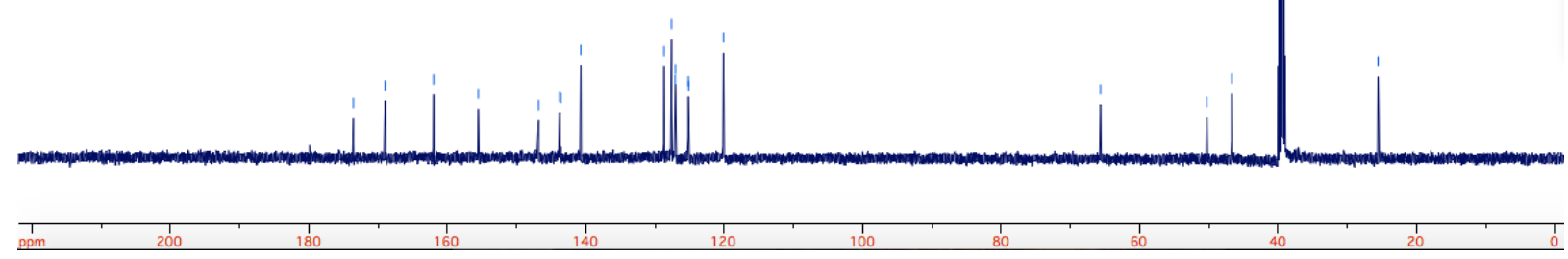










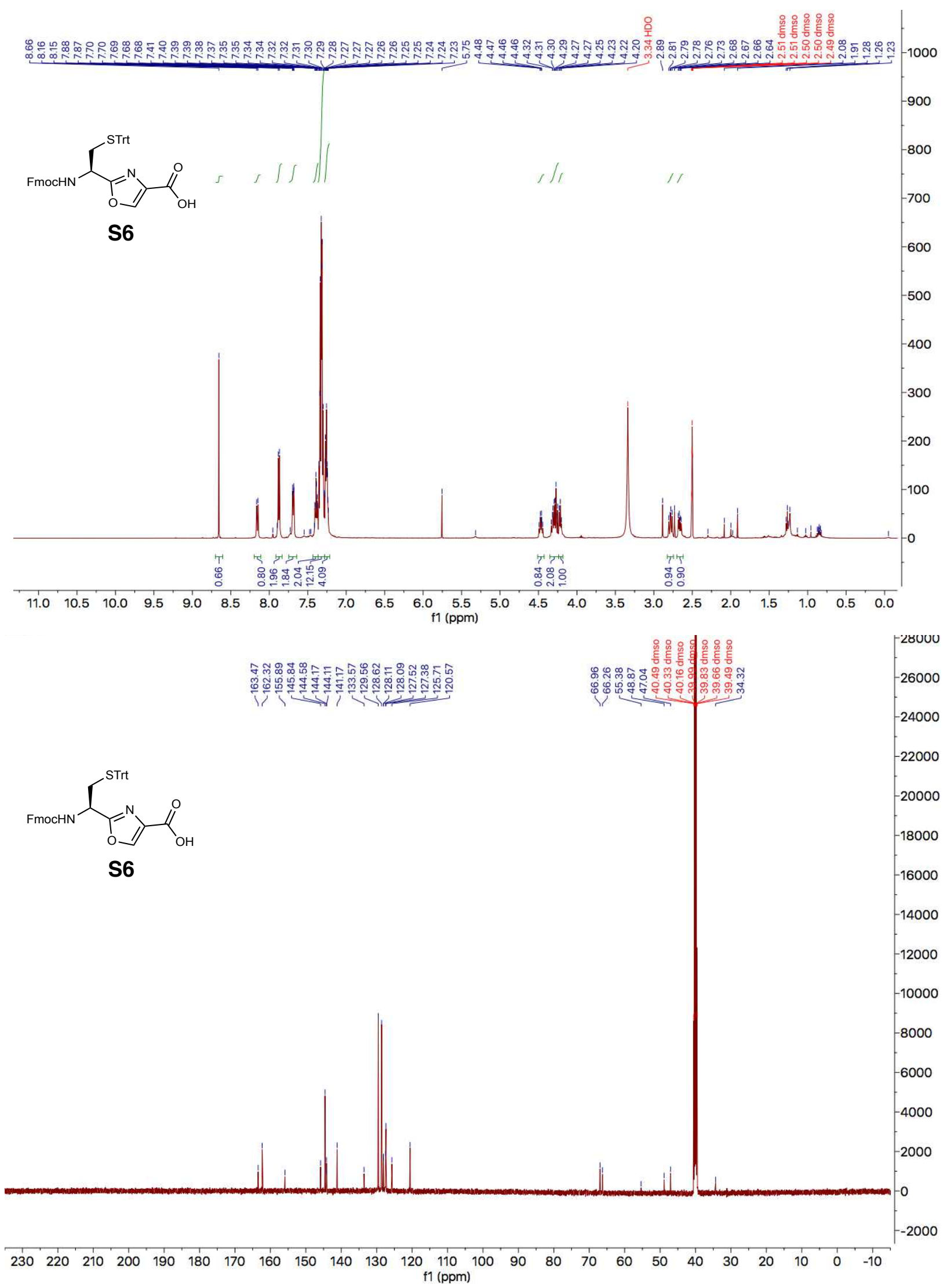




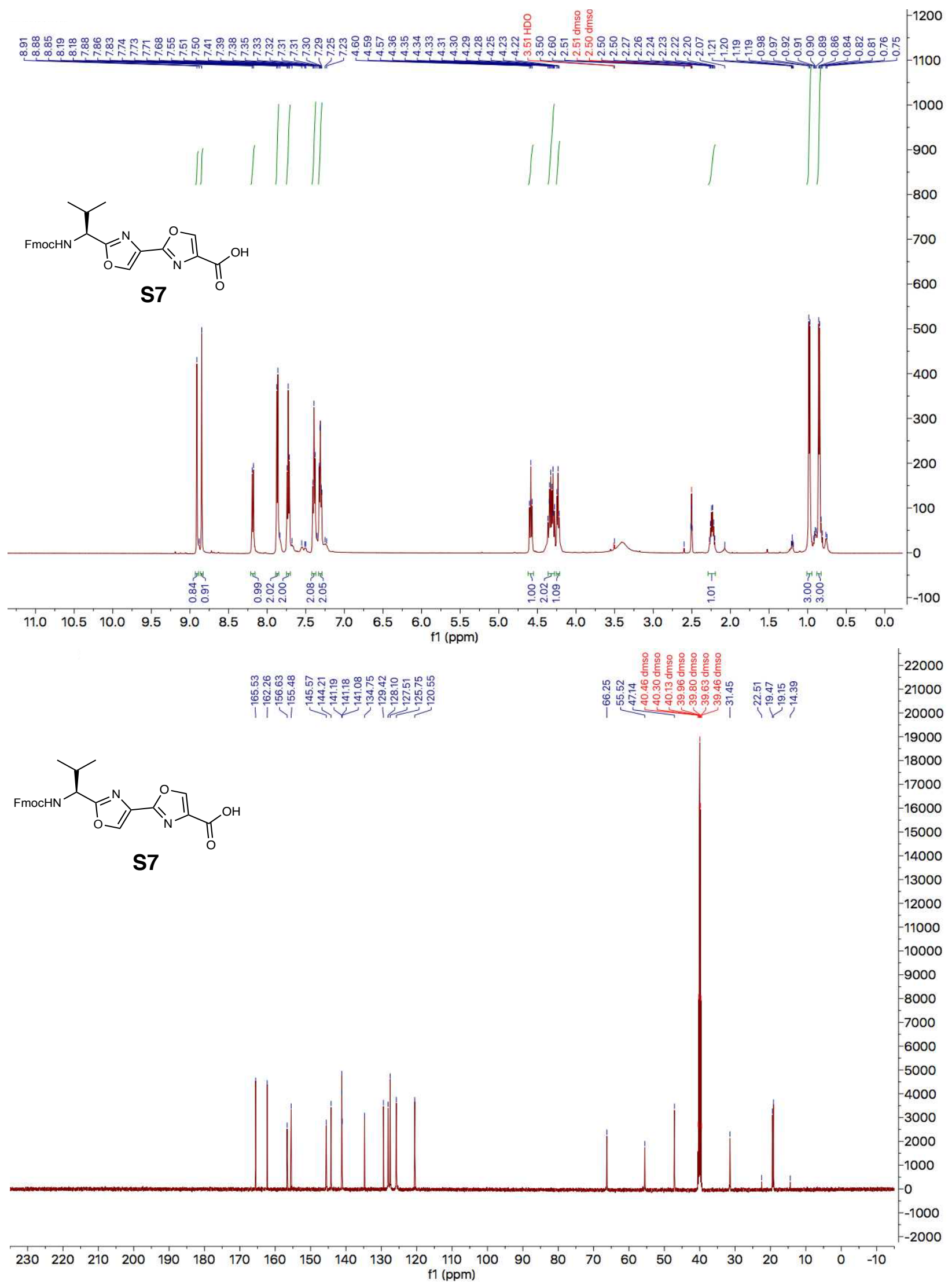




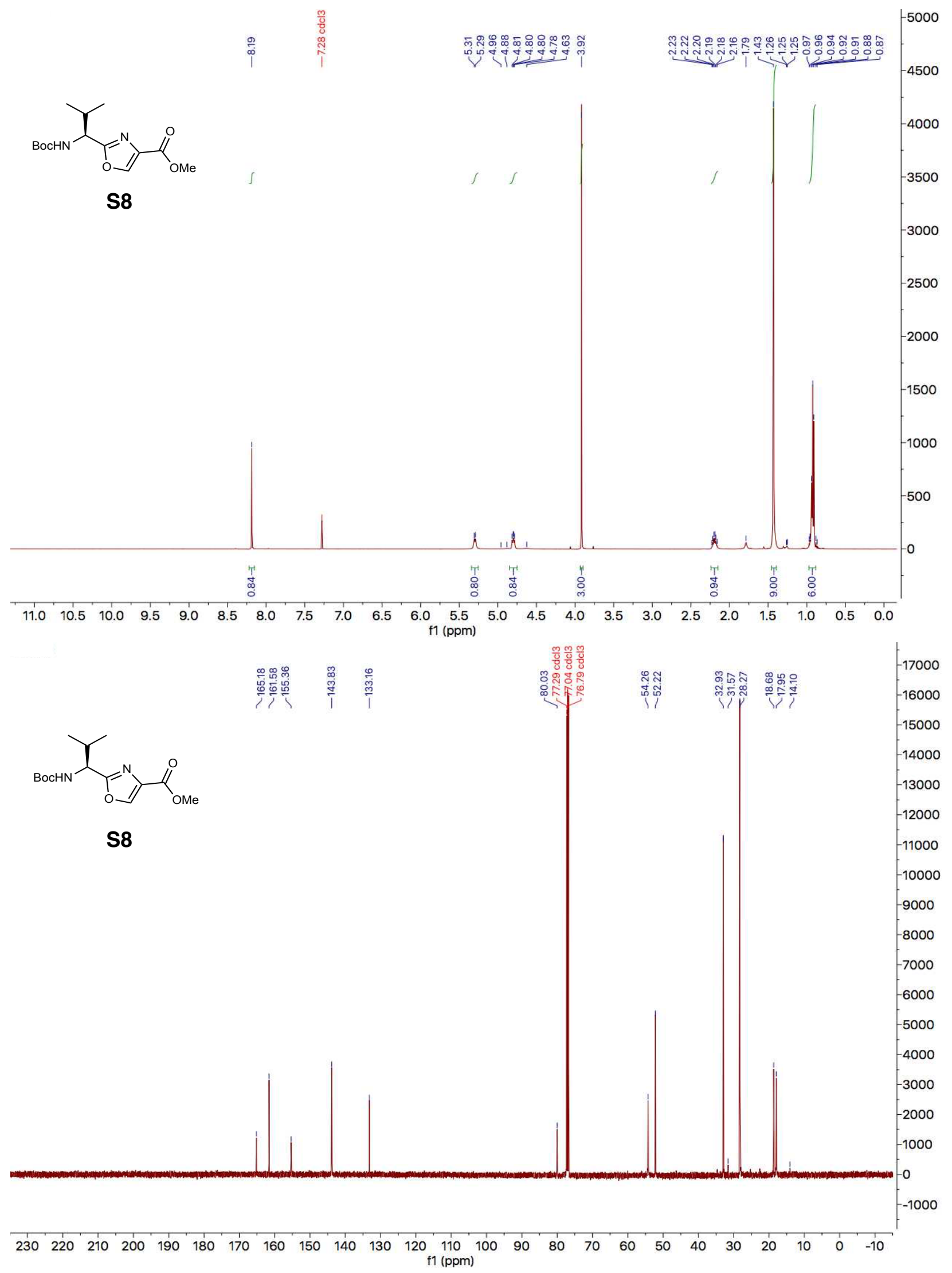




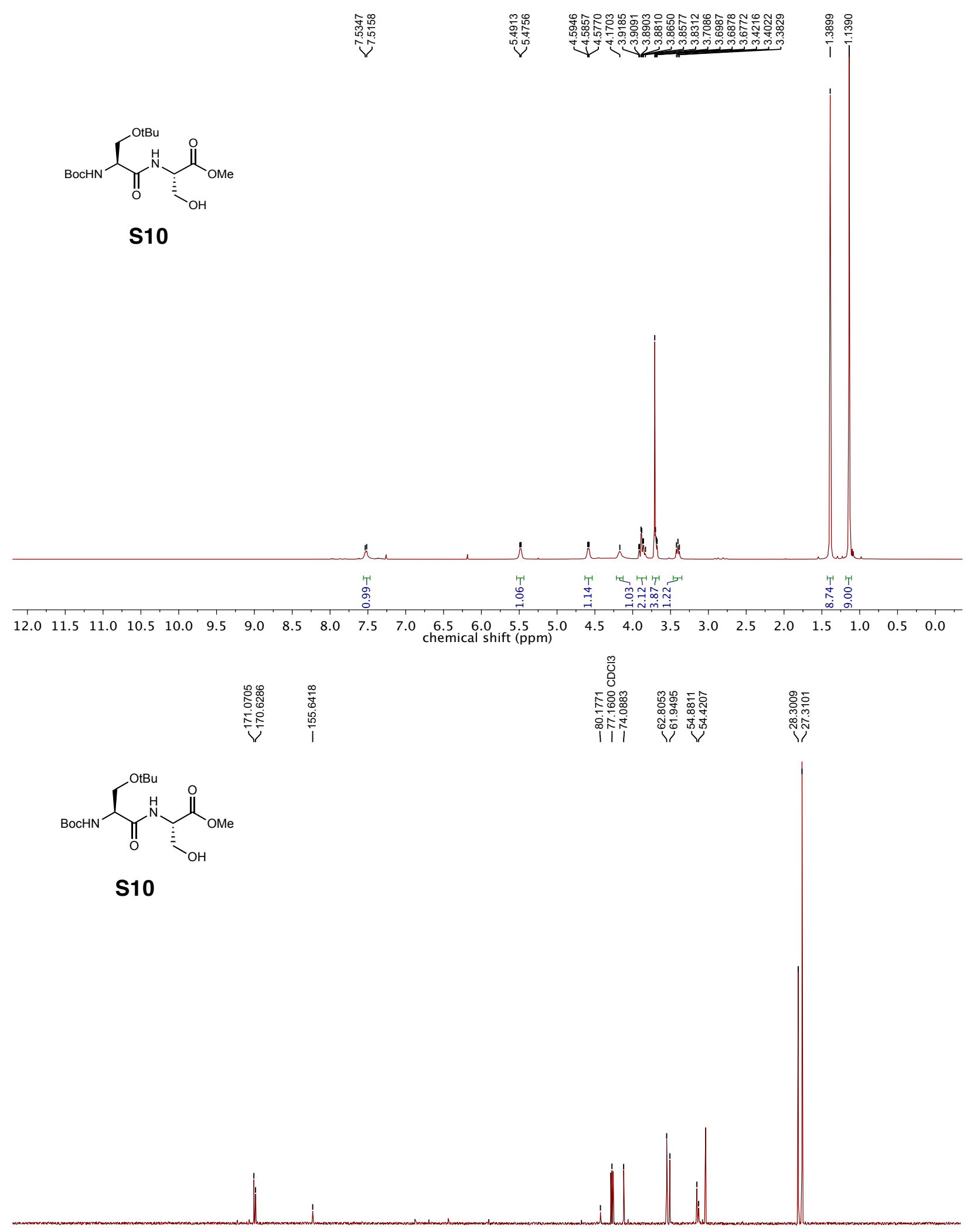

$\begin{array}{lllllllllllllllllllllllll}230 & 220 & 210 & 200 & 190 & 180 & 170 & 160 & 150 & 140 & 130 & 120 & 110 & 100 & 90 & 80 & 70 & 60 & 50 & 40 & 30 & 20 & 10 & 0 & -10\end{array}$ 


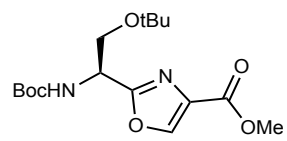

\section{S11}

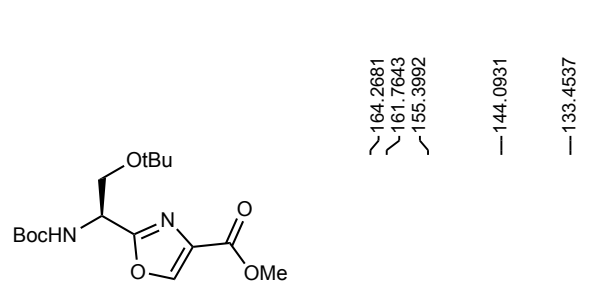

Mu

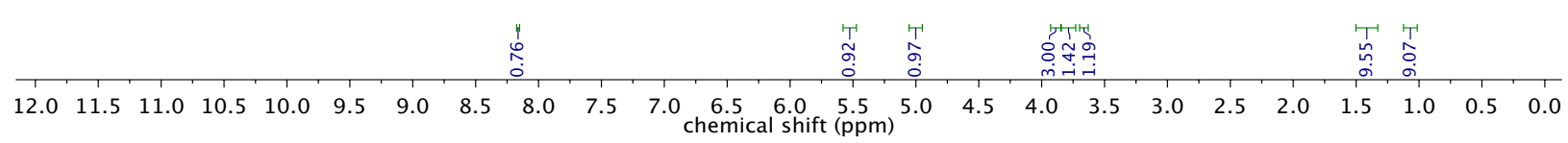

S11



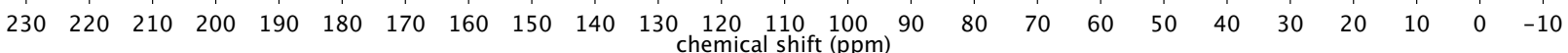




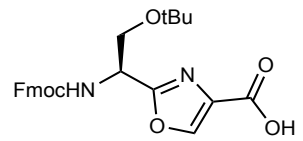

S9


S9

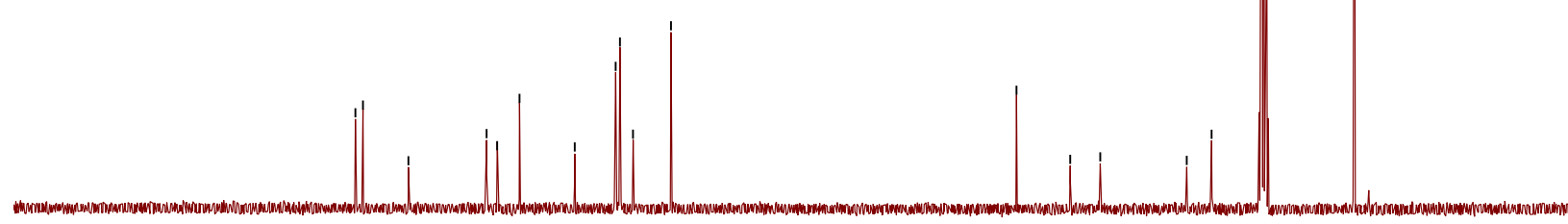

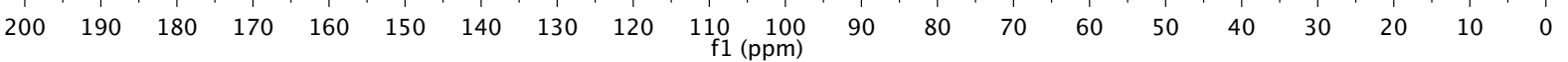




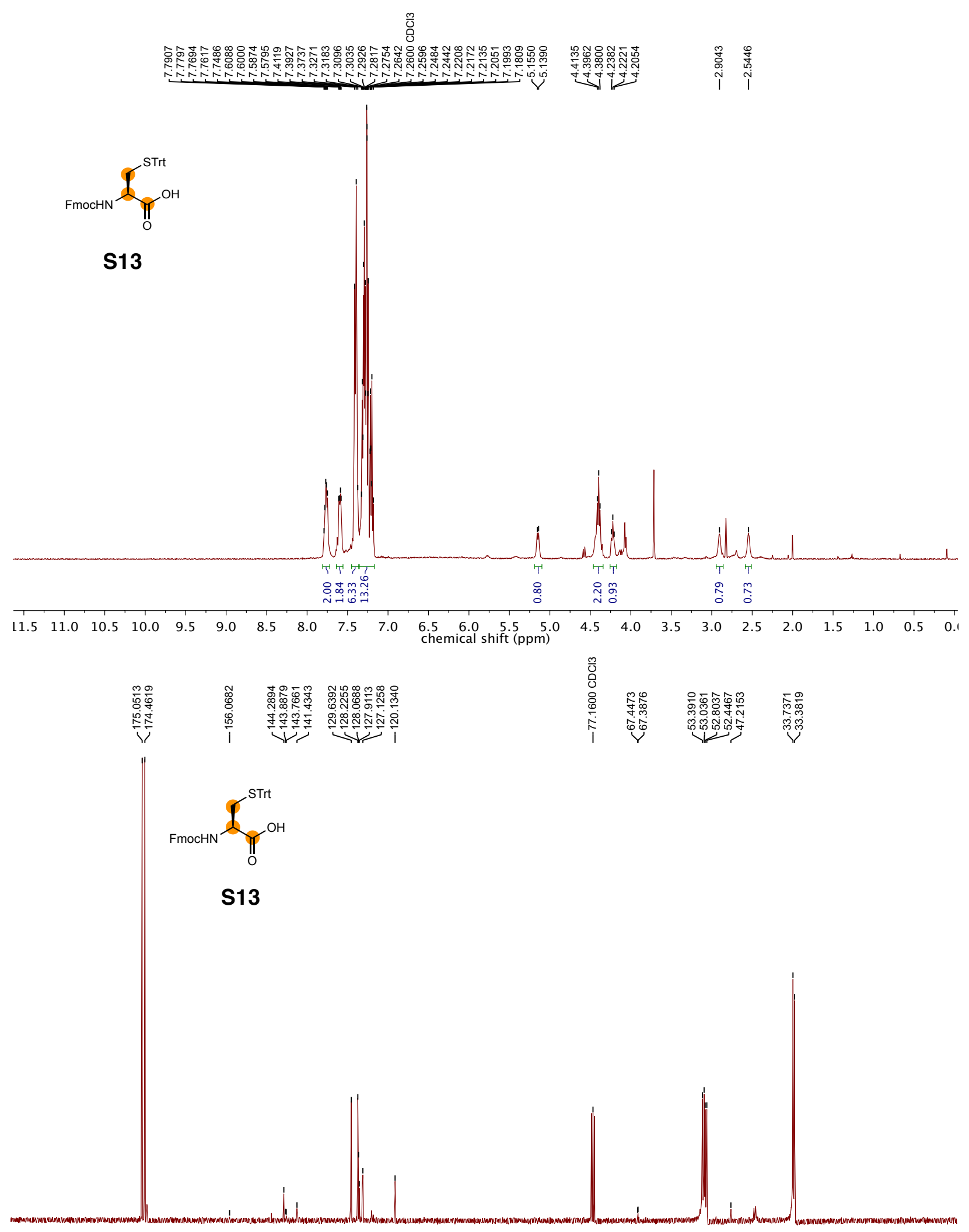

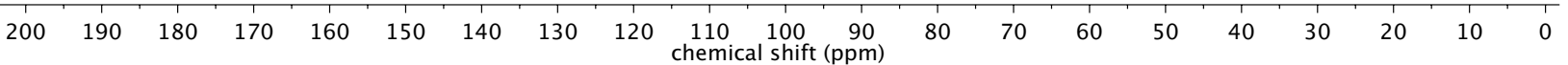



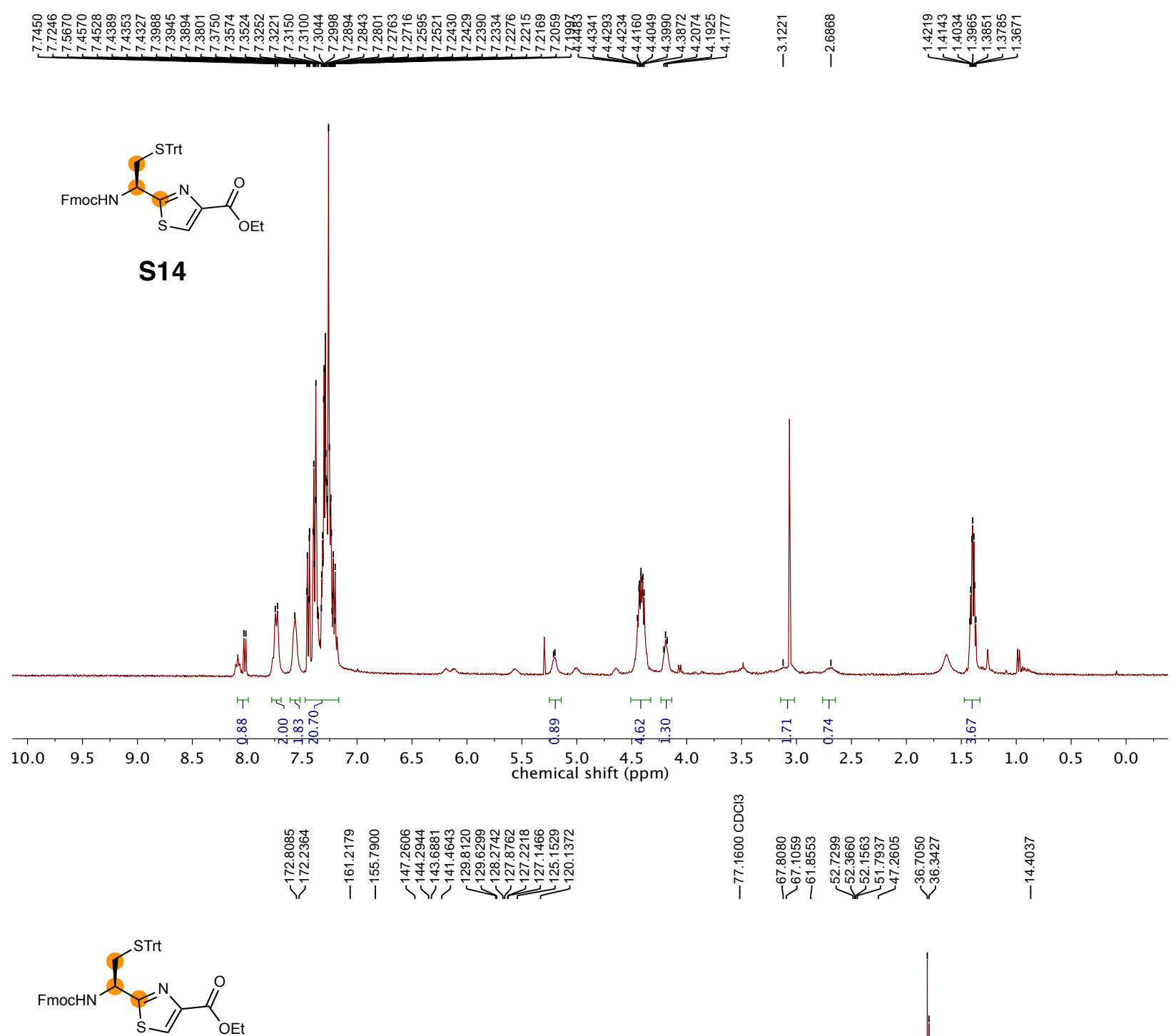

S14

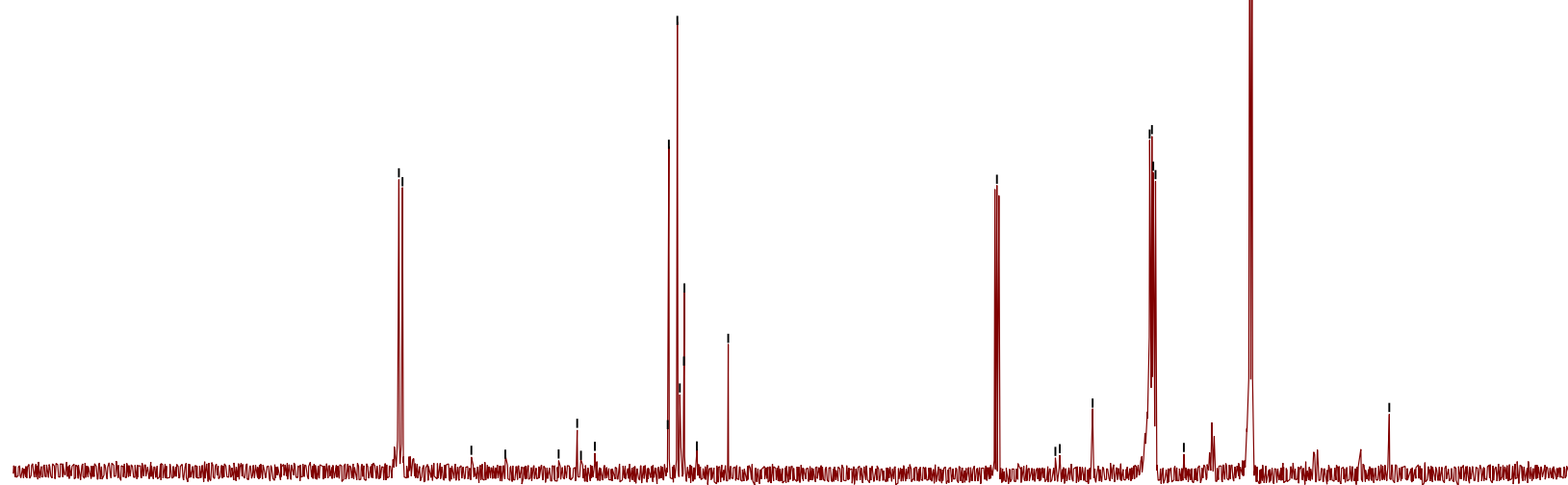

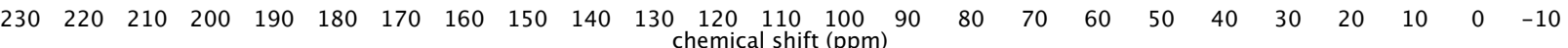




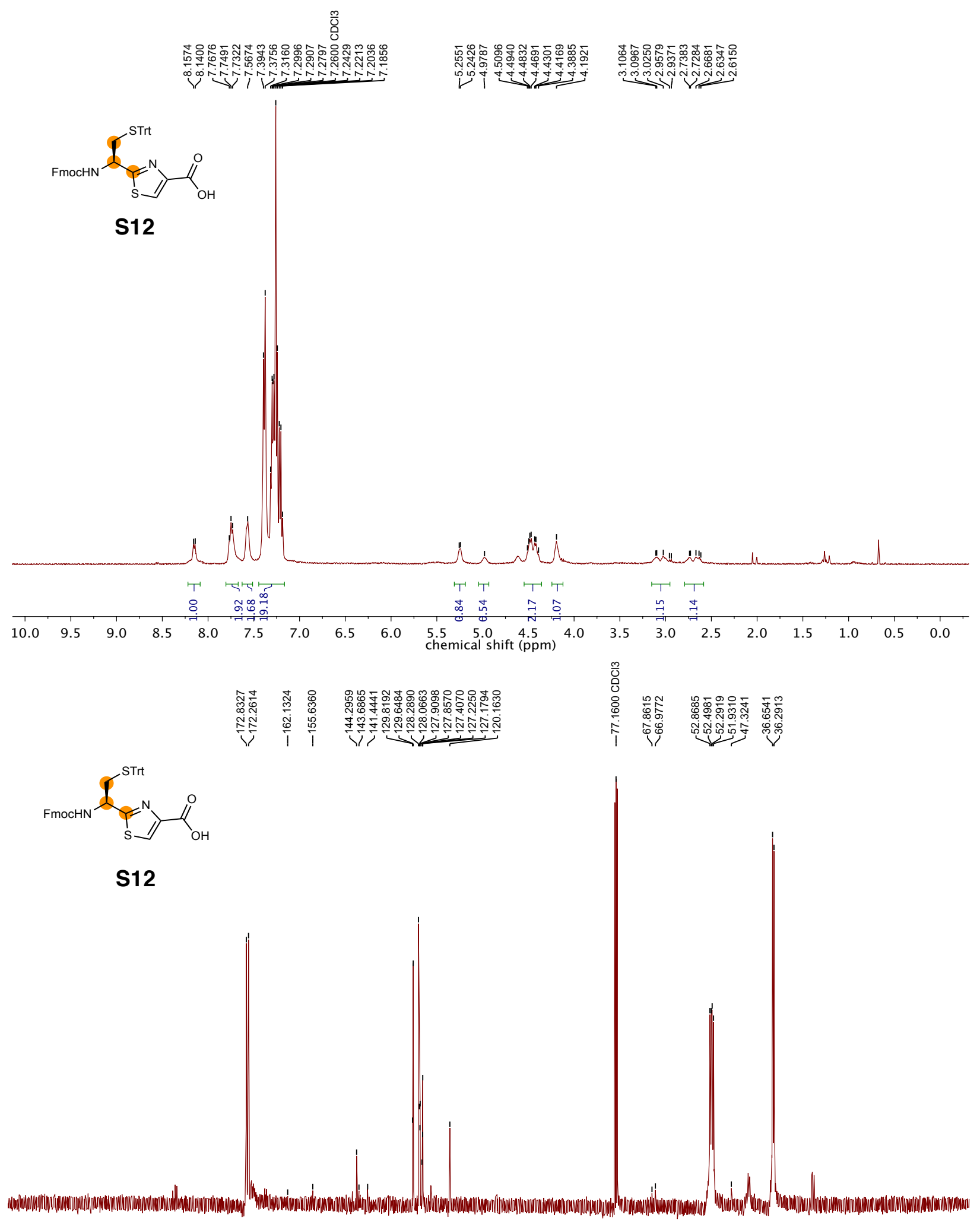

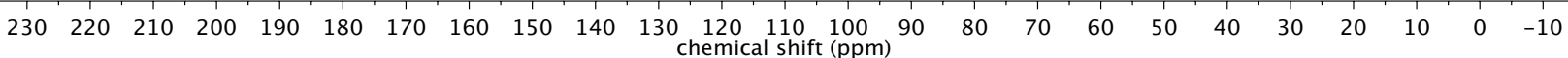









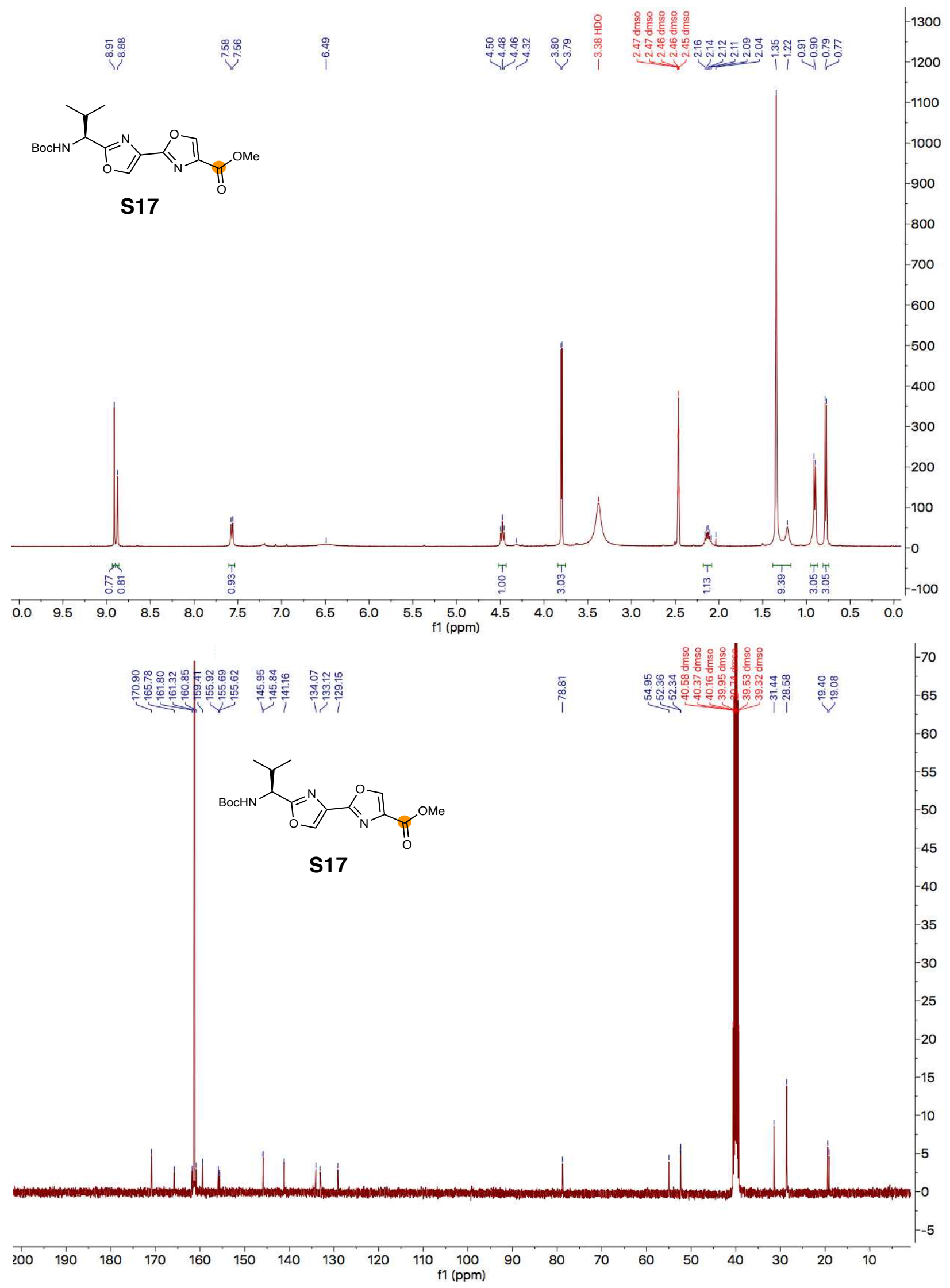




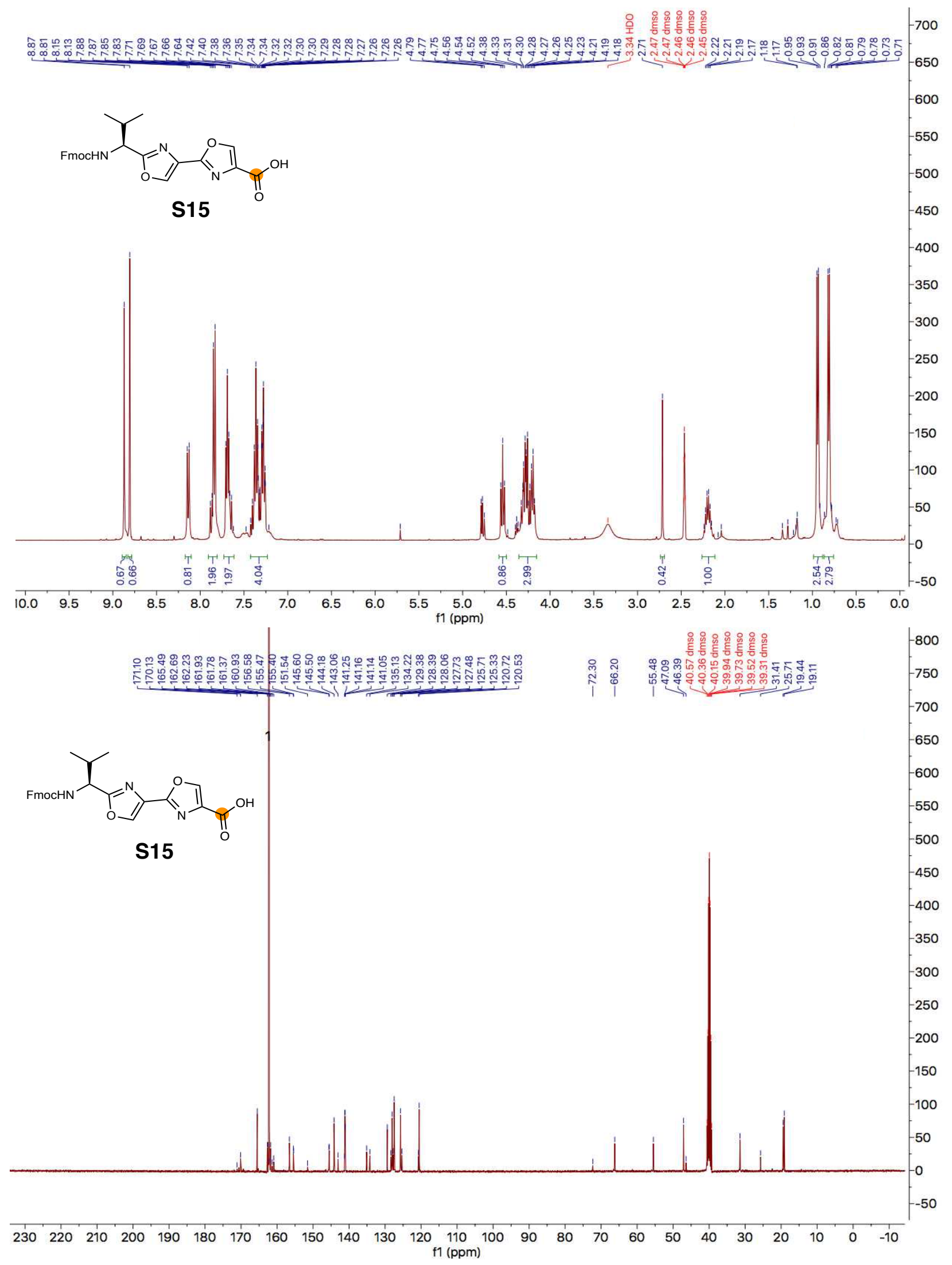




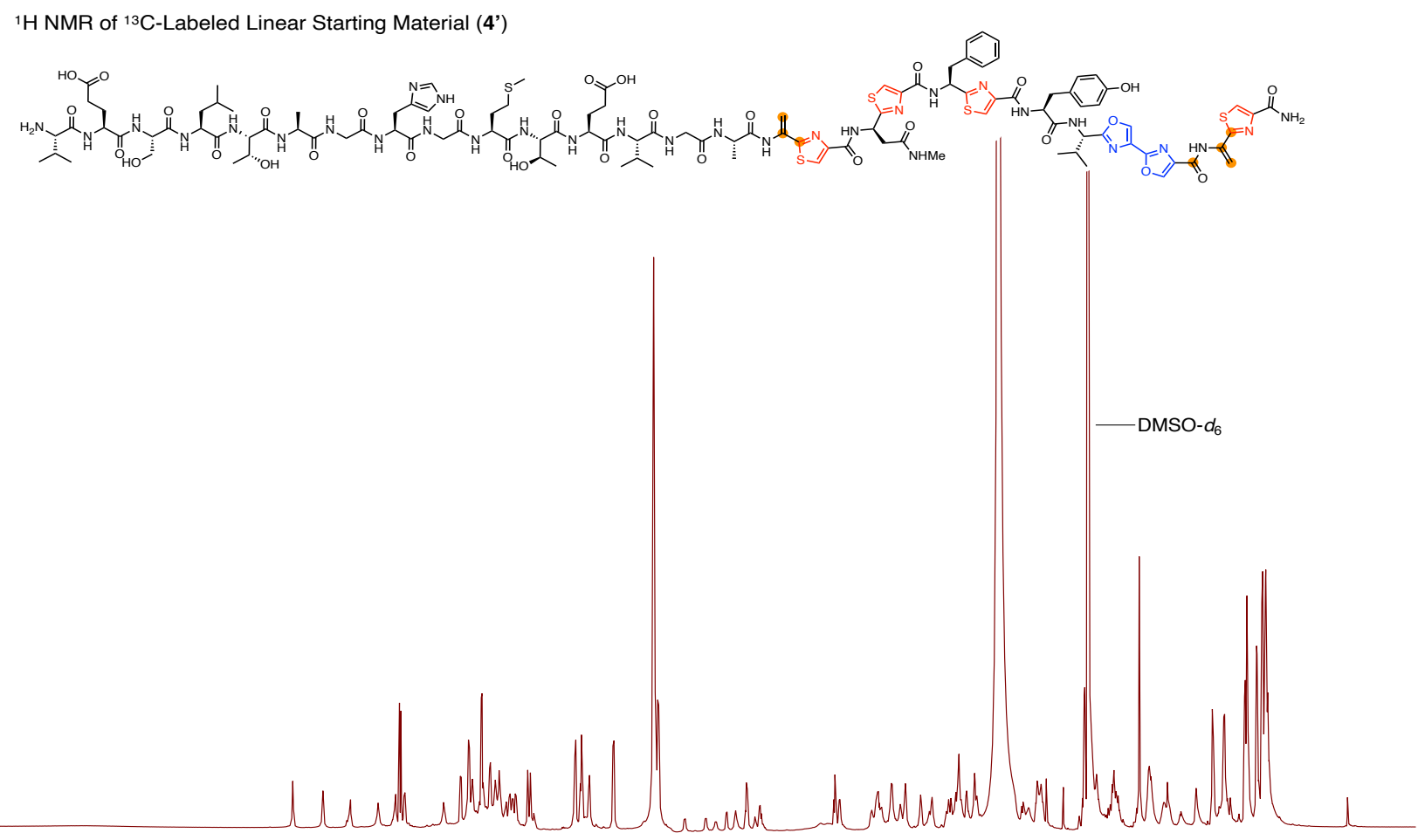

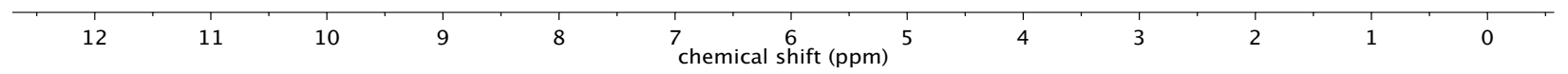

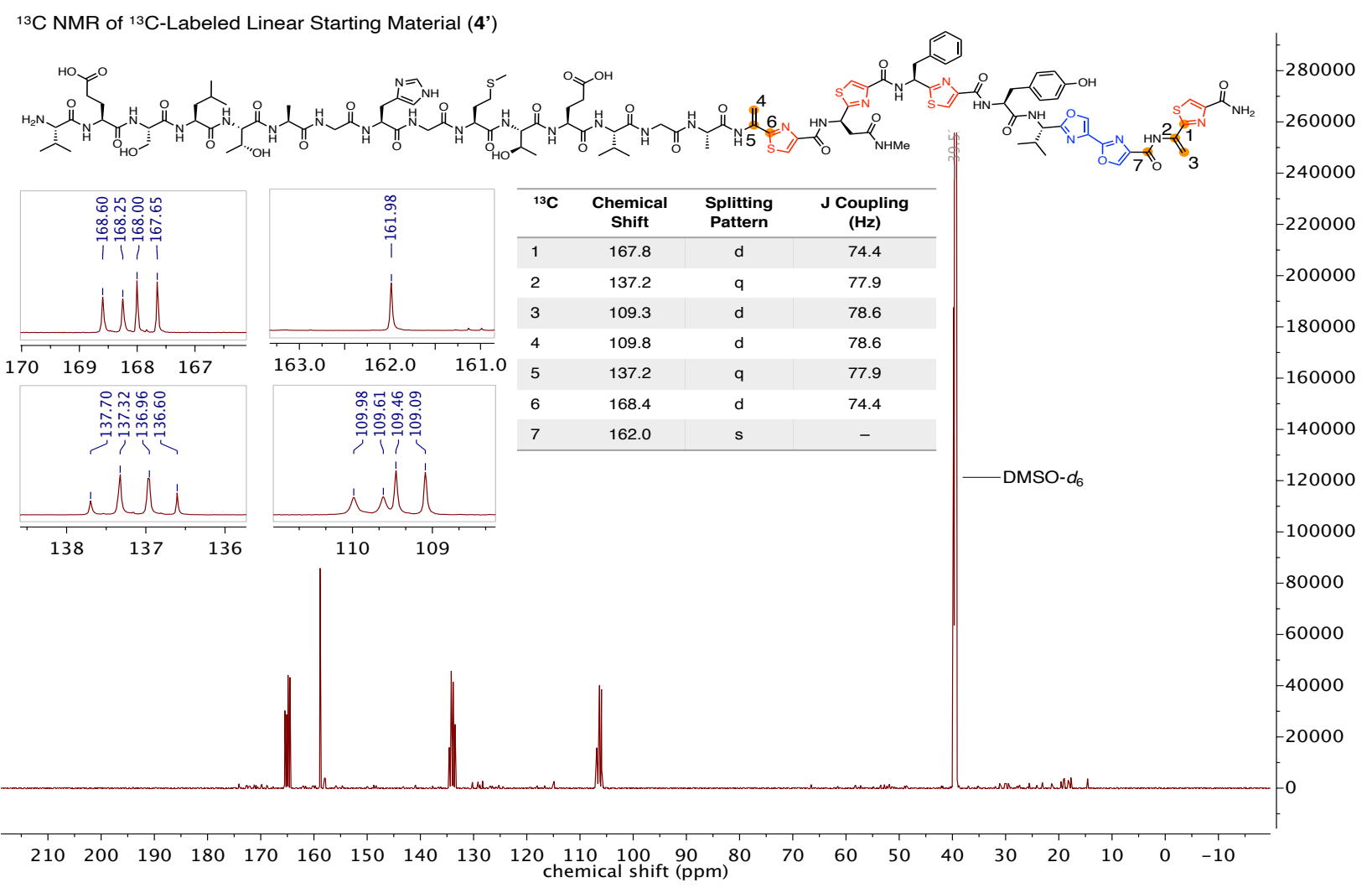


${ }^{1} \mathrm{H}$ NMR of ${ }^{13} \mathrm{C}$-Labeled Diketone Intermediate (6')

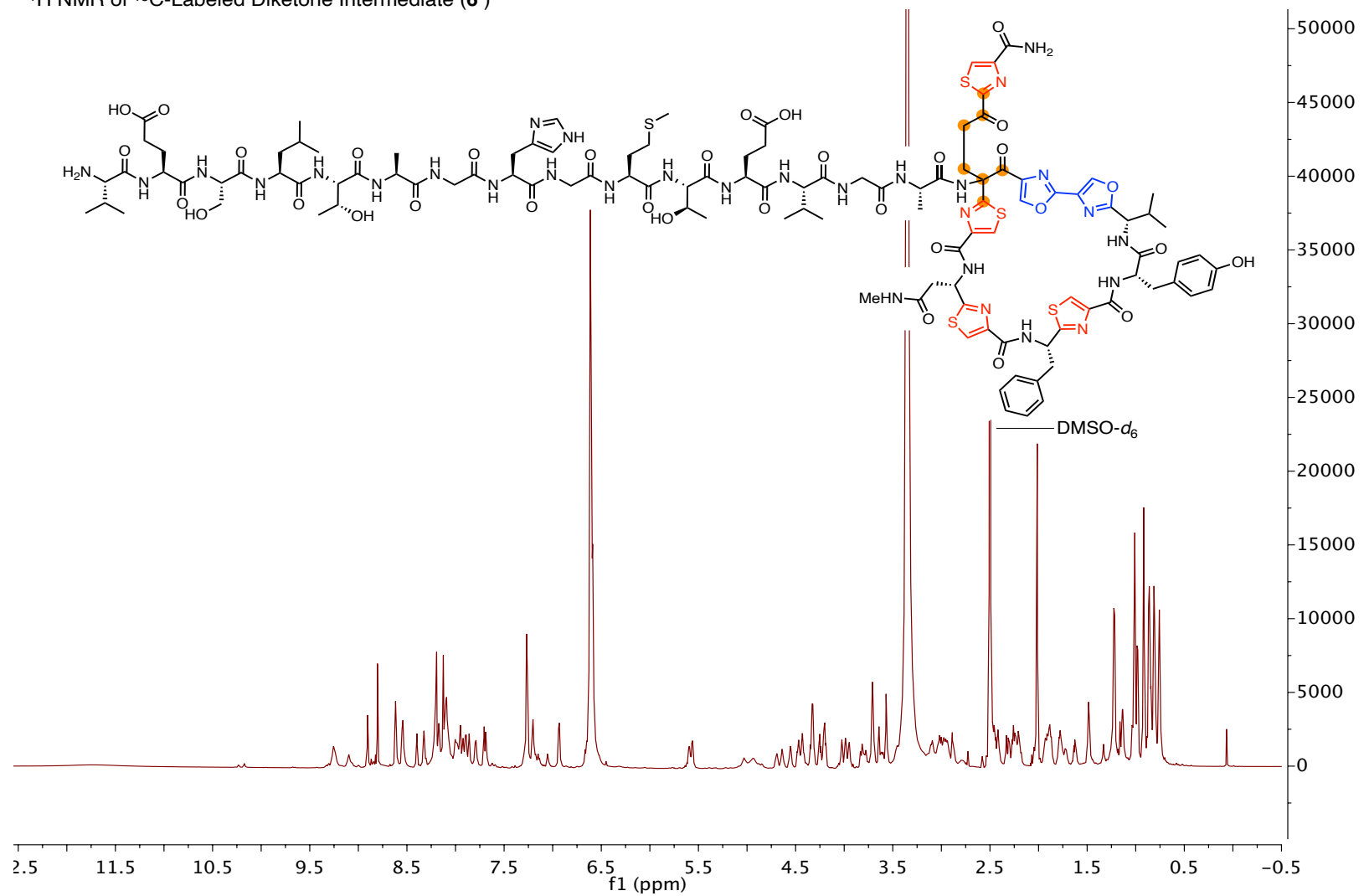

${ }^{13} \mathrm{C}$ NMR of ${ }^{13} \mathrm{C}$-Labeled Diketone Intermediate (6')





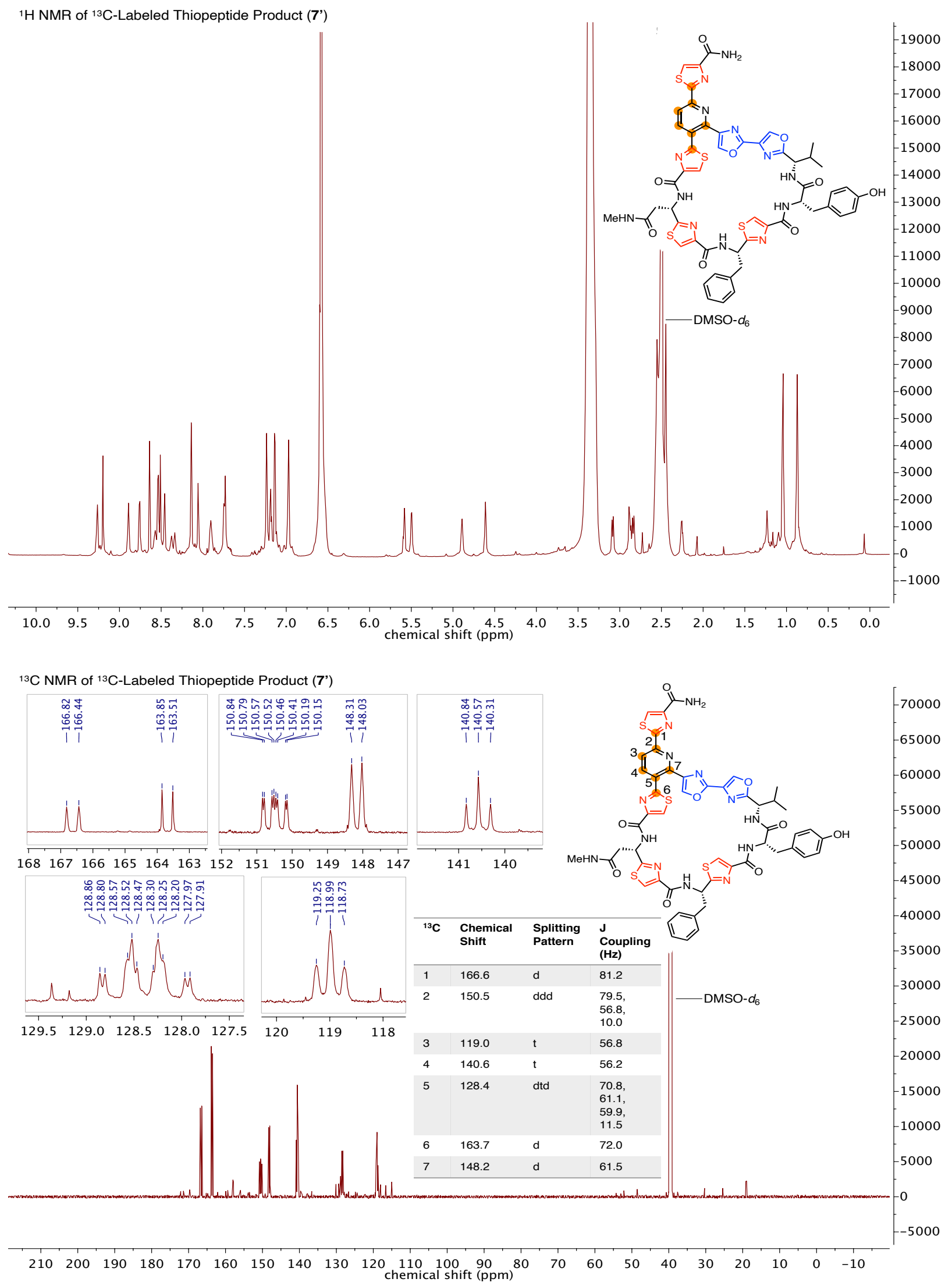
${ }^{13} \mathrm{C}-{ }^{13} \mathrm{C}$ COSY of ${ }^{13} \mathrm{C}$-labeled Diketone Intermediate (6')

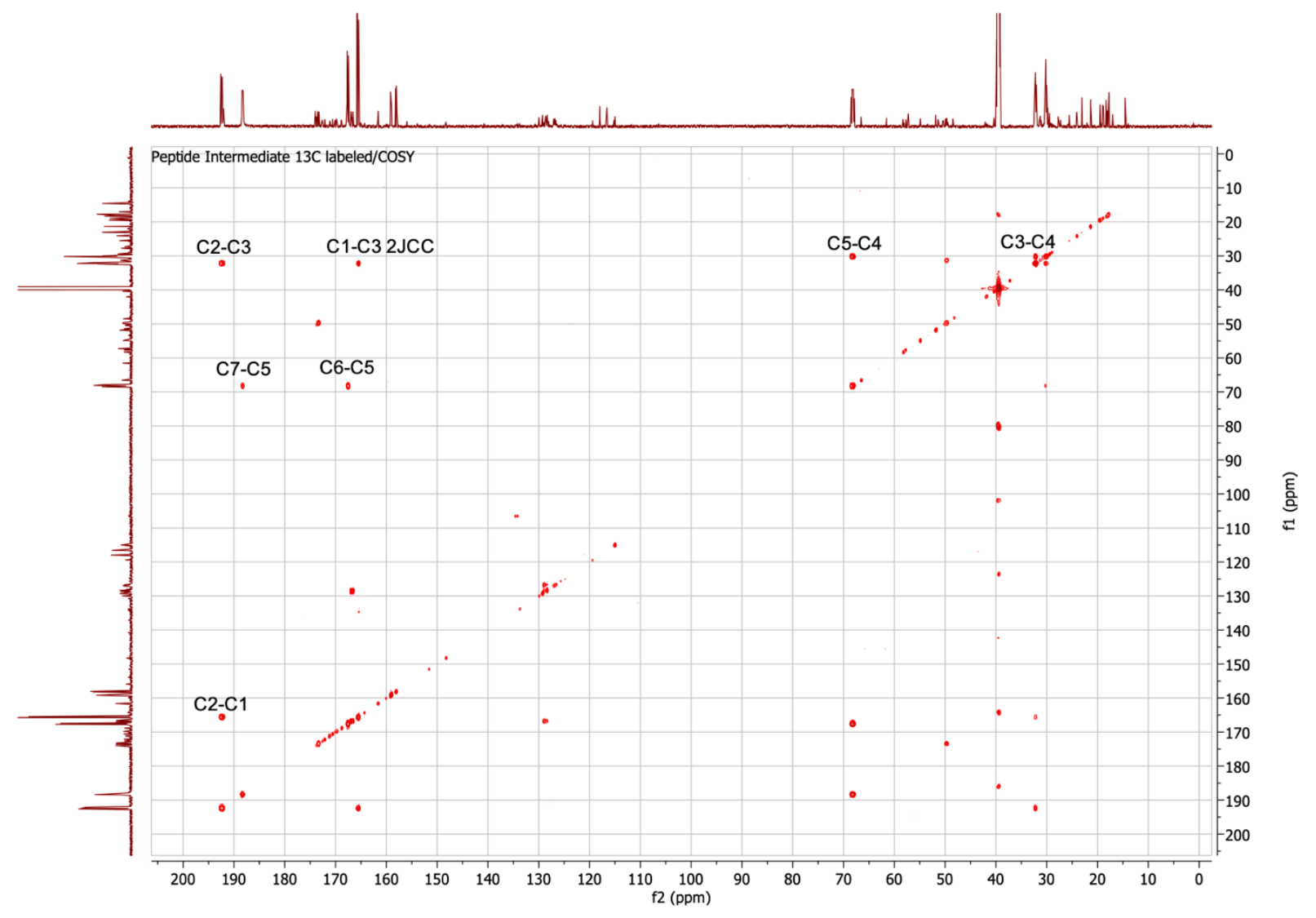

